\title{
6. ESCANABA TROUGH: CENTRAL HILL (SITE 1038) ${ }^{1}$
}

\author{
Shipboard Scientific Party²
}

\section{HOLE 1038A}

Position: $41^{\circ} 00.0163^{\prime} \mathrm{N}, 127^{\circ} 29.6851^{\prime} \mathrm{W}$

Date occupied: 2 October 1996

Date departed: 3 October 1996

Time on hole: $27 \mathrm{hr}, 15 \mathrm{~min}$

Bottom felt (drill pipe measurement from rig floor, $\mathbf{m}$ ): 3233.5

Distance between rig floor and sea level (m): 11.8

Water depth (drill pipe measurement from sea level, m): 3221.8

Total depth (from rig floor, m): 3348.0

Number of cores (including cores having no recovery): 12

Total core recovered (m): 2.65

Core recovery $(\%): 2.3$

Oldest sediment cored:

Depth (mbsf): 114.5

Nature: sandstone

\section{HOLE 1038B}

\section{Position: $41^{\circ} 00.0247^{\prime} \mathrm{N}, 127^{\circ} 29.8707^{\prime} \mathrm{W}$}

Date occupied: 3 October 1996

Date departed: 4 October 1996

Time on hole: $20 \mathrm{hr}, 30 \mathrm{~min}$

Bottom felt (drill pipe measurement from rig floor, m): 3266.0

Distance between rig floor and sea level (m): 11.8

Water depth (drill pipe measurement from sea level, m): 3254.3

Total depth (from rig floor, m): 3386.5

Number of cores (including cores having no recovery): 13

Total core recovered (m): 13.8

Core recovery $(\%): 11.5$

Oldest sediment cored:

Depth (mbsf): 120.5

Nature: sandstone and claystone

\section{HOLE 1038C}

Position: $41^{\circ} 00.1816^{\prime} \mathrm{N}, 127^{\circ} 29.6037^{\prime} \mathrm{W}$

Date occupied: 4 October 1996

${ }^{1}$ Fouquet, Y Zierenberg, R. A., Miller, D J, et al, 1998. Proc. ODP, Init. Repts, 169: College Station, TX (Ocean Drilling Program).

${ }^{2}$ Shipboard Scientific Party is given in the list preceding the Table of Contents.
Date departed: 5 October 1996

Time on hole: $12 \mathrm{hr}, 15 \mathrm{~min}$

Bottom felt (drill pipe measurement from rig floor, m): 3239.0

Distance between rig floor and sea level (m): 11.8

Water depth (drill pipe measurement from sea level, m): 3227.2

Total depth (from rig floor, m): 3280.8

Number of cores (including cores having no recovery): 4

Total core recovered $(\mathbf{m}): 3.16$

Core recovery $(\%): 7.6$

Oldest sediment cored:

Depth (mbsf): 41.8

Nature: altered clay

\section{HOLE 1038D}

Position: $41^{\circ} 00.1441^{\prime} \mathrm{N}, 127^{\circ} 29.6146^{\prime} \mathrm{W}$

Date occupied: 5 October 1996

Date departed: 5 October 1996

Time on hole: $10 \mathrm{hr}, 30 \mathrm{~min}$

Bottom felt (drill pipe measurement from rig floor, m): 3237.0

Distance between rig floor and sea level (m): 11.8

Water depth (drill pipe measurement from sea level, m): 3225.2

Total depth (from rig floor, $\mathbf{m}$ ): 3280.8

Number of cores (including cores having no recovery): 4

Total core recovered $(\mathbf{m}): 3.23$

Core recovery $(\%): 7.4$

Oldest sediment cored:

Depth (mbsf): 43.8

Nature: sand and silty clay

\section{HOLE 1038E}

Position: $41^{\circ} 00.0012^{\prime} \mathrm{N}, 127^{\circ} 29.6463^{\prime} \mathrm{W}$

Date occupied: 5 October 1996

Date departed: 6 October 1996

Time on hole: $8 \mathrm{hr}, 30 \mathrm{~min}$

Bottom felt (drill pipe measurement from rig floor, m): 3221.0

Distance between rig floor and sea level (m): 11.8

Water depth (drill pipe measurement from sea level, $\mathbf{m}$ ): 3209.2

Total depth (from rig floor, m): 3261.6

Number of cores (including cores having no recovery): 4 
Total core recovered (m): 2.41

Core recovery (\%): 5.9

Oldest sediment cored:

Depth (mbsf): 40.6

Nature: siltstone

\section{HOLE 1038F}

Position: $40^{\circ} 59.7304^{\prime} \mathrm{N}, 127^{\circ} 29.2877^{\prime} \mathrm{W}$

Date occupied: 6 October 1996

Date departed: 6 October 1996

Time on hole: $17 \mathrm{hr}, 30 \mathrm{~min}$

Bottom felt (drill pipe measurement from rig floor, m): 3252.0

Distance between rig floor and sea level (m): 11.8

Water depth (drill pipe measurement from sea level, m): 3240.2

Total depth (from rig floor, m): 3290.4

Number of cores (including cores having no recovery): 4

Total core recovered $(\mathrm{m}): 6.62$

Core recovery $(\%): 17.2$

Oldest sediment cored:

Depth (mbsf): 38.4

Nature: silty claystone, clayey siltstone

\section{HOLE 1038G}

Position: $40^{\circ} 59.7255^{\prime} \mathrm{N}, 127^{\circ} 29.2865^{\prime} \mathrm{W}$

Date occupied: 6 October 1996

Date departed: 8 October 1996

Time on hole: 1 day, $13 \mathrm{hr}, 30 \mathrm{~min}$

Bottom felt (drill pipe measurement from rig floor, m): 3251.0

Distance between rig floor and sea level (m): 11.8

Water depth (drill pipe measurement from sea level, m): 3239.2

Total depth (from rig floor, m): 3398.0

Number of cores (including cores having no recovery): 16

Total core recovered $(\mathbf{m}): 44.88$

Core recovery $(\%): 30.5$

Oldest sediment cored:

Depth (mbsf): 144.5

Nature: medium-grained sand

Hard rock:

Depth (mbsf): 147.0

Nature: basalt

\section{HOLE 1038H}

Position: $41^{\circ} 00.0054^{\prime} \mathrm{N}, 127^{\circ} 29.6533^{\prime} \mathrm{W}$

Date occupied: 8 October 1996

Date departed: 9 October 1996

Time on hole: 1 day, $6 \mathrm{hr}, 45 \mathrm{~min}$.

Bottom felt (drill pipe measurement from rig floor, $\mathbf{m}$ ): 3234.0

Distance between rig floor and sea level (m): 11.8
Water depth (drill pipe measurement from sea level, $\mathbf{m}$ ): 3222.2

Total depth (from rig floor, m): 3426.8

Number of cores (including cores having no recovery): 20

Total core recovered (m): 29.99

Core recovery (\%): 15.6

Oldest sediment cored:

Depth (mbsf): 187.9

Nature: claystone

Hard Rock:

Depth (mbsf): 192.8

Nature: basalt

\section{HOLE 1038I}

Position: $40^{\circ} 059.8831^{\prime} \mathrm{N}, 127^{\circ} 29.5639^{\prime} \mathrm{W}$

Date occupied: 9 October 1996

Date departed: 12 October 1996

Time on hole: 3 days, $3 \mathrm{hr}, 15 \mathrm{~min}$

Bottom felt (drill pipe measurement from rig floor, $\mathbf{m}$ ): 3227.0

Distance between rig floor and sea level (m): 11.8

Water depth (drill pipe measurement from sea level, m): 3215.2

Total depth (from rig floor, m): 3631.0

Number of cores (including cores having no recovery): 43

Total core recovered (m): 191.13

Core recovery $(\%): 47.3$

Oldest sediment cored:

Depth (mbsf): 403.4

Nature: claystone

Hard Rock:

Depth (mbsf): 404.0

Nature: basalt

Principal results: A transect of holes (Holes 1038A through 1038I) was made in the vicinity of Central Hill; the highest priority was to drill through the massive sulfide deposits and into the alteration zone near the center of the hydrothermal upflow zone. A primary objective was to establish the causes of the major compositional differences between the deposits at Middle Valley and Escanaba Trough. A series of shallow rotary core barrel (RCB) exploratory holes was targeted primarily on the exposed mounds of massive sulfide to establish the extent, composition, and drillability of the massive sulfide in this area before starting a deeper drill hole.

Massive sulfide recovered from Central Hill suggests that the mineralization forms only a thin (5-15 m) veneer over the sediment sequence. No major massive sulfides were recovered. In addition, the absence of a well-developed, sulfide-veined feeder zone in the sediments under the sulfide mounds suggests relatively pervasive circulation and a diffuse venting of hot fluid over a short period of time rather than a long-lived, focused high-temperature discharge. This agrees with the lack of chimneys and the widespread occurrence of high-temperature pyrrhotite crusts on the sediment observed during submersible dives. Massive sulfides consist predominantly of massive pyrrhotite and vuggy pyrite. Sphalerite is locally abundant and is associated with pyrrhotite.

Of the eight lithologic units identified at the Escanaba Trough Reference Site (Hole 1037B), only Units II, III, and VIII can be identified with any degree of certainty at Site 1038, and these correlations require shorebased sediment analysis before they are confirmed. Using grain-size and magnetic susceptibility data, a correlation can be made between the upper $100 \mathrm{~m}$ of cores in Holes 1038A, 1038B, 1038G, 1038I, and the reference 
hole (1037B); below 100 meters below seafloor (mbsf), stratigraphic correlation becomes more tenuous. Hole 1038I represents our most complete lithostratigraphic sequence at Site 1038.

Near-surface sands lack lateral continuity, suggesting that they may have been derived locally from slump off the steep fault scarps that surround the basin. These sands are correlated to Unit II (Cores 169-1038I$1 \mathrm{X}$ through 9X, 0-75.9 mbsf), which is characterized as graded beds of fine-grained sand to silt and clay interbedded with thin hemipelagic mudstone. Unit III (Cores 169-1038I-9X through 12X, 75.9-103.7 mbsf) is the most correlative horizon to the reference hole. The top of Unit III is characterized by a change from thinly interbedded sandy and silty turbidites and hemipelagic strata to thicker, more sand-rich turbidites separated by relatively thinner mudstone intervals. The top of this interval is identified in all holes that penetrated to a depth in excess of $80 \mathrm{mbsf}$ and may be correlative to the top of the regional seismic transparent layer. Despite the fact that there is $\sim 40 \mathrm{~m}$ of relief between Holes 1038B and 1038I, the top of Unit III occurs within $4.1 \mathrm{~m}$ of the same depth below the seafloor in all the holes. This implies that the topographic expression of the Central Hill is very young. Because of poor recovery, it is difficult to correlate the lower part of the sedimentary sequence (Units IV-VIII) underlying Central Hill with the sequence drilled at the Escanaba Trough Reference Site (Site 1037), $5 \mathrm{~km}$ to the south.

A basalt layer ranging from 2 to at least $5 \mathrm{~m}$ thick was intersected in three holes $(1038 \mathrm{G}, 1038 \mathrm{H}$, and 1038I) at intervals occurring at approximately the same depth below seafloor. This unit may be either a sill or a flow erupted over sediment. The basalt intersection in the base of Hole 1038I (Core 169-1038I-43X, 403.2-404 mbsf) maybe a flow, based on the presence of fresh glass, but it does have a narrow $(2 \mathrm{~mm})$ baked sediment contact at the upper surface. There is, however, insufficient penetration into this interval to ascertain the nature of the unit.

Most samples examined from Site 1038 contain very few foraminifers or are barren. Their alteration is clearly associated with thermal and hydrothermal effects. Hole $1038 \mathrm{~F}$ provides confirmation that Holocene sedimentation is exceptionally fast, probably in excess of $290 \mathrm{~cm} / \mathrm{k} . \mathrm{y}$.

Pore-water fluids collected from Site 1038 show a wide range in chemical compositions. A hydrothermal component is obvious in all the holes and dominates pore-fluid chemistry at shallow depths below hydrothermally active and inactive sulfide mounds. The $\mathrm{Cl}$ concentration ranges from 300 to $800 \mathrm{mM}$, indicating the presence of hydrothermal fluid affected by phase separation. In most holes, the high salinity component dominates pore fluids. Low salinity is particularly evident in sand-rich layers in Holes $1038 \mathrm{~A}, 1038 \mathrm{H}$, and 1038I. This suggests a preferential vapor loss and migration through sand layers after boiling. Pore-fluid compositions also appear to be modified by anhydrite dissolution, Mg-metasomatism, and chlorite formation.

Hole 1038I allowed the recovery of pore fluid from deeper in the section. The thermal gradient in the upper part of Hole $1038 \mathrm{I}$ is $\sim 2^{\circ} \mathrm{C} / \mathrm{m}$. High temperature results in concentrations of $\mathrm{Li}$ and $\mathrm{B}$ below $300 \mathrm{mbsf}$ that are far higher than those recorded in Hole 1037B. Furthermore, the concentration of $\mathrm{Mg}$ declines far more rapidly with depth than at the Escanaba Trough Reference Site, supporting hydrothermal alteration of the sediment. There is a marked change in the composition of pore-fluid chemistry in the sand layer of lithologic Unit III. $\mathrm{Ca}, \mathrm{Cl}, \mathrm{Mg}, \mathrm{Sr}$, and $\mathrm{Na} / \mathrm{Cl}$ ratios decrease, whereas $\mathrm{Li}, \mathrm{B}, \mathrm{K}$, and $\mathrm{NH}_{4}$ concentrations increase. This is consistent with the lateral flow of a hydrothermal component with low $\mathrm{Cl}$ through the sand layer. This fluid acquired high concentrations of $\mathrm{Li}, \mathrm{B}$, $\mathrm{K}$, and $\mathrm{NH}_{4}$ by reaction with sediment. Fluid with similar composition was sampled at Holes 1038A and $1038 \mathrm{H}$, and the low $\mathrm{Cl}$ concentration is related to phase segregation following boiling. High salinity fluids were recovered from sediment beneath a thin basalt layer penetrated at 161 mbsf in Hole 1038I. These fluids could be conjugate brines to the low salinity fluids sampled in the overlying sediment intervals, thus indicating that phase separation has occurred at the upper part of the hydrothermal system.

High methane concentration in gas was found in Holes 1038E, 1038H, 1038F, 1038G, and 1038I. Except for Hole 1038I, drilled away from the hydrothermal field, methane in the cores recovered has a thermogenic origin. The presence of benzene and toluene confirm the high-temperature cracking of organic matter. Bitumen fluorescence also indicates a high maturation temperature of $150^{\circ}-250^{\circ} \mathrm{C}$. The estimated temperature of organic maturation is higher than in Middle Valley. The full range of maturity is observed. Hydrothermal petroleum occurs in the shallow section of several holes. The regional maturation of organic matter has been rapid for all holes. In Hole 1038I, methane has a biogenic origin at shallow levels and a thermogenic origin deeper in the section. Hydrocarbon compositions reflect the terrigenous source of organic matter in the sediments deposited in Escanaba Trough.

\section{INTRODUCTION \\ Geographical Setting}

Escanaba Trough, the area where Central Hill and Holes 1038 through 1038I are located (Fig. 1), forms the southern segment of the Gorda Ridge (Fig. 1A, "Introduction" chapter, this volume). The northern end of the axial valley is only a few kilometers wide, but it widens to $\sim 18 \mathrm{~km}$ at the southern end (Fig. 9, "Introduction" chapter, this volume). The spreading rate is $2.4 \mathrm{~mm} / \mathrm{yr}$ (Atwater and Mudie, 1973), and the valley has a typical slow-spreading ridge morphology. The steep walls on the flank of the valley rise from 900 to $1500 \mathrm{~m}$ above the valley floor. The depth of the axial valley is generally greater than $3300 \mathrm{~m}$ except between $41^{\circ} 17^{\prime}$ and $41^{\circ} 28^{\prime} \mathrm{N}$, where the depth shallows to $<3250 \mathrm{~m}$. Escanaba Trough is divided into two 80to $100-\mathrm{km}$ long segments separated by a $5-\mathrm{km}$, right-lateral offset at $41^{\circ} 08^{\prime} \mathrm{N}$.

South of $41^{\circ} 17^{\prime} \mathrm{N}$, most of the valley is covered by interbedded hemipelagic and turbiditic sediments (Vallier et al., 1973; Clague and Holmes, 1987; Normark et al., 1994). At the southern end, the sedi-

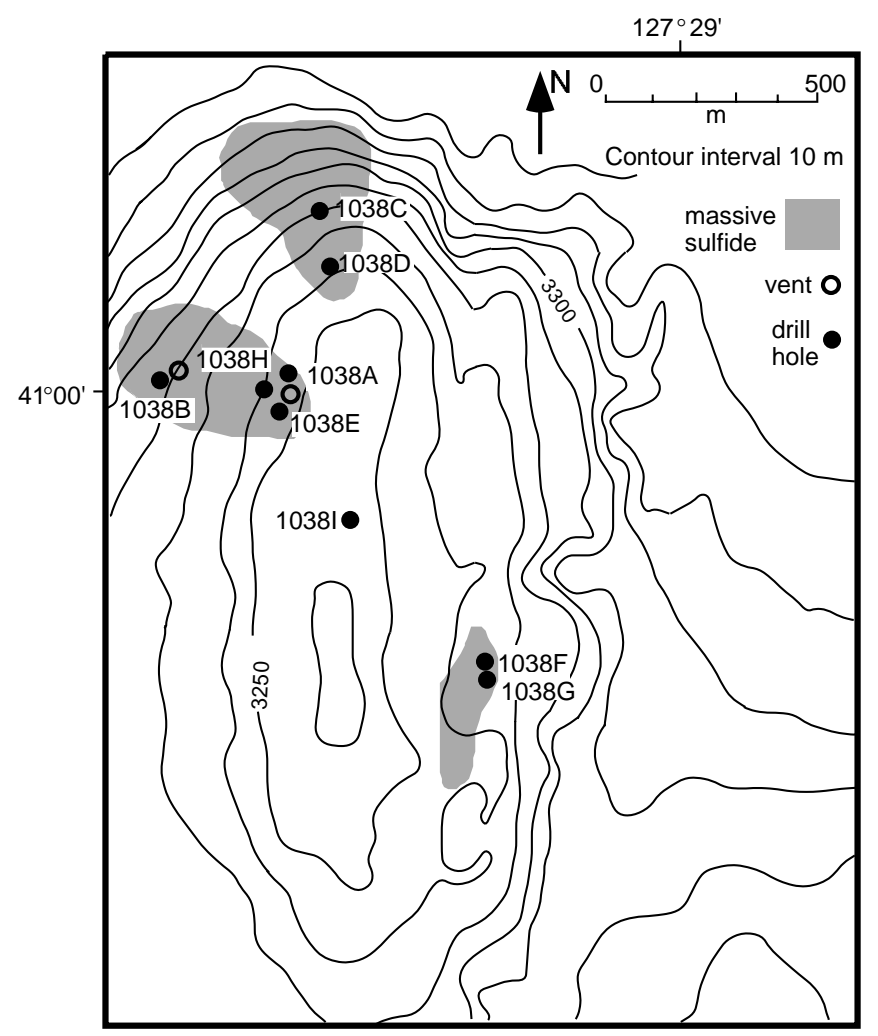

Figure 1. Location map showing the nine holes drilled at Central Hill, and the extent of massive sulfide on the seafloor. 
Figure 2. Schematic diagram showing the uplift of one of the small, circular, sediment hills above a laccolith. The number of sills increases with depth such that there is a transitional boundary between sediment and the upper part of the oceanic crust, which is interpreted to be a sheeted sill complex. Faults that bound the uplifted sediment hill provide a high-permeability pathway for basaltic dikes that feed lava flows and for hydrothermal fluids that form massive sulfide deposits. High-permeability sandy turbidite layers may also channel hydrothermal fluids and are likely sites of subsurface mineralization (Zierenberg et al., 1993).

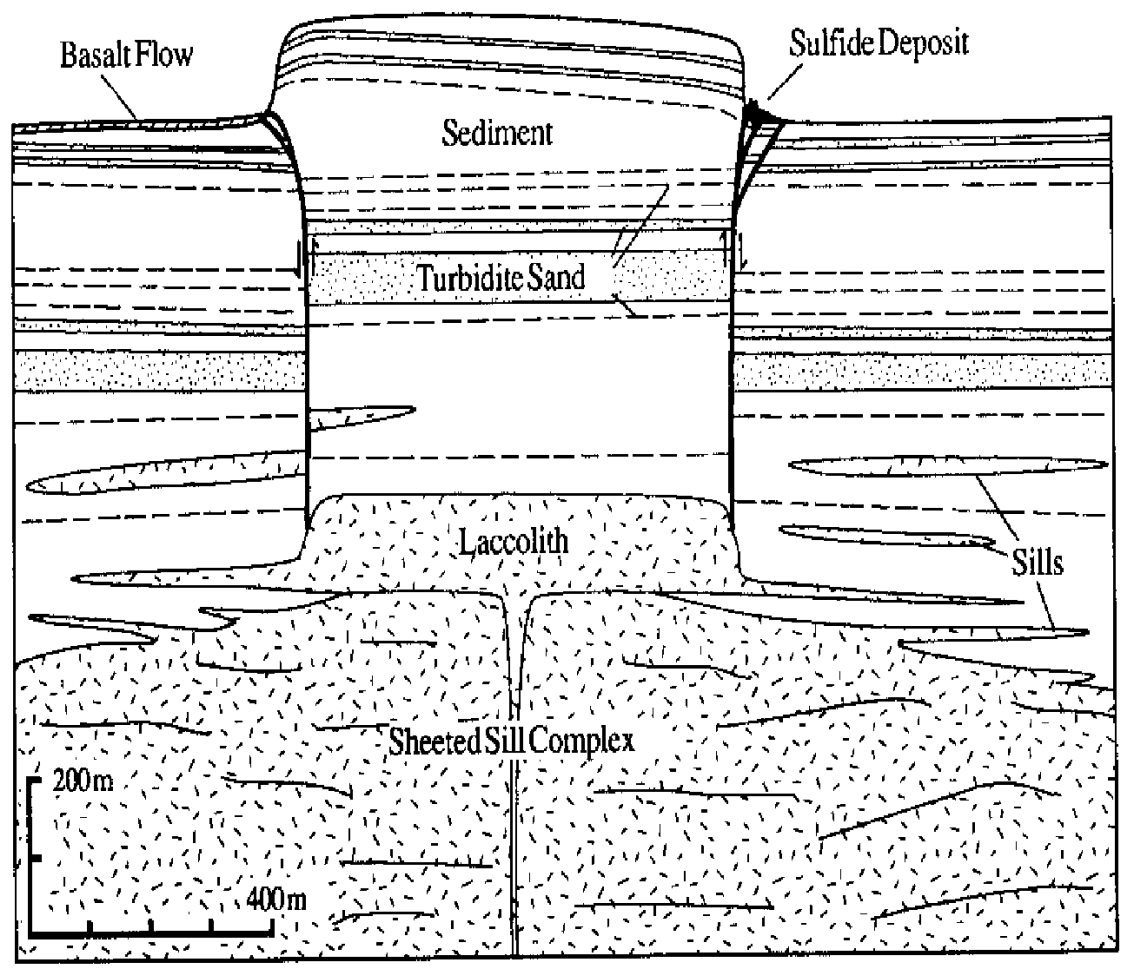

hills form by inflation of basaltic sills near the sediment/basement interface (Denlinger and Holmes, 1994). The faults that bound the uplifted sediment hills provided conduits for hydrothermal fluids and, in some localities, may also have provided a pathway for basalt to erupt at the surface (Fig. 2; Ross and Zierenberg, 1994). A mass and thermal balance geophysical model demonstrates that sufficient heat is available from these postulated intrusions to produce massive sulfide deposits in the million ton size range (Davis and Becker, 1994).

\section{Central Hill}

At the latitude of Central Hill, the Escanaba Trough is filled with $\sim 600 \mathrm{~m}$ of sediment (Zierenberg et al., 1994). Acoustic reflections from volcanic basement are, however, not well developed below the central zone of disrupted sediment, so the depth of the basement is poorly constrained and could be a transitional zone of alternating basaltic sills and sediments.

Central Hill is one of the numerous small, uplifted sediment hills that characteristically occur above the larger igneous complexes that punctuate the sediment-filled rift axis in the Escanaba Trough (Morton et al., 1987). Central Hill (1 km in diameter and $60 \mathrm{~m}$ high) is steep-sided, formed of uplifted sediment, and interpreted as a cylindrical block of sediment bordered by curvilinear normal faults, that probably was uplifted by the intrusion of large basaltic sill.

\section{Tectonic Activity}

The sediment-covered western side of Central Hill is bounded on the north and west by a series of stepped scarps (Fig. 3), each a few meters high (Ross et al., 1996), which contrasts with the large masswasting scarps that bound most of the sediment hills. Central Hill appears to be a morphologically younger feature than most of the similar-sized sediment hills and clearly has not been affected by mass wasting to the same extent as the nearby, presumably older, Southwest Hill. Uplift of the northern part of the hill was accommodated by a series of stepped normal faults downdropped to the north. The 


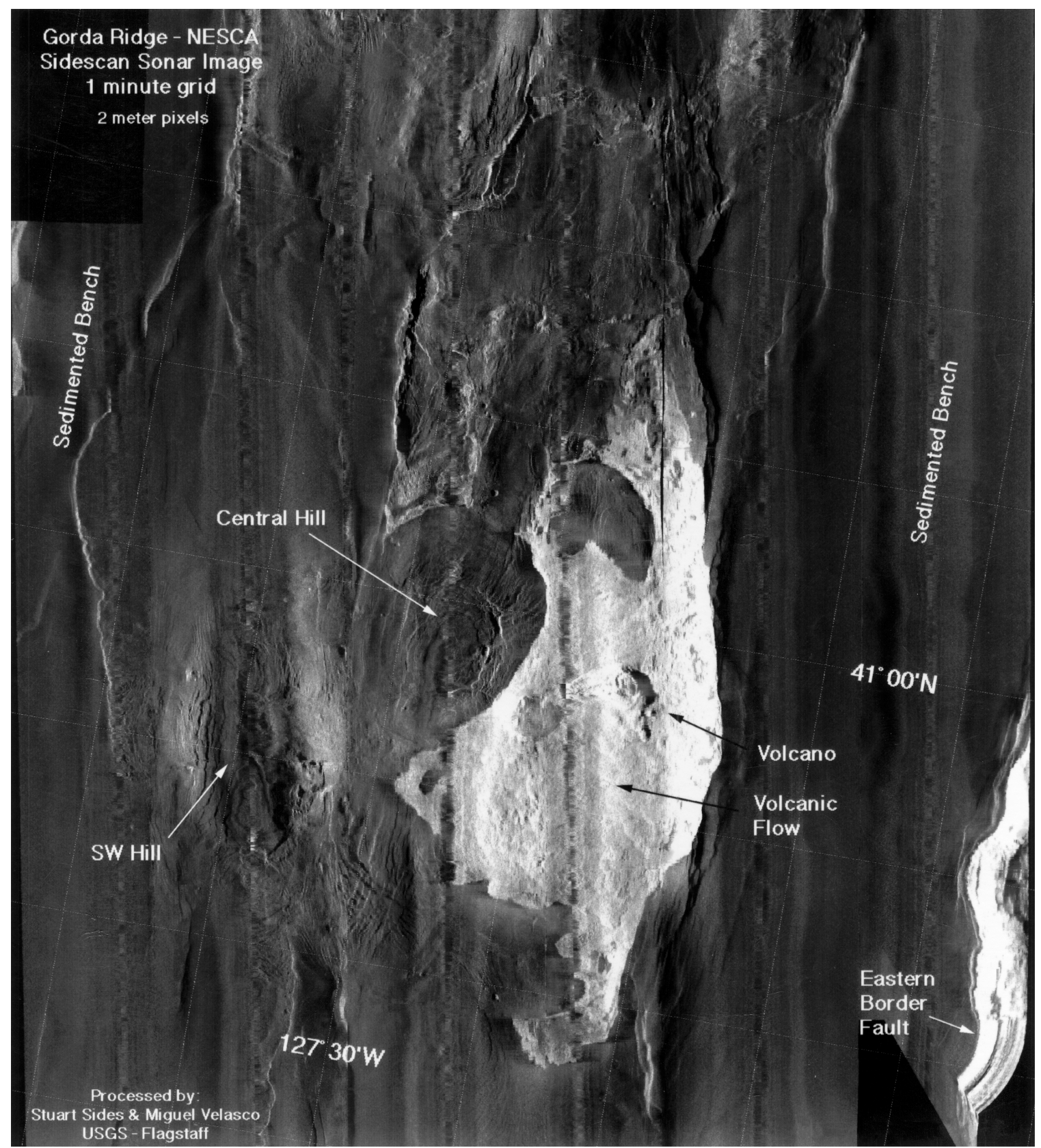

Figure 3. AMS $60 \mathrm{kHz}$ side-scan sonar image of Central Hill (Ross et al., 1996). The sonar was towed $250 \mathrm{~m}$ above seafloor, providing an $~ 2.5-\mathrm{km}$ swath. White areas (high reflectivity) to the east of Central Hill are pillow and lobate lava flows erupted at the surface of the sediment, probably from the volcanic high visible at the center of the white area. The western wall of the hill is clearly fault dominated, whereas the northeastern and eastern part are subject to mass wasting and channeling.

western and eastern flank are also formed by sediment-covered scarps that may represent normal faults. The eastern flank of the hill is an area of complex bottom morphology, including graben-like depressions and collapsed areas that control the sulfide deposit (Zierenberg et al., 1994). Channels, presumably incised by mass wasting, cut the sediment along the steeper northern and eastern sides of the hill (Fig. 3).

\section{Volcanic Activity}

A large exposure of glassy basalt pillows occurs at the surface of the flat sediment fill east of the crest of Central Hill (Figs. 10-12, "Introduction" chapter, this volume; Ross and Zierenberg, 1994). The erup- tion of these surface volcanic rocks is probably related to the uplift of the sediment hills (Ross and Zierenberg, 1994). Lava tubes drape the north flank of the hill indicating flow to the north. These lava tubes fed sheet-flow basalts that ponded within the central depression of the spreading center. Basalt flows have not been observed on any of the sediment scarps (Zierenberg et al., 1994). High-resolution sonar images clearly show the surface extent of the recent lava flows on the eastern side of the hill (Fig. 3; Ross et al., 1996).

\section{Hydrothermal Deposits}

The western, sediment-covered part of Central Hill contains the most extensive sulfide deposits observed in Escanaba Trough (Fig. 


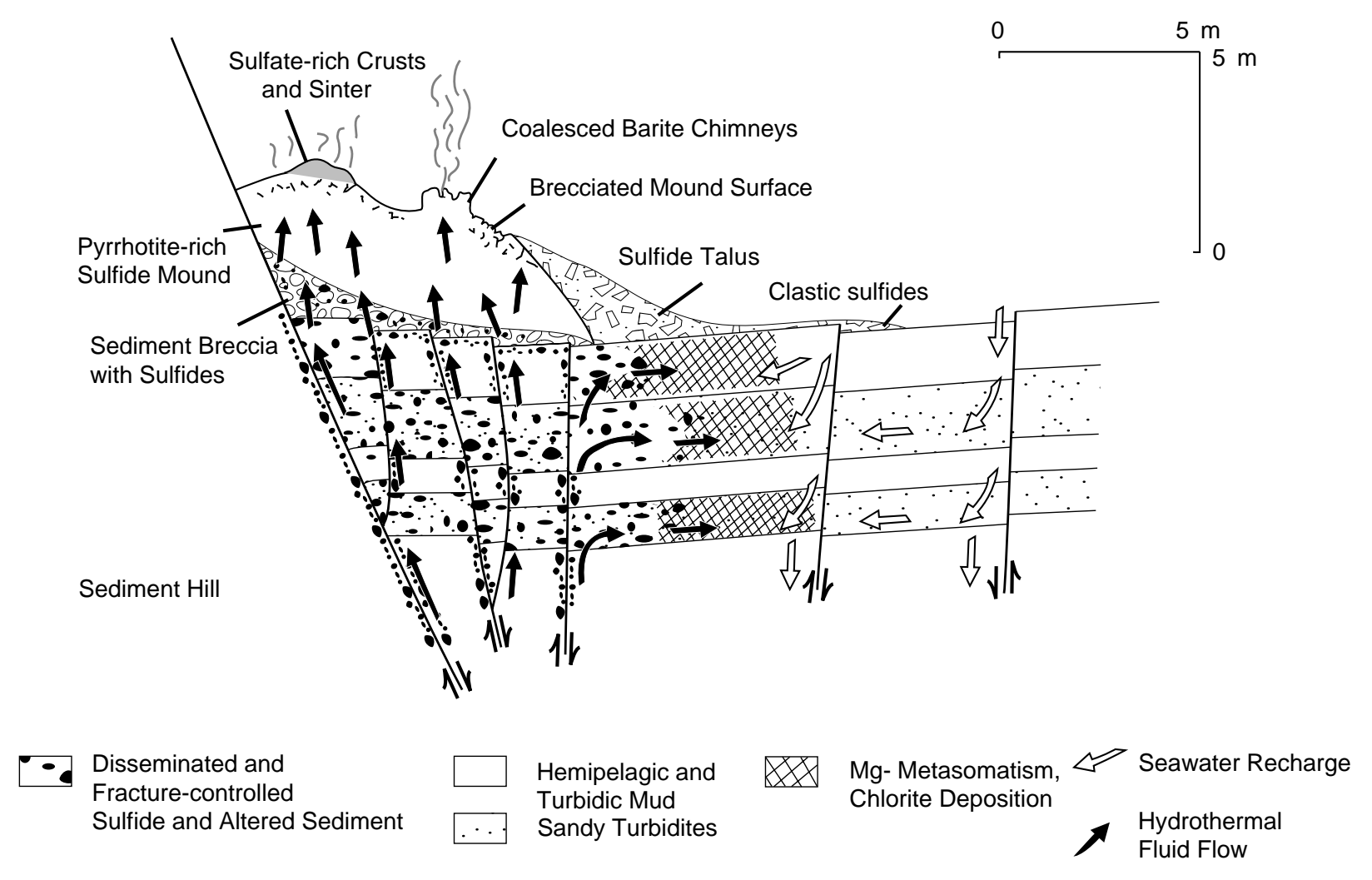

Figure 4. Generalized model for hydrothermal discharge and deposition of sulfide mounds at the margin of an uplifted sediment hill. The evolution of a sulfide mound includes initial precipitation of sulfate crust and chimneys, main-stage deposition of the pyrrhotite-rich sulfide assemblage below the sulfate carapace, inflationary growth during ongoing cementation, recrystallization and replacement within the mound, brecciation and degradation of the mound by mass wasting, and renewed precipitation of sulfate and sulfide from fluids discharging through the mound surface. The bounding fault structure and sediment breccia deposits provide cross-stratal permeability for hydrothermal fluids. Fluids migrate laterally along porous sandy units in the turbidite section. Subsurface mixing of hydrothermal fluid and seawater along faults and within permeable beds results in disseminated and fracture-controlled sulfide mineralization, $\mathrm{Mg}$ metasomatism, and chlorite formation in the sediment (Zierenberg et al., 1993).

12, "Introduction" chapter, this volume; Fig. 4). Three areas of outcropping massive sulfide mineralization were explored during 10 submersible dives. High-resolution sonar shows increasing backscatter in the areas of outcropping sulfides (Fig. 3). The massive sulfide deposits on the west and southeast flanks of Central Hill (Fig. 12, "Introduction" chapter, this volume) are actively venting hydrothermal fluid, and the area on the northern flank shows indications of very recent hydrothermal activity, suggesting that these deposits are all part of the same hydrothermal system. An extensive area of massive sulfide is exposed on the north slope of Central Hill. Massive sulfide extends more than $270 \mathrm{~m}$ from north to south and more than $100 \mathrm{~m}$ from east to west, but the western edge of the deposit has not been defined with certainty. Within this area, there is a nearly continuous outcrop of massive sulfide with few sediment-covered areas. The best explored and most hydrothermally active area of sulfide mineralization on the Central Hill extends west from the northern end of the sediment-covered hill top (Fig. 10, "Introduction" chapter, this volume). This is not an area of continuous sulfide outcrop, but rather a region of abundant, closely spaced sulfide mounds. The mounds are typically $20-60 \mathrm{~m}$ in diameter and $5-10 \mathrm{~m}$ high. Two mounds were observed actively discharging high-temperature hydrothermal fluid in 1988; one near the eastern margin of the sulfide area was venting $217^{\circ} \mathrm{C}$ fluid, and one on the western edge of the explored area was venting $108^{\circ} \mathrm{C}$ fluid (Fig. 12, "Introduction" chapter, this volume). End-member fluid composition is identical at the two sites, indicating that this large hydrothermal field is hydrologically interconnected at depth (Campbell et al., 1994). By 1994, the $217^{\circ} \mathrm{C}$ vent had cooled to $\sim 65^{\circ} \mathrm{C}$ (R. Lutz, pers. comm., 1994). The collected fluids therefore likely reflect the waning phase of hydrothermal activity accompanying the cooling of the magmatic source.

\section{Hydrothermal Fluids}

Escanaba Trough hydrothermal fluid is slightly alkaline and has a chlorinity $20 \%$ higher than seawater. The relatively low temperature and high $\mathrm{pH}$ result in a very low concentration of metal in the endmember fluid (Campbell et al., 1994). Chemical and isotopic composition of the fluids requires extensive interaction with sediment (Böhlke and Shanks, 1994). Strontium-isotope composition (0.7099; Campbell et al., 1994) and high-Sr concentration appears to be controlled by complete reequilibration with the local sediment (Sr-isotopic composition: 0.7093-0.7126; German et al., 1995). Any basaltic component to the Sr-isotopic composition is completely obscured by sediment/fluid interaction.

Reaction of high-temperature, acidic fluids with sediments could extract significant quantities of metals and may explain high As, Bi, $\mathrm{Pb}$, and $\mathrm{Sb}$ concentrations in Escanaba Trough sulfides (Koski et al., 1994). However, the Escanaba deposits cannot be formed by the metal-depleted fluid currently venting. The active vents are depositing predominantly anhydrite, accompanied by minor amounts of barite, $\mathrm{Mg}$-smectite, and sulfide minerals. Inactive barite and sulfide chimneys occur at the top of some mounds, but chimneys are not common. 


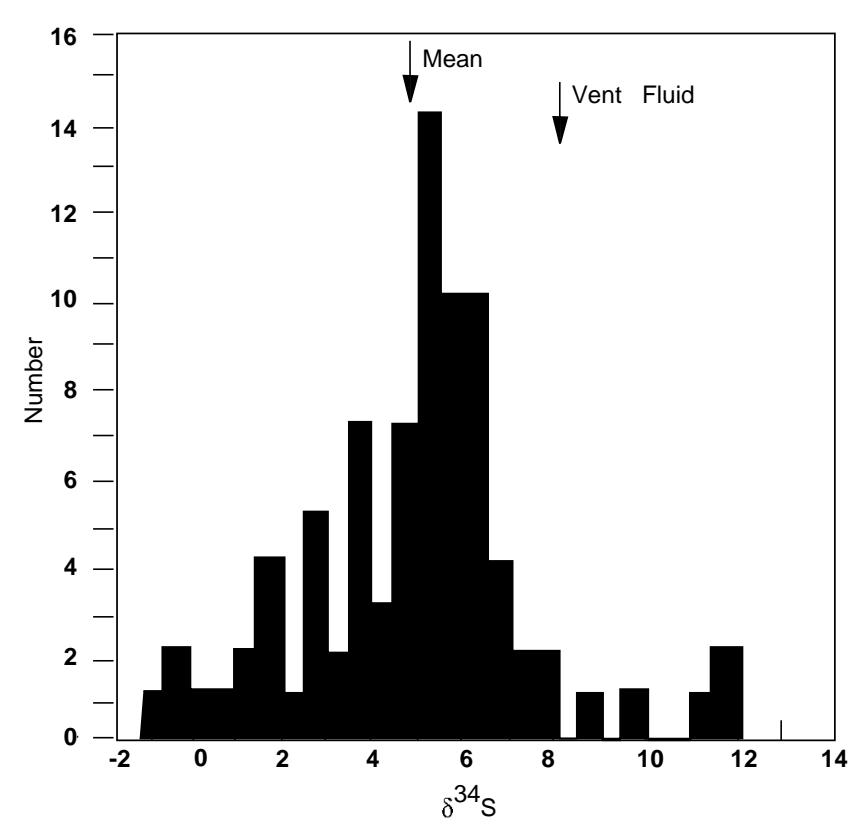

Figure 5. Histogram of $\delta^{34} \mathrm{~S}$ values for sulfide from the Escanaba Trough. The mean value for sulfide samples $(4.9 \%)$ is distinctly different from that for $\mathrm{H}_{2} \mathrm{~S}$ collected from the vent fluid (7.8\%). Data from Koski et al. (1988), Böhlke and Shanks (1994), Zierenberg and Shanks (1994), and Zierenberg et al. (1993).

Reaction of acidic metal-rich fluid with carbonate in the sediment would lower the acidity, causing metal sulfide precipitates and possibly the formation of massive sulfide deposits at depth (Bowers et al., 1985). The subsurface deposition of metal has been proposed for the Guaymas Basin hydrothermal system and may explain the relatively low levels of dissolved metal in the hydrothermal solutions venting there (Niemitz, 1982; Peter and Scott, 1988). Escanaba Trough sediments contain much lower contents of carbonate and organic carbon, relative to the Guaymas Basin sediments, but subsurface cooling and the deposition of metal sulfide may explain the low concentration in the Escanaba Trough fluid (Campbell et al., 1994). This hypothesis can only be confirmed by drilling.

The Escanaba Trough is similar to the sediment-hosted sulfide deposits at Guaymas Basin and Middle Valley in displaying a range of sulfur isotopic values in sulfide minerals $(-1$ to +12$)$, with average values $\sim 5 \%$ o (Fig. 5). High values are consistent with large proportions of hydrothermal $\mathrm{H}_{2} \mathrm{~S}$ formed by the reduction of seawater sulfate (Zierenberg and Shanks, 1994), whereas negative values may require contributions of biogenic sulfide from the sediment. Isotopic ratios of oxygen, hydrogen, and sulfur in hydrothermal water are consistent with seawater/sediment reactions at temperatures between $220^{\circ}$ and $300^{\circ} \mathrm{C}$, with a ratio of water to rock of $\sim 2$ to 6 (Böhlke and Shanks, 1994).

\section{Sulfide Mineralization}

Sulfide samples collected at the surface of the deposit are rich in pyrrhotite, similar to Middle Valley, with locally abundant isocubanite, sphalerite, marcasite, and barite. Unlike the Middle Valley sulfides, many samples are enriched in gold. Relative to sulfide deposits formed on sediment-free ridges, the samples are enriched in arsenic, bismuth, antimony, lead, and tin that are derived from alteration of sediment in the high-temperature reaction zone at depth. (Zierenberg et al., 1993; Koski et al., 1994).
Sulfide samples recovered from Escanaba Trough typically fall into one of two compositional types (Koski et al., 1994). The first consist of pyrrhotite-rich sulfide mounds, chimneys, and sulfidecemented sedimentary breccia. These samples contain variable amounts of chalcopyrite and isocubanite, and minor sphalerite and löllingite. The second type consists of polymetallic sulfide samples that are less common and are interpreted to form the walls of sulfide chimneys. They are also present as a cement in sandy turbidites. This assemblage contains dominant sphalerite, isocubanite, pyrrhotite, galena, arsenopyrite, and löllingite, with trace amounts of boulangerite, stannite, and franckeite. Sulfate-dominant deposits include bariterich crusts and chimneys, both of which are typically found on top of sulfide mounds.

\section{Hydrothermal Alteration}

Hydrothermal alteration is characterized by the replacement of hemipelagic sediments by $\mathrm{Mg}$-rich chlorite resulting from intense $\mathrm{Mg}$-metasomatism in a mixing zone where hydrothermal fluids interact with seawater and sediment at temperatures above $200^{\circ} \mathrm{C}$. Lower temperature reactions are recorded by changes in surface sediment chemistry and pore-fluid composition (Magenheim and Gieskes, 1994). Oxygen-isotope data from altered sediments suggest that alteration temperatures were between $200^{\circ}$ and $240^{\circ} \mathrm{C}$ (Zierenberg and Shanks, 1994). Based on the dominant mineralogical assemblages in altered rocks collected with sediment cores and submersible, three types of alteration were distinguished (Zierenberg and Shanks, 1994). The first was Mg-Fe smectite, formed by the mixing of hydrothermal fluid with minor amounts of seawater in a mineralized sandy turbidite. Oxygen isotopes indicate formation at $200^{\circ} \mathrm{C}$. The second type of alteration is chloritization, as exemplified in a core with an intensely altered sediment that was completely replaced by hydrothermal clinochlore. The third type, talc and Mg-smectites, occur as minor components in massive sulfide and active vent precipitates. This formed by an extensive mixing of seawater with hydrothermal fluid at temperatures above $200^{\circ} \mathrm{C}$. They probably form by direct precipitation near or above the sediment/water interface by incorporating seawater $\mathrm{Mg}$ with $\mathrm{Si}$ in the hydrothermal fluid.

\section{Scientific Objectives}

A transect of holes (Site 1038) was made across the Central Hill massive sulfide deposit, and the highest priority was to drill through the massive sulfide deposit and into the alteration zone near the center of the hydrothermal upflow zone. Drilling objectives at this site were similar to those at the Bent Hill deposit. One objective was to establish the causes of the major compositional differences between the deposits at Middle Valley and Escanaba Trough. A series of advanced piston corer/extended core barrel (APC/XCB) shallow exploratory holes was targeted primarily at the sediment-covered areas of the seafloor between exposed mounds of massive sulfide to establish the extent, composition, and drillability of the massive sulfide in this area before attempting a deeper, RCB-drilled hole.

\section{OPERATIONS}

Nine holes were drilled in the vicinity of Central Hill as part of an exploration program to determine the lateral and stratigraphic variability of the massive sulfide deposits and underlying sediments on the north and east flanks of the uplifted hill.

\section{Hole 1038A}

The ship moved in dynamic positioning mode from Site 1037 to a position on the north side of Central Hill where markers had been 
Table 1. Site 1038 coring summary.

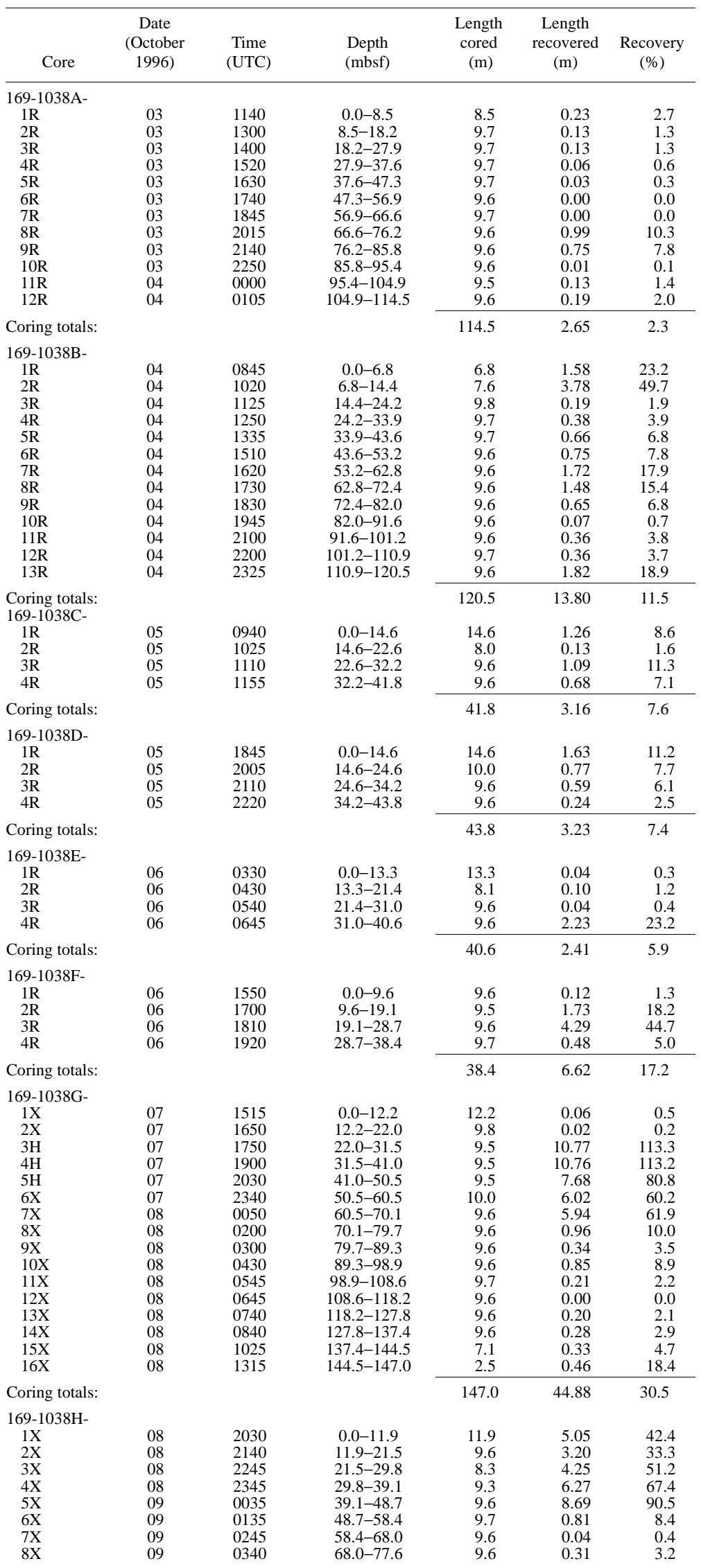


Table 1 (continued).

\begin{tabular}{|c|c|c|c|c|c|c|}
\hline Core & $\begin{array}{c}\text { Date } \\
\text { (October } \\
1996)\end{array}$ & $\begin{array}{l}\text { Time } \\
\text { (UTC) }\end{array}$ & $\begin{array}{l}\text { Depth } \\
\text { (mbsf) }\end{array}$ & $\begin{array}{l}\text { Length } \\
\text { cored } \\
(\mathrm{m})\end{array}$ & $\begin{array}{l}\text { Length } \\
\text { recovered } \\
\text { (m) }\end{array}$ & $\begin{array}{c}\text { Recovery } \\
(\%)\end{array}$ \\
\hline $9 \mathrm{X}$ & 09 & 0445 & $77.6-87.1$ & 9.5 & 0.00 & 0.0 \\
\hline $10 \mathrm{X}$ & 09 & 0600 & $87.1-96.7$ & 9.6 & 0.01 & 0.1 \\
\hline $11 X$ & 09 & 0655 & $96.7-106.3$ & 9.6 & 0.01 & 0.1 \\
\hline $12 \mathrm{X}$ & 09 & 0805 & $106.3-115.9$ & 9.6 & 0.00 & 0.0 \\
\hline $13 \mathrm{X}$ & 09 & 0905 & $115.9-125.6$ & 9.7 & 0.00 & 0.0 \\
\hline $14 \mathrm{X}$ & 09 & 1010 & $125.6-135.2$ & 9.6 & 0.68 & 7.1 \\
\hline $15 X$ & 09 & 1150 & $135.2-144.8$ & 9.6 & 0.11 & 1.1 \\
\hline $16 \mathrm{X}$ & 09 & 1345 & $144.8-154.4$ & 9.6 & 0.24 & 2.5 \\
\hline $17 \mathrm{X}$ & 09 & 1500 & $154.4-164.0$ & 9.6 & 0.00 & 0.0 \\
\hline $18 \mathrm{X}$ & 09 & 1615 & $164.0-173.6$ & 9.6 & 0.05 & 0.5 \\
\hline $19 X$ & 09 & 1740 & $173.6-183.6$ & 10.0 & 0.00 & 0.0 \\
\hline $20 X$ & 09 & 1900 & $183.6-192.8$ & 9.2 & 0.28 & 3.0 \\
\hline Coring totals: & & & & 192.8 & 30.00 & 15.6 \\
\hline \multicolumn{7}{|l|}{ 169-1038I- } \\
\hline $1 \mathrm{X}$ & 10 & 0000 & $0.0-9.3$ & 9.3 & 5.92 & 63.6 \\
\hline $2 X$ & 10 & 0040 & $9.3-17.3$ & 8.0 & 3.72 & 46.5 \\
\hline $3 \mathrm{H}$ & 10 & 0210 & $17.3-26.8$ & 9.5 & 10.54 & 110.9 \\
\hline $4 \mathrm{H}$ & 10 & 0330 & $26.8-36.3$ & 9.5 & 10.08 & 106.1 \\
\hline $5 \mathrm{H}$ & 10 & 0450 & $36.3-45.8$ & 9.5 & 9.98 & 105.0 \\
\hline $6 \mathrm{H}$ & 10 & 0605 & $45.8-55.3$ & 9.5 & 7.93 & 83.5 \\
\hline $7 \mathrm{H}$ & 10 & 0930 & $55.3-64.8$ & 9.5 & 9.94 & 104.0 \\
\hline $8 \mathrm{X}$ & 10 & 1045 & $64.8-74.4$ & 9.6 & 9.83 & 102.0 \\
\hline $9 \mathrm{X}$ & 10 & 1140 & $74.4-84.0$ & 9.6 & 3.81 & 39.7 \\
\hline $10 \mathrm{X}$ & 10 & 1240 & $84.0-93.6$ & 9.6 & 0.28 & 2.9 \\
\hline $11 \mathrm{X}$ & 10 & 1420 & $93.6-103.2$ & 9.6 & 9.25 & 96.3 \\
\hline $12 \mathrm{X}$ & 10 & 1520 & $103.2-112.8$ & 9.6 & 0.51 & 5.3 \\
\hline $13 X$ & 10 & 1610 & $112.8-122.4$ & 9.6 & 0.00 & 0.0 \\
\hline $14 \mathrm{X}$ & 10 & 1700 & $122.4-132.1$ & 9.7 & 0.00 & 0.0 \\
\hline $15 X$ & 10 & 1805 & $132.1-141.7$ & 9.6 & 0.00 & 0.0 \\
\hline $16 X$ & 10 & 1930 & $141.7-151.3$ & 9.6 & 0.33 & 3.4 \\
\hline $17 \mathrm{X}$ & 10 & 2130 & $151.3-160.9$ & 9.6 & 1.61 & 16.8 \\
\hline $18 \mathrm{X}$ & 10 & 2345 & $160.9-170.5$ & 9.6 & 0.39 & 4.1 \\
\hline $19 \mathrm{X}$ & 11 & 0140 & $170.5-180.1$ & 9.6 & 0.87 & 9.1 \\
\hline $20 \mathrm{X}$ & 11 & 0345 & $180.1-189.7$ & 9.6 & 1.21 & 12.6 \\
\hline $21 X$ & 11 & 0515 & $189.7-199.4$ & 9.7 & 1.95 & 20.1 \\
\hline $22 \mathrm{X}$ & 11 & 0705 & $199.4-209.0$ & 9.6 & 0.19 & 2.0 \\
\hline $23 X$ & 11 & 0840 & $209.0-218.6$ & 9.6 & 0.40 & 4.2 \\
\hline $24 X$ & 11 & 1000 & $218.6-228.2$ & 9.6 & 0.01 & 0.1 \\
\hline $25 X$ & 11 & 1220 & $228.2-237.8$ & 9.6 & 0.00 & 0.0 \\
\hline $26 X$ & 11 & 1345 & $237.8-247.4$ & 9.6 & 0.01 & 0.1 \\
\hline $27 \mathrm{X}$ & 11 & 1530 & $247.4-257.1$ & 9.7 & 0.02 & 0.2 \\
\hline $28 \mathrm{X}$ & 11 & 1730 & $257.1-266.7$ & 9.6 & 6.50 & 67.7 \\
\hline $29 X$ & 11 & 2115 & $266.7-276.4$ & 9.7 & 9.19 & 94.7 \\
\hline $30 \mathrm{X}$ & 11 & 2300 & $276.4-286.1$ & 9.7 & 3.38 & 34.8 \\
\hline $31 X$ & 12 & 0105 & $286.1-295.7$ & 9.6 & 7.49 & 78.0 \\
\hline $32 \mathrm{X}$ & 12 & 0310 & $295.7-305.3$ & 9.6 & 4.22 & 43.9 \\
\hline $33 X$ & 12 & 0505 & $305.3-314.9$ & 9.6 & 8.98 & 93.5 \\
\hline $34 X$ & 12 & 0650 & $314.9-324.5$ & 9.6 & 8.87 & 92.4 \\
\hline $35 \mathrm{X}$ & 12 & 0820 & $324.5-334.1$ & 9.6 & 3.85 & 40.1 \\
\hline $36 \mathrm{X}$ & 12 & 1005 & $334.1-343.7$ & 9.6 & 2.53 & 26.3 \\
\hline $37 X$ & 12 & 1135 & $343.7-353.3$ & 9.6 & 9.53 & 99.3 \\
\hline $38 \mathrm{X}$ & 12 & 1310 & $353.3-362.9$ & 9.6 & 2.53 & 26.3 \\
\hline $39 X$ & 12 & 1425 & $362.9-372.5$ & 9.6 & 10.09 & 105.1 \\
\hline $40 X$ & 12 & 1545 & $372.5-382.1$ & 9.6 & 8.03 & 83.6 \\
\hline $41 X$ & 12 & 1740 & $382.1-391.8$ & 9.7 & 6.25 & 64.4 \\
\hline $42 X$ & 12 & 1845 & $391.8-401.4$ & 9.6 & 8.64 & 90.0 \\
\hline $43 X$ & 12 & 2050 & $401.4-404.0$ & 2.6 & 2.27 & 87.3 \\
\hline Coring totals: & & & & 404.0 & 191.13 & 47.3 \\
\hline
\end{tabular}

Note: An expanded version of this coring summary table that includes lengths and depths of sections, location of whole-round samples, and comments on sampling disturbance is included on CD-ROM in the back pocket of this volume.

placed by submersible operations near active hydrothermal vents. This location marks the eastern margin of a broad exposure of massive sulfide on the seafloor. We conducted a short camera survey and initiated Hole 1038A (Table 1) near marker 6X on the flank of a small hydrothermally active sulfide mound using the RCB system under the assumption that massive sulfide would hinder APC/XCB coring. This hole was terminated after penetrating through the massive sulfide and >100 $\mathrm{m}$ into the underlying sediments.

\section{Hole 1038B}

Hole 1038B was sited near the western margin of the same area of massive sulfide exposure through which Hole 1038A was drilled. The position of Hole 1038B was determined by camera survey, and $\mathrm{RCB}$ coring started in massive sulfide exposed at the seafloor. Oper- ations concluded at this hole after penetrating through the massive sulfide and sampling sediment to a depth in excess of $120 \mathrm{mbsf}$.

\section{Holes 1038C and 1038D}

A second area of extensive massive sulfide exposure on the north face of Central Hill was the target of Holes 1038C and 1038D. We used camera surveys to locate both of these targets and terminated RCB drilling in both once we had penetrated through the massive sulfides and to depths of 41.8 and $43.8 \mathrm{mbsf}$, respectively.

\section{Hole 1038E}

This hole was sited $60 \mathrm{~m}$ southeast of Hole 1038A, on the largest mound of massive sulfide in the area. We terminated this hole at 45.5 


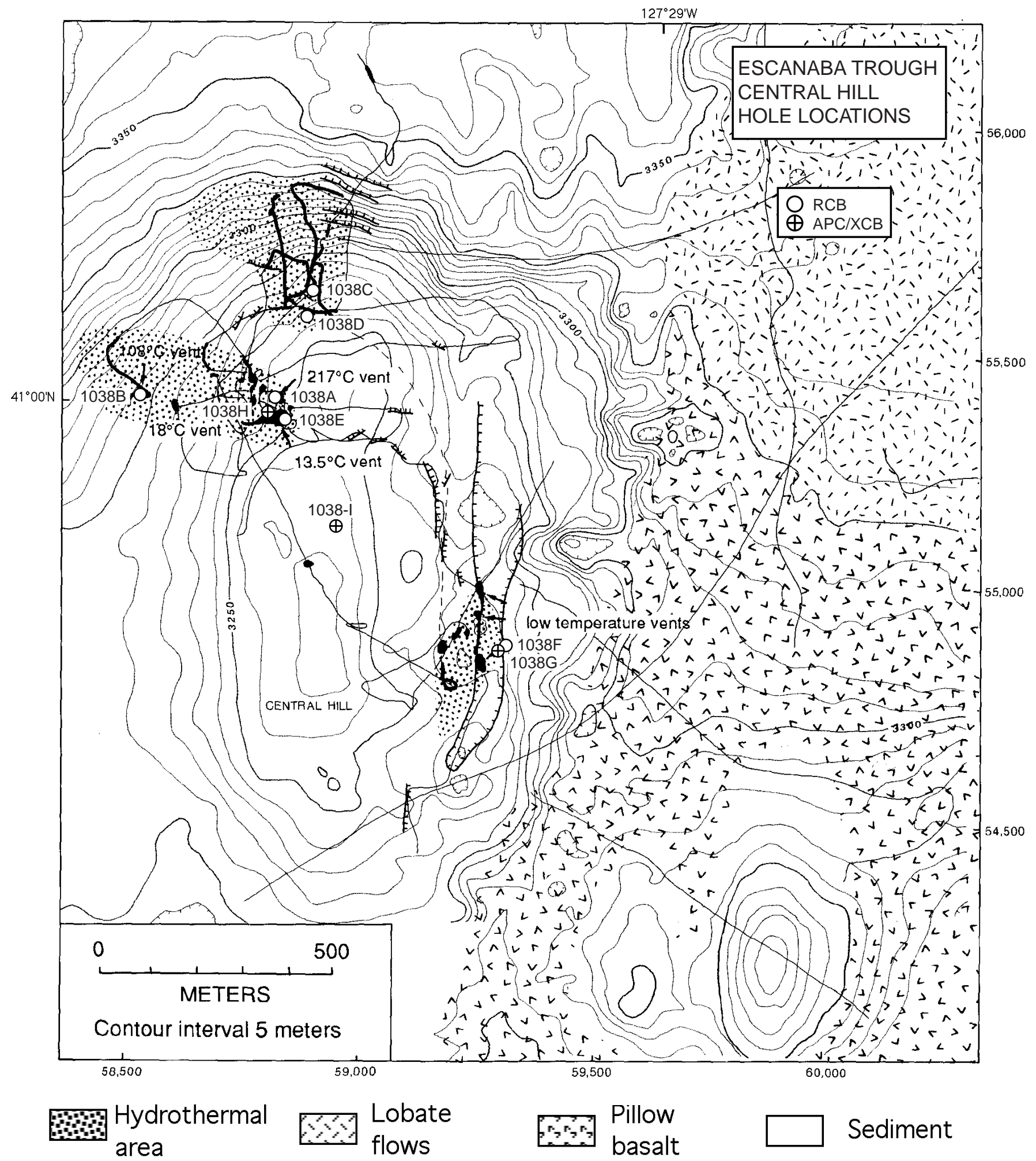

Figure 6. Bathymetric chart showing the location of holes, active vents, and exposed massive sulfide at Site 1038, Central Hill, Escanaba Trough. 
mbsf, after determining the thickness of the massive sulfide deposit at this location.

\section{Hole 1038F}

Another primary target of operations in this exploratory phase of drilling was an exposure of massive sulfide on the eastern side of Central Hill. Using the vibration-isolated television camera, we located an outcrop of massive sulfide in this field and initiated RCB drilling at Hole 1038F. This hole, like those before it, was terminated once we had penetrated through the massive sulfide and into the sediment below to a depth of $38.5 \mathrm{mbsf}$.

\section{Hole 1038G}

Recognizing the potential of and the need for improved recovery at depth, we decided to exchange the RCB system for the standard APC/XCB bottom-hole assembly. Our plan was to overcome the difficulties in penetrating the hard carapace of massive sulfides exposed at the seafloor by initiating holes with the XCB and switching to APC operations once we were into sediments that might yield to piston coring. Hole $1038 \mathrm{G}$ was sited a few meters away from Hole $1038 \mathrm{~F}$ in an area where nearby clam beds indicated probable hydrothermal fluid discharge. Operations at this hole ended when we encountered basalt between 137 and 147 mbsf that the XCB shoe could not effectively penetrate.

\section{Hole 1038H}

Given that all the holes located so far in the massive sulfide exposures to the north of Central Hill were drilled with the RCB system, we decided to employ the alternative XCB/APC strategy adopted for Hole $1038 \mathrm{G}$ back in this area. Hole $1038 \mathrm{H}$ was located by camera survey near Hole 1038A to see if we could further our understanding of the sedimentation/alteration history attending the evolution of the massive sulfide deposits. We ended operations at Hole $1038 \mathrm{H}$ at a depth of 192.8 mbsf because of poor recovery.

\section{Hole 1038I}

Hole 1038I was sited at the top of Central Hill, with the intent to use our remaining operational time to document the history of sedimentation and alteration recorded here for comparison with our Reference Site 1037 . We also hoped that we could penetrate deeply enough to investigate the mechanism of uplift of Central Hill. Operations at this hole included two discrete temperature measurements and ended just after reaching basalt at $403 \mathrm{mbsf}$ when time for the leg expired.

\section{LITHOSTRATIGRAPHY AND SEDIMENTOLOGY}

Nine holes were drilled and cored at Site 1038 in the vicinity of Central Hill in the Escanaba Trough. Holes 1038A through 1038F were rotary drilled. Holes $1038 \mathrm{G}$ and $1038 \mathrm{I}$ were XCB/APC/XCB holes, and Hole $1038 \mathrm{H}$ was drilled only with the $\mathrm{XCB}$. The positions of these holes, of previously studied active hydrothermal vents, and of exposed massive sulfide are all shown in Figure 6. The stratigraphic units intersected in each hole are shown in Figure 7, listed in Table 2 , and described briefly in the following paragraphs. For a more detailed discussion of the composition of each unit, the reader is referred to the "Lithostratigraphy and Sedimentology" section, of the "Escanaba Trough Reference Site" chapter, Hole 1037B (this volume). Hole 1037B is located $5 \mathrm{~km}$ to the south of Central Hill at a water depth of $3300 \mathrm{~m}$.
An attempt was made to correlate the holes at Central Hill and Hole 1037B using magnetic susceptibility and grain-size data from the visual core descriptions. For the purposes of stratigraphic correlation, the most useful sequence at Central Hill, because of relatively mild thermal alteration and relatively complete recovery $(47.3 \%)$, is Hole 1038I, drilled on the top of Central Hill at a water depth of 3215 $\mathrm{m}$. Other sequences of particular interest for stratigraphic correlations included Holes $1038 \mathrm{G}$ (30.5\% recovery) and $1038 \mathrm{H}$ (15.6\% recovery).

\section{Lithologic Units}

Two main data sets were collected from the sedimentary strata penetrated at Central Hill that allow stratigraphic correlation between Site 1038 and the Escanaba Trough Reference Site (Hole 1037B). These data were (1) grain size, more precisely, the volume percentage of (sand + silt)/(sand + silt + clay), and (2) the magnetic susceptibility of sediments. Sulfide and igneous rocks that are present in the stratigraphic section and shown in Figure 7 are not included in this lithostratigraphic discussion; they are discussed in the "Sulfide Petrology" and "Igneous Petrology" sections of this chapter.

Using grain size and magnetic susceptibility (Fig. 8), a reasonable correlation can be made between the upper $100 \mathrm{~m}$ of core from Holes 1038A, 1038B, 1038G, 1038I, and the reference hole. Below 100 mbsf, however, stratigraphic control is limited and correlations become much more tenuous.

In general, the upper $100 \mathrm{~m}$ section of core in the reference hole and in Holes 1038A, 1038B, 1038G, and 1038I is characterized by very fine- to medium-grained sandy turbidites interbedded with silt and clay turbidites and hemipelagites. In the Central Hill area, only Hole 1038I penetrated beneath $100 \mathrm{mbsf}$ with enough recovery to allow comparison with the reference site. In Hole 1038I, sands were not recovered below 195 mbsf and are apparently rare below 100 mbsf. This is in marked contrast to cores from Hole 1037B, where very fine- to medium-grained sands were recovered in the upper 100 $\mathrm{m}$, in the 200 to $245 \mathrm{mbsf}$ interval, and between 375 and $415 \mathrm{mbsf}$. Of the eight lithologic units identified in cores from Hole 1037B, only Units II, III, and VIII can be positively identified at Hole 1038I; Units IV and V are tentatively identified. Table 3 shows the lithologic units in each hole at the Central Hill Site.

\section{Unit I (Hemipelagic Clay)}

Unit I, a hemipelagic clay unit that was only $1.68 \mathrm{~m}$ thick at Hole $1037 \mathrm{~B}$, is not present at Site 1038 , nor was it observed in many gravity cores collected previously in the region (Karlin and Zierenberg, 1994). In contrast, most of the holes at this site recovered either finegrained turbidites or massive sulfides in the upper $1.50 \mathrm{~m}$. At Hole 1038I, for example, the base of the first silty turbidite is at a depth of $48 \mathrm{~cm}$. A 3.92-m-thick fining-upward turbidite sequence at Hole $1038 \mathrm{G}$ is present from interval $169-1038 \mathrm{G}-1 \mathrm{X}-1,0 \mathrm{~cm}$, to $1 \mathrm{X}-3,104$ $\mathrm{cm}(0.00-3.92 \mathrm{mbsf})$. At Hole $1038 \mathrm{H}$, clay-altered turbiditic sediments are present directly beneath massive sulfide debris (interval $169-1038 \mathrm{H}-1 \mathrm{X}-1,40 \mathrm{~cm}$, to $1 \mathrm{X}-4,20 \mathrm{~cm}$ ).

\section{Unit II (Interbedded Fine-Grained Turbidites and Hemipelagic Muds: Holocene to Holocene?)}

The sandy intervals are most correlative with lithologic Unit II, which is characterized at Hole 1037B by graded beds of fine-grained sand to silt and clay interbedded with thin hemipelagic mudstone. In addition, the lack of lateral continuity of these near-surface sands (the sands are not correlative among the Central Hill holes) suggests that they may be derived locally from slumps or flows off the steep faultscarp walls that surround the basin. Beneath the shallow turbidites, 
ESCANABA TROUGH: CENTRAL HILL

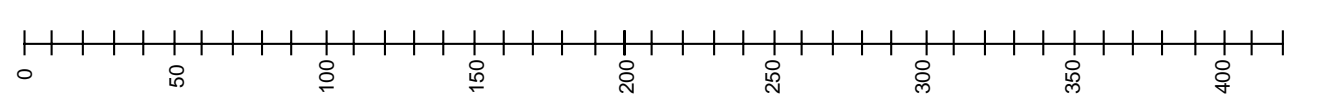
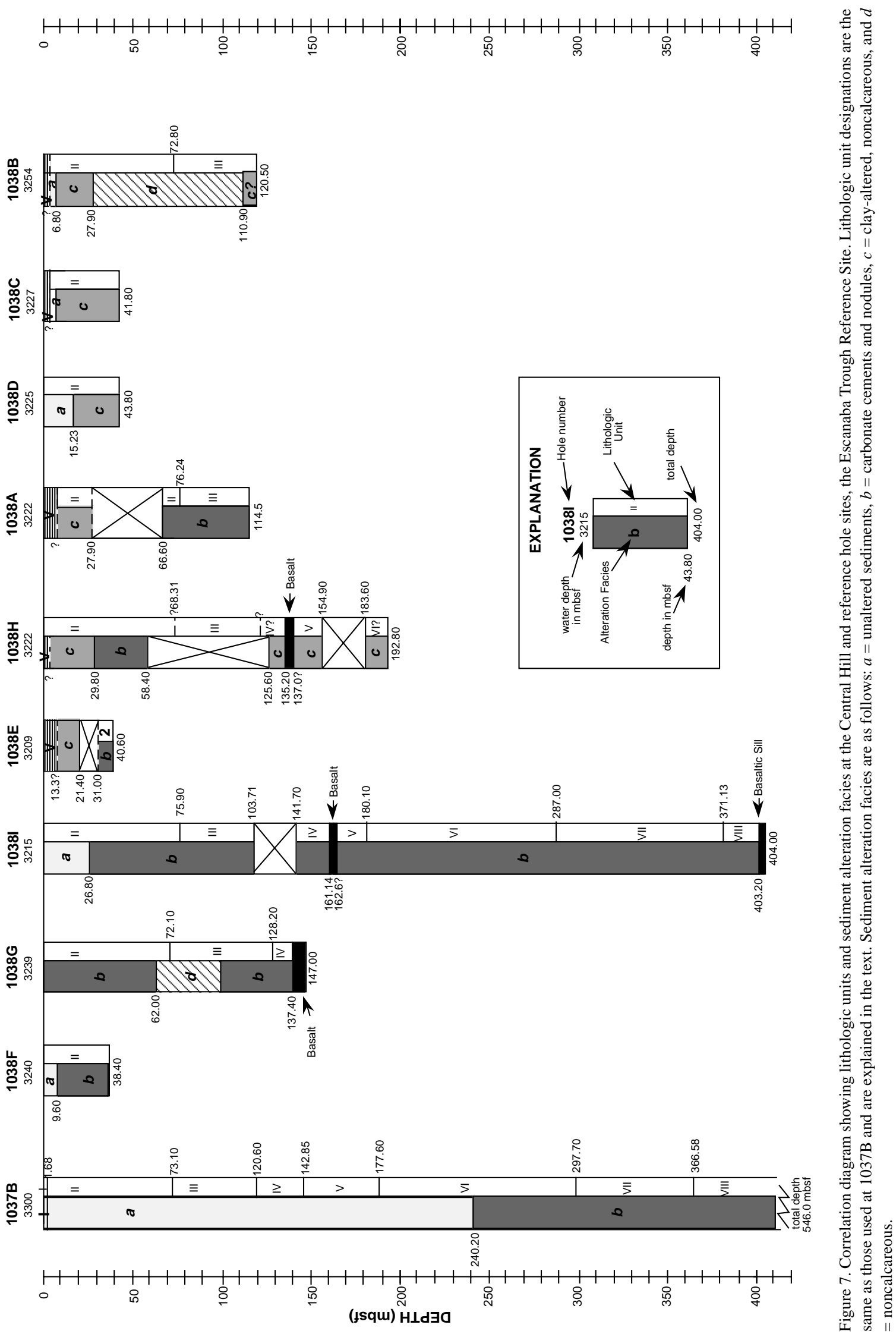
Table 2. Alteration facies, Site 1038, Escanaba Trough.

\begin{tabular}{l} 
Alteration facies by core and section \\
\hline Massive sulfide \\
$169-1038 \mathrm{~A}-1 \mathrm{R}$ \\
$169-1038 \mathrm{E}-1 \mathrm{R}$ \\
Unaltered sediments-Facies $a$ \\
$169-1038 \mathrm{~B}-1 \mathrm{R}$ \\
$169-1038 \mathrm{C}-1 \mathrm{R}-1$ \\
$169-1038 \mathrm{D}-1 \mathrm{R}$ through $2 \mathrm{R}-1$ \\
$169-1038 \mathrm{~F}-1 \mathrm{R}$ \\
$169-1038 \mathrm{I}-1 \mathrm{X}$ through $3 \mathrm{H}$ \\
Carbonate cement and nodules-Facies $b$ \\
$169-1038 \mathrm{~A}-8 \mathrm{R}$ through $12 \mathrm{R}$ \\
$169-1038 \mathrm{E}-4 \mathrm{R}$ \\
$169-1038 \mathrm{~F}-2 \mathrm{R}$ through $4 \mathrm{R}$ \\
$169-1038 \mathrm{G}-1 \mathrm{X}$ through $7 \mathrm{X}-1$ and $11 \mathrm{X}$ through $14 \mathrm{X}$ \\
$169-1038 \mathrm{H}-4 \mathrm{X}$ through $6 \mathrm{X}$ \\
$169-1038 \mathrm{I}-4 \mathrm{H}$ through $43 \mathrm{X}-2$ \\
Noncalcareous, clay altered-Facies $c$ \\
$169-1038 \mathrm{~A}-2 \mathrm{R}$ through $3 \mathrm{R}$ \\
$169-1038 \mathrm{~B}-2 \mathrm{R}$ \\
$169-1038 \mathrm{C}-1 \mathrm{R}-\mathrm{CC}$ and $3 \mathrm{R}$ through $4 \mathrm{R}$ \\
$169-1038 \mathrm{D}-2 \mathrm{R}-\mathrm{CC}$ through $4 \mathrm{R}$ \\
$169-1038 \mathrm{E}-2 \mathrm{R}$ \\
$169-1038 \mathrm{H}-1 \mathrm{X}$ through $3 \mathrm{X}, 14 \mathrm{X}$, and $16 \mathrm{X}$ through $20 \mathrm{X}$ \\
Noncalcareous- - Facies $d$ \\
$169-1038 \mathrm{~B}-3 \mathrm{R}$ through $13 \mathrm{R}$ \\
$169-1038 \mathrm{G}-7 \mathrm{X}-2$ through $10 \mathrm{X}$ \\
Basalt \\
$169-1038 \mathrm{G}-15 \mathrm{X}$ through $16 \mathrm{X}$ \\
$169-1038 \mathrm{H}-15 \mathrm{X}$ - $1038 \mathrm{I}-18 \mathrm{X}$ and $43 \mathrm{X}-3$ \\
No recovery or out-of-place \\
$169-1038 \mathrm{~A}-4 \mathrm{R}$ through $7 \mathrm{R}$ \\
$169-1038 \mathrm{C}-2 \mathrm{R}$ \\
$169-1038 \mathrm{E}-3 \mathrm{R}$ \\
$169-1038 \mathrm{G}-12 \mathrm{X}$ \\
$169-1038 \mathrm{H}-7 \mathrm{X}$ through $13 \mathrm{X}$ and $17 \mathrm{X}$ through $19 \mathrm{X}$ \\
\end{tabular}

Unit II at Central Hill is characterized by graded beds of fine sand to silt and silty clay interbedded with hemipelagic mudstone.

\section{Unit III (Sand-Rich Turbidites with Minor Hemipelagic Muds)}

The top of Unit III is a distinctive horizon. It is characterized by a change from thinly interbedded sandy and silty turbidites and hemipelagic strata to thicker, more sand-rich turbidites separated by relatively thinner mudstone intervals. The top of Unit III is identified in all holes that penetrate to a depth of at least $80 \mathrm{mbsf}$ (Fig. 7) and may be correlative to the top of an acoustically transparent layer previously identified on many seismic reflection profiles throughout this region (e.g., Davis and Becker, 1994). In Hole 1037B, Unit III consists of massive, dark gray, poorly sorted fine- to medium-grained sands between 73.10 and 120.60 mbsf. The recovery in this interval was high in Hole 1037B, but the APC cores were highly disturbed and soupy, suggesting that much of the sediment recovered in this interval was flow-in. The caliper log of Hole 1037B shows extreme washouts in Unit III (see "Downhole Measurements" section, "Escanaba Trough Reference Site" chapter, this volume). Cores from Holes 1038A, 1038B, and 1038G indicate that in the Central Hill region, Unit III consists of clay and silty clay interbedded with fine and very fine sand. Clayey intervals are present in Cores 169-1038B-10R and 13R and 169-1038G-8X and 10X. This could be a true reflection of the lithology of Unit III at both Central Hill and the reference site, or it could be a reflection of a lateral facies change (a fining and thinning of turbidite beds between the reference site and the Central Hill area) within the unit.

It is interesting to note that the top of Unit III occurs at $76.24 \mathrm{mbsf}$ in Hole 1038A, at $72.80 \mathrm{mbsf}$ in Hole $1038 \mathrm{~B}, 72.10 \mathrm{mbsf}$ at Hole 1038G, $75.90 \mathrm{mbsf}$ at Hole 1038I, and $73.10 \mathrm{mbsf}$ at Hole 1037B. All of these depths are within $4.14 \mathrm{~m}$ of one another, despite the fact that there is $\sim 40 \mathrm{~m}$ of relief between Hole 1038I (water depth $=3215 \mathrm{~m}$ ) near the crest of Central Hill and Hole 1037B on the valley floor to the south (water depth $=3300 \mathrm{~m}$ ). This implies that, as suggested by Davis and Becker (1994), the topographic expression of Central Hill is younger than the Escanaba sedimentary fill.

The base of Unit III is difficult to pick because the depth of the base of this unit in Hole 1037B was reached at Central Hill only by Holes 1038G, 1038H, and 1038I. At Holes 1038H and 1038I, there was no recovery in the interval corresponding to the predicted base of Unit III. At Hole 1038G, recovery was poor below $100 \mathrm{mbsf}$, but a fining-upward turbidite sequence with a fine- to medium-grained sand base was recovered above the basalt in interval 1038G-13X-CC, $0 \mathrm{~cm}$, to $14 \mathrm{X}-\mathrm{CC}, 30 \mathrm{~cm}(118.20-128.20 \mathrm{~cm})$. This sequence is interpreted to be the base of Unit III in Hole 1038G.

\section{Units IV and V (Fine-to Medium-Grained Sand Turbidites Interbedded with Siltstone and Claystone: Age Unknown)}

Unit IV, composed dominantly of fine-grained sediments underlying Unit III at Hole 1037B, may not be lithologically similar at Central Hill. Only at Hole 1038G, was this interval successfully recovered in the Central Hill region. In cores from that hole, strata at the depth of Unit IV in Hole 1037B include medium-grained sand (e.g., Sections 169-1038G-13X-CC through 15X-CC). In contrast, the two sands in Unit IV at Hole 1037B are very fine-grained, and the rest of the strata consists of silty clay and clay.

Medium-grained sand also is present in cores from Hole 1038I at $\sim 145$ to 180 mbsf (e.g., Core 169-1038I-16X). These sands constitute the lower portion of turbidites. Poor recovery did not allow identification of other lithologies associated with the sands, but they may be correlated with Unit V at Hole 1037B (characterized by beds of fineto medium-grained sand between 142.85 and $177.60 \mathrm{mbsf}$ in cores from Hole 1037B), and the medium-grained sand in Core 169-1038I$16 \mathrm{X}$ may be correlative with the first turbidite in Unit $\mathrm{V}$ from Hole 1037B. Other sediments in this interval at Hole 1038G include thin fining-upward sequences with very fine-grained sand bases. The corresponding depth interval for this unit in Hole $1038 \mathrm{H}$ was characterized by an interval of very poor recovery. From Hole 1038H, Cores $14 \mathrm{X}-1$ and $16 \mathrm{X}$ were the only two cores that recovered possibly in situ strata. Both cores consist of silty claystone and claystone. These cores, and the medium-grained sands recovered from Hole 1038I, suggest that Unit V consists of interbedded sandstone, siltstone, and claystone.

A thin basaltic layer was recovered in the Unit IV/Unit V interval in Holes 1038G, 1038H, and 1038I. See "Igneous Petrology" section (this chapter) for a discussion of this unit.

\section{Unit VI (Carbonate Altered Silt to Clay Turbidites and Hemipelagites: Late Pleistocene?)}

Hole $1038 \mathrm{I}$ is the only hole in the Central Hill area that reached the depth of lithologic Unit VI in Hole 1037B. In the latter hole, Unit VI is present from 177.60 to $297.70 \mathrm{mbsf}$ and is characterized by silty claystone with very rare, thin silt laminations and rare silty and clayey turbidites. At Hole 1038I, the corresponding depth interval includes a large interval in which recovery was either nonexistent or consisted mostly of pieces of drilling rubble that were washed in from uphole (interval 169-1038I-22X-CC, $0 \mathrm{~cm}$, to the base of the drilled interval for Core 169-1038I-27X, 199.40-257.10 mbsf). The few in situ strata in this interval, however, are dominated by massive, silty claystone. One turbidite with a siltstone base is present at the top, and two turbidites with siltstone to fine-grained sandstone bases are present near the bottom of the interval in Hole 1038I (interval 169-1038I-30X-1, $0 \mathrm{~cm}$, to $30 X-3,55 \mathrm{~cm}$, and $31 X-1,0-95 \mathrm{~cm}$ ). Based on the lithologic similarity and on the similarity of depth intervals, the top of Unit VI in Hole $1038 \mathrm{I}$ is placed at the top of the first siltstone-based turbidite (interval $169-1038 \mathrm{I}-21 \mathrm{X}-1,0 \mathrm{~cm} ; 180.10 \mathrm{mbsf}$ ), and the base of the unit is 

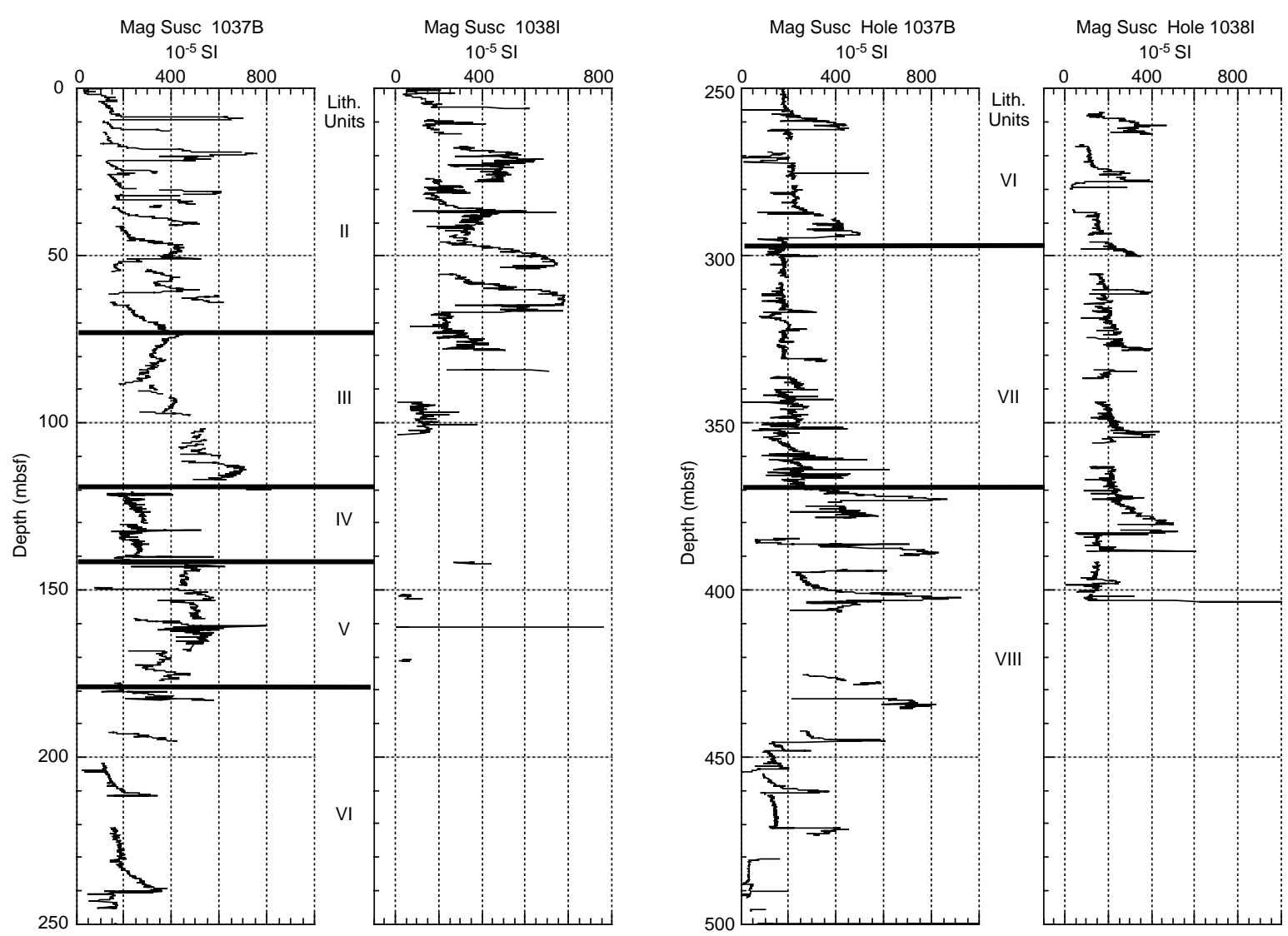

Figure 8. Magnetic susceptibility logs for Holes 1037B and 1038I showing lithologic units discussed in the text.

placed at the base of this last fine-grained sand turbidite (interval 169$1038 \mathrm{I}-31 \mathrm{X}-1,95 \mathrm{~cm} ; 287.00 \mathrm{mbsf})$. Unfortunately, the poor recovery in this depth interval makes it difficult to use the magnetic susceptibility $\operatorname{logs}$ to define the precise top and bottom of this unit. There are no magnetic susceptibility data from the top of the interval to a depth of $\sim 258 \mathrm{mbsf}$ (near the base of Unit VI, as interpreted here).

\section{Unit VII (Calcareous Silty Claystone with Minor Silty Turbidite: late Pleistocene)}

The location and thickness of Unit VII in the Central Hill area is debatable. The unit may be present at approximately the same depth interval in Hole 1038I as in Hole 1037B or, as hypothesized in the "Physical Properties" section (this chapter), it may be represented by the $15 \mathrm{~m}$ of strata above the basalt in Hole 1038I. The absence of a thick Unit VII in the stratigraphic sequence at Central Hill would imply an 88-m offset between the two holes and a corresponding thickening (more rapid sediment accumulation) of the strata above Unit VI in the Central Hill area. Stage 5, however, has been tentatively identified deeper in Hole 1037B (316 mbsf) than in Hole 1038I (280 mbsf; see "Biostratigraphy" section, this chapter).

Furthermore, seismic reflection profiles crossing both sites (Davis and Becker, 1994) give little indication of significant unconformities in shallower sediments in the region, but are of limited use in resolving the character of deeper sediments. In fact, Davis and Becker (1994) show that the acoustically transparent layer at $~ 80$ mbsf (part or all of Unit III) actually thickens with increasing water depth to the south toward Hole 1037B and away from Central Hill.

In cores from Hole 1037B, Unit VII is characterized by hemipelagic to turbiditic silty claystone between 297.70 and $366.58 \mathrm{mbsf}$ with very rare thin silty laminae and rare silty to clayey turbidites. In this hole, the unit is also characterized by very high lithium content in the pore waters (interpreted as diffusion of lithium from a lithiumenriched, perhaps stratigraphically controlled, mineral phase). Lithium content in the pore waters is much higher throughout all of the section at Hole 1038I than at Hole 1037B, so lithium is not useful as a stratigraphic marker for this unit at Central Hill. Strata in the depth interval of Unit VII at Hole 1038I are dominated by moderately indurated, calcareous silty claystones. These claystones are interbedded with rare muddy turbidites with thin siltstone bases. Only one sand lamina was observed in this part of the sequence (Sample 169-1038I$36 \mathrm{X}-1,35-40 \mathrm{~cm})$. It is a silty clayey sand at the base of an extremely disturbed, soupy zone at the top of a core and is probably not in situ. Comparison of the magnetic susceptibility logs from both holes in this depth interval (Fig. 8) show that an interval of reduced susceptibility occurs in both Holes 1037B and 1038I and that the character and amplitude of the magnetic susceptibility signature are comparable in both holes. At both locations, the magnetic susceptibility record, as well as the visual core descriptions, confirm the presence of muddy turbidites with silt bases throughout the unit.

\section{Unit VIII (Calcareous Fine-Grained Sand to Silt Turbidites: Pleistocene)}

Unit VIII was defined in Hole 1037B as graded beds of siltstone and fine-grained sandstone to claystone interbedded with thin hemipelagic mudstone. In Hole 1038I (the only hole at Central Hill to penetrate to the depth of Unit VIII), the top of Unit VIII is defined as the first occurrence of stacked siltstone turbidites with no obvious intervening hemipelagic intervals. The base of the first such turbidite sequence in this unit is present in Section 169-1038I-41X, $125 \mathrm{~cm}$ ( $383.35 \mathrm{mbsf}$ ). The turbidite is directly overlain by another silty turbidite with a base at Section 169-1038I-39X-8, $50 \mathrm{~cm}$ (377.05 mbsf). This stacked turbidite sequence is clearly visible in the cores as well 
Table 3. Central Hill lithologic units.

\begin{tabular}{|c|c|c|c|c|c|}
\hline Unit & Description & Interval & $\begin{array}{l}\text { Top } \\
\text { (mbsf) }\end{array}$ & $\begin{array}{c}\text { Bottom } \\
\text { (mbsf) }\end{array}$ & $\begin{array}{c}\text { Thickness } \\
\text { (m) }\end{array}$ \\
\hline II & Interbedded fine-grained turbidites and hemipelagic muds & $\begin{array}{l}1038 \mathrm{~A}-1 \mathrm{R}-1,0 \mathrm{~cm} \text {, to } 9 \mathrm{R}-1,0 \mathrm{~cm} \\
1038 \mathrm{~B}-1 \mathrm{R}-1,0 \mathrm{~cm} \text {, to } 11 \mathrm{R}-1,0 \mathrm{~cm} \\
1038 \mathrm{C}-1 \mathrm{R}-1,0 \mathrm{~cm} \text {, to } 4 \mathrm{R}-\mathrm{CC}, 58 \mathrm{~cm} \\
1038 \mathrm{D}-1 \mathrm{R}-1,0 \mathrm{~cm} \text {, to } 8 \mathrm{X}-1,0 \mathrm{~cm} \\
1038 \mathrm{E}-1 \mathrm{R}, 0 \mathrm{~cm} \text {, to } 4 \mathrm{R}-\mathrm{CC}, 24 \mathrm{~cm} \\
1038 \mathrm{~F}-1 \mathrm{R}-1,0 \mathrm{~cm} \text {, to } 4 \mathrm{R}-\mathrm{CC}, 16 \mathrm{~cm} \\
1038 \mathrm{G}-1 \mathrm{X}-1,0 \mathrm{~cm} \text {, to } 8 \mathrm{X}-1,0 \mathrm{~cm} \\
1038 \mathrm{H}-1 \mathrm{X}-1,0 \mathrm{~cm} \text {, to } 8 \mathrm{X}-\mathrm{CC}, 31 \mathrm{~cm} \\
1038 \mathrm{I}-1 \mathrm{X}-1,0 \mathrm{~cm} \text {, to } 9 \mathrm{X}-2,0 \mathrm{~cm}\end{array}$ & $\begin{array}{l}0.00 \\
0.00 \\
0.00 \\
0.00 \\
0.00 \\
0.00 \\
0.00 \\
0.00 \\
0.00\end{array}$ & $\begin{array}{l}76.20 \\
72.70 \\
41.80 \\
43.80 \\
40.60 \\
38.40 \\
72.70 \\
68.31 \\
75.90\end{array}$ & $\begin{array}{l}76.20 \\
72.70 \\
41.80 \\
43.80 \\
40.60 \\
38.40 \\
72.70 \\
68.31 \\
75.90\end{array}$ \\
\hline III & Sand-rich turbidites with minor hemipelagic muds & $\begin{array}{l}\text { 1038A-9R-1, } 0 \mathrm{~cm} \text {, to } 12 \mathrm{R}-1,19 \mathrm{~cm} \\
1038 \mathrm{~B}-11 \mathrm{R}-1,0 \mathrm{~cm} \text {, to } 13 \mathrm{R}-\mathrm{CC}, 19 \mathrm{~cm} \\
1038 \mathrm{G}-8 \mathrm{X}-1,0 \mathrm{~cm} \text {, to } 14 \mathrm{X}-\mathrm{CC}, 30 \mathrm{~cm} \\
1038 \mathrm{I}-9 \mathrm{X}-2,0 \mathrm{~cm} \text {, to } 12 \mathrm{X}-\mathrm{CC}, 8 \mathrm{~cm}\end{array}$ & $\begin{array}{l}76.20 \\
72.70 \\
70.10 \\
75.90\end{array}$ & $\begin{array}{l}114.50 \\
120.50 \\
128.20 \\
103.71\end{array}$ & $\begin{array}{l}38.30 \\
47.80 \\
58.10 \\
27.81\end{array}$ \\
\hline IV, $\mathrm{V}$ & Fine- to medium-grained sand turbidites interbedded with siltstone and claystone & $\begin{array}{l}1038 \mathrm{G}-14 \mathrm{X}-\mathrm{CC}, 30 \mathrm{~cm} \text {, to } 15 \mathrm{X}-\mathrm{CC}, 0 \mathrm{~cm} \\
1038 \mathrm{H}-14 \mathrm{X}-1,0 \mathrm{~cm} \text {, to } 15 \mathrm{X}-\mathrm{CC}, 0 \mathrm{~cm} \\
1038 \mathrm{H}-16 \mathrm{X}-\mathrm{CC}, 0 \mathrm{~cm} \text {, to } 17 \mathrm{X}-\mathrm{CC}, 0 \mathrm{~cm} \\
1038 \mathrm{I}-16 \mathrm{X}-\mathrm{CC}, 0 \mathrm{~cm} \text {, to } 20 \mathrm{X}-1,0 \mathrm{~cm}\end{array}$ & $\begin{array}{l}128.20 \\
125.60 \\
144.90 \\
141.70\end{array}$ & $\begin{array}{l}137.40 \\
135.20 \\
154.90 \\
180.10\end{array}$ & $\begin{array}{r}9.20 \\
9.60 \\
10.00 \\
38.40\end{array}$ \\
\hline VI & Carbonate altered silt to clay turbidites and hemipelagic muds & $1038 \mathrm{I}-21 \mathrm{X}, 0 \mathrm{~cm}$, to $31 \mathrm{X}-1,95 \mathrm{~cm}$ & 180.10 & 287.00 & 106.90 \\
\hline VII & Calcareous silty clay with minor silty turbidites & $1038 \mathrm{I}-31 \mathrm{X}-1,95 \mathrm{~cm}$, to $39 \mathrm{X}-7,10 \mathrm{~cm}$ & 287.00 & 371.13 & 84.13 \\
\hline VIII & Calcareous fine-grained sand to silt turbidites & $1038 \mathrm{I}-39 \mathrm{X}-7,10 \mathrm{~cm}$, to $43 \mathrm{X}-2,80 \mathrm{~cm}$ & 371.13 & 403.20 & 32.07 \\
\hline
\end{tabular}

as on the magnetic susceptibility log and appears to be correlative with the sandier turbidites that form the top of Unit VIII at Hole 1037B. Smear-slide analysis shows that the silt and sand-size grains in these turbidites are quartz- and feldspar-rich and also contain mica, chlorite, rock fragments, amphibole, and tourmaline. The presence of amphibole was noted as an important characteristic of the sand-sized fraction in Unit VIII in Hole 1037B.

\section{Hydrothermal Alteration}

Of special interest at Central Hill is the alteration of sediments as it pertains to diagenesis, hydrothermal circulation, basalt intrusion, and sulfide mineralization. For these purposes, each sedimentary interval has been placed into an alteration facies (Table 3; Fig. 7), defined solely on the basis of visual core description and smear-slide analyses (these identifications should thus be viewed with caution until substantiated with further chemical and mineralogical studies).

Facies $a$ is defined as relatively unaltered primary sediment. Details on these sediments are provided in the above section. Facies $b$ contains authigenic carbonate in the form of cement or carbonate nodules. This facies is identified on the basis of the visual identification of carbonate nodules, microscopic identification of carbonate cements, and reaction of bulk sediments with $10 \%$ hydrochloric acid. Although the unaltered sediment contains minor amounts of carbonate, the often copious addition of authigenic carbonate to the sediments makes this test a useful, though not infallible, indicator of thermally accelerated rates of diagenesis.

Facies $c$ is defined as clay- and chlorite-altered, noncalcareous sediments. Similar sediments have been studied by Zierenberg and Shanks (1994). In Core 169-1038A-3R, there is a highly altered, bluish gray $(5 \mathrm{~B} 6 / 1)$, very soft but compact brecciated claystone that is altered to chlorite or Mg-smectite. In Section 169-1038B-2R-2, there are clasts of chlorite, barite, and anhydrite intermingled with clasts of massive sulfide. At Hole 1038D, gray (N5) calcareous, but somewhat altered, silty clay, with almost no magnetic susceptibility (Cores 1691038D-1R and 2R), overlies gray (N5) noncalcareous, more highly altered, carbon black-impregnated, silty claystone (Cores 1691038D-3R and 4R). In Core 169-1038E-2R, there is a clast of gray (N6), highly chlorite(?)-altered claystone veined by an intergrowth of barite and pyrite and covered by a bituminous residue. In Cores 169$1038 \mathrm{C}-1 \mathrm{R}$ through $4 \mathrm{R}$, there are several clasts of altered, noncalcareous, silver to gray (N4 to N5) claystone. A well-developed example of the clay-altered facies is present in interval $169-1038 \mathrm{H}-1 \mathrm{X}-1,0 \mathrm{~cm}$ through $1 \mathrm{X}-4,20 \mathrm{~cm}$, where a fining-upward turbidite sequence contains a basal, pale green (5G7/1), bleached chloritized (Fe-chlorite?) very fine sandstone. The sandstone fines upward to a light gray (N7) siltstone that is, in turn, overlain by altered gray (N5) silty claystone. Massive pyrrhotite clasts (possibly fall-in from the top of the hole) are interbedded at a few levels. The sediments are broken in a few places by fractures that contain a greenish alteration halo of chlorite. A deeper zone in Hole 1038H (Cores 169-1038H-15X, 16X, and 20X) containing bleached or chloritized gray (N5) claystone also is placed in Facies $c$. This alteration may have been caused by hydrothermal circulation associated with basalt recovered from this interval, which could be a sill (Cores 169-1038H-15X and 16X).

Alteration Facies $c$ is generally limited to shallow sediments underlying massive sulfide deposits in a few holes that are very near to active hydrothermal vents. In Holes 1038A, 1038E, and 1038H, the hydrothermal alteration Facies $c$ is underlain by the carbonate Facies $b$, a succession that is believed to represent more altered sediments overlying less altered ones. This sequence could result from the lateral flow of hydrothermal fluids above a shallow seawater recharge zone.

Facies $d$ is used to describe sediments from which all carbonate minerals have been dissolved, presumably as a result of replacement or of dissolution by advecting hydrothermal fluids. These sediments are not placed in Facies $c$, because they do not appear to have hydrothermal clay or chlorite alteration: they are not silvery or bluish gray in color; they do not have soapy (talc-like) texture; they are not "punky." Cores 169-1038B-3R to 13R contain dark grayish brown (10YR4/2), dark gray (5Y4/1), "khaki," or (5Y5/1), olive-gray (5Y5/ $2)$, greenish gray $(5 \mathrm{GY} 5 / 1)$, or dark greenish gray (5GY4/1) sandstones to claystones that are noncalcareous, contain some oil or tar, and comprise fining-upward sequences. They may contain some smectite. Other alteration features found in this interval include a quartz vein at Section 169-1038B-6R-1, $52 \mathrm{~cm}$; possible anhydrite in a few centimeter-scale patches in Section 169-1038B-13R-1; and a fracture filled with quartz and anhydrite or barite in Section 1691038B-13R-CC. The greenish color of a sandstone present in Section 169-1038B-13R-1 seems to be imparted by a green clino-amphibole (actinolite?) seen in smear slides.

Alteration Facies $c$ is surprisingly poorly developed in sediments recovered from Site 1038. Likewise, the almost complete absence of anhydrite in sediments from Site 1038 is surprising when contrasted 


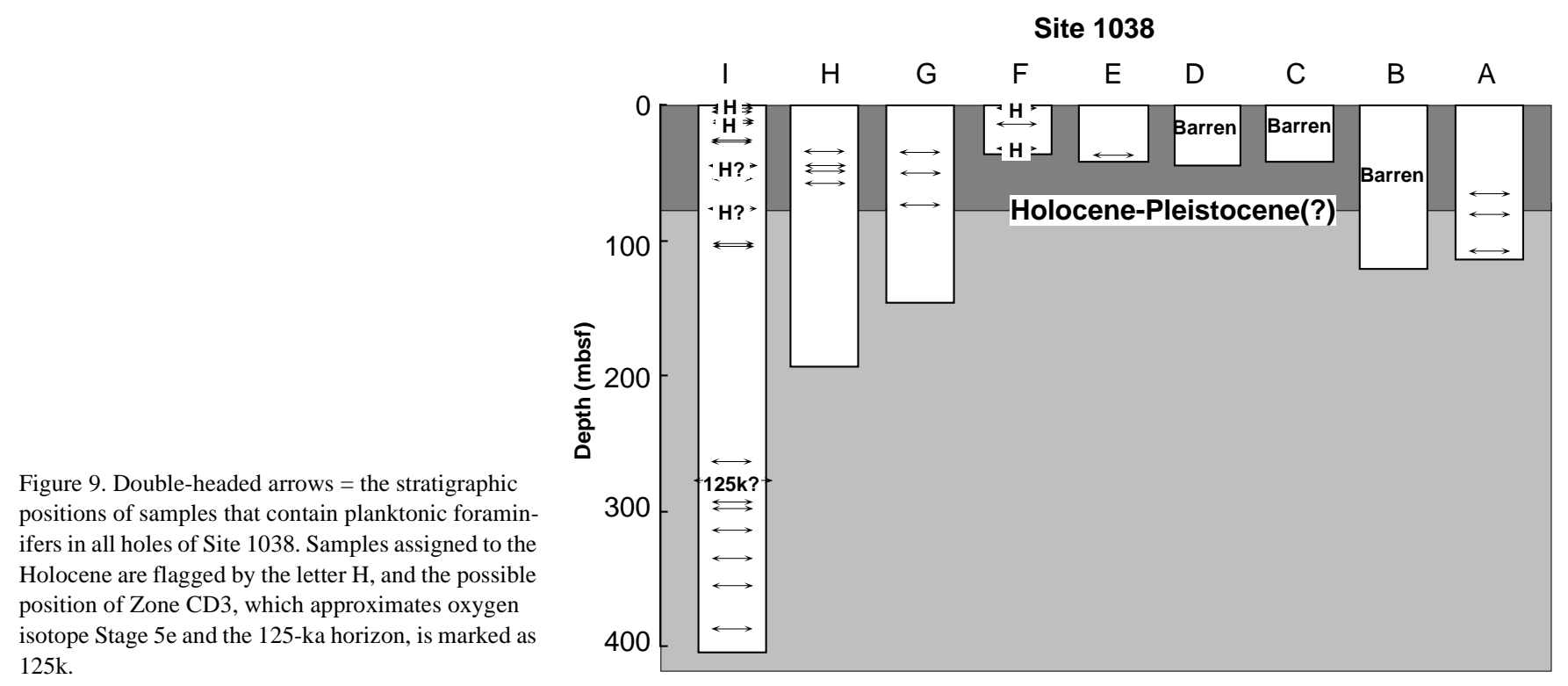

with its abundance at Bent Hill, Site 1035 (see "Sulfide Mineralization: Hydrothermal Alteration" section, "Bent Hill" chapter, this volume) and Site 1036. This observation implies that shallow hydrothermal recharge into sediments in the vicinity of vent sites at Site 1038 was probably limited. Bischoff and Dickson (1975) have discussed the large amount of acid generated during magnesium metasomatism, and it is likely that this process accounts for the lack of carbonate in Facies $c$.

\section{BIOSTRATIGRAPHY}

Most samples from Site 1038 contain few foraminifers or are barren because of dilution by terrigenous mineral debris and thermal and hydrothermal alteration (Table 4 on the back-pocket foldout, this volume). Cores from Hole 1038B on the northwest flank of Central Hill and Holes 1038C and 1038D on the north flank are totally barren of both planktonic and benthic foraminifers, and exhibit evidence of the effects of high temperatures. The cores from holes to the east and south of Central Hill contain only sporadic occurrences of planktonic foraminifers, and these are typically rare or few in abundance and poor in preservation. Despite these limitations, the cores offer several interesting pieces of information.

First, Hole 1038F provides confirmation that Holocene sedimentation is exceptionally fast, as it is at the Escanaba Trough Reference Site (1037). Samples assignable to the Holocene, found at 10 and 29 mbsf (169-1038F-1R-CC, 10-12 cm, and 4R-CC, 52-54 cm), suggest a sedimentation rate in excess of $290 \mathrm{~cm} / \mathrm{k} . \mathrm{y}$. Hole $1038 \mathrm{I}$ has samples tentatively assigned to the Holocene at depths of 46.27 and $78.20 \mathrm{mbsf}$ (169-1038I-5H-CC, 22-24 cm, and 9X-CC, 8-10 cm). Further biostratigraphic interpretations are very tentative (Fig. 9). A turbidite sand at 279.77 mbsf (Sample 169-1038I-30X-CC, 32-34 $\mathrm{cm}$ ) may belong to planktonic foraminifer zone CD3, which is probably equivalent to oxygen isotope Stage 5e. Shore-based work may improve the biostratigraphic resolution.

A second point of interest lies in the preservation states of the foraminifers at Holes 1038A, 1038F, 1038G, 1038H, and 1038I (Table 4 on the back-pocket foldout, this volume). The planktonic and benthic foraminifers are altered in various ways, including discoloration from white to golden brown hues in intervals where pine pollen grains are also discolored, increasing shell distortion because of re- crystallization of calcite rhombs in the test walls, flattening of tests, and formation of pyrite casts, including two exceptional cases where perfect casts of the benthic foraminifer, Globobulimina pacifica were formed (Samples 169-1038G-7X-CC, 36-38 cm, and 169-1038G$10 \mathrm{X}-\mathrm{CC}, 35-37 \mathrm{~cm})$. The alteration is clearly associated with thermal and hydrothermal effects.

\section{SULFIDE PETROLOGY}

Nine holes were drilled in the vicinity of the uplifted Central Hill in the Northern Escanaba Trough Study Area (Holes 1038A through 1038I). Most drilling sites were chosen in areas with known sulfide mineralization on the seafloor. Originally, these were discovered by deep-tow photography and sampled using the SeaCliff and Alvin submersibles (Zierenberg et al., 1994). The Leg 169 drill holes are clustered in three areas (Figs. 1, 6). Holes 1038A, 1038B, 1038E, and $1038 \mathrm{H}$ are located on the northwest flank of Central Hill, where $108^{\circ}$ and $217^{\circ} \mathrm{C}$ vent fluids were sampled (Campbell et al., 1994). Holes $1038 \mathrm{C}$ and $1038 \mathrm{D}$ are on the north flank of the hill. Holes $1038 \mathrm{~F}$ and $1038 \mathrm{G}$ are on the southeast flank of the hill, where diffuse venting supports biological communities. Core recovery indicates that the sulfides are only present as thin, <20-m-thick mounds and veneers overlying the sedimentary cover, and unfortunately, present drilling technology is not able to efficiently recover this type of shallow and surficial mineralization.

Sulfides were recovered in Hole 1038A, 1038B, 1038C, 1038E, $1038 \mathrm{G}$, and $1038 \mathrm{H}$ and comprise mainly fragments from drilling; no oriented pieces were obtained (Table 5). Recovery of in situ massive sulfide was limited to intervals $169-1038 \mathrm{~A}-1 \mathrm{R}-1,0-42 \mathrm{~cm}(0-0.42$ mbsf), and 169-1038E-1R-1, $0 \mathrm{~cm}$, to 3R-1, $5 \mathrm{~cm}$ (0-21.45 mbsf). In these intervals, no intercalated sediments or sedimentary rocks were recovered, possibly because of a biased sample recovery. In the other holes the massive sulfide is simply rubble that fell in from the top of the holes and is found at the top of cores from different depths downhole. Despite this lack of stratigraphic continuity, the fragments are samples of massive sulfide that is present at or near the seafloor, and hence are generally representative of the mineralogy and textures of the Central Hill sulfide mineralization. No thin sections were made, and the following presentation of sulfides is only based on visual descriptions and a few X-ray diffraction (XRD) identifications. 
Table 5. Sulfide occurrences at Central Hill, Escanaba Trough.

\begin{tabular}{|c|c|c|c|c|}
\hline $\begin{array}{l}\text { Core, section, } \\
\text { interval }(\mathrm{cm})\end{array}$ & $\begin{array}{l}\text { Depth } \\
\text { (mbsf) }\end{array}$ & Type & Mineralogy & Description \\
\hline \multicolumn{5}{|c|}{ In situ massive sulfides: } \\
\hline $\begin{array}{l}169-1038 \mathrm{~A}- \\
1 \mathrm{R}-1,0-41.5 \\
1 \mathrm{R}-1,0-15 \\
\text { 2R-1, } 0-18 \\
\text { 3R-1, } 0-5\end{array}$ & $\begin{array}{l}0.00-0.42 \\
0.00-0.15 \\
13.30-13.48 \\
21.40-21.45\end{array}$ & $\begin{array}{l}\text { Massive sulfide } \\
\text { Massive sulfide } \\
\text { Massive sulfide } \\
\text { Massive sulfide }\end{array}$ & $\begin{array}{l}\text { Py/anh-qz } \\
\text { Po-py-sl-(anh) } \\
\text { Po-py-sl-(ba) } \\
\text { Py-po-sl }\end{array}$ & $\begin{array}{l}\text { Pyrite in vuggy breccia and chimney fragments } \\
\text { Pyrrhotite, mainly compact, partly replaced by pyrite } \\
\text { Pyrrhotite, mainly compact, } 1 \text { piece rich in barite } \\
\text { Pyrite, replacing pyrrhotite }\end{array}$ \\
\hline \multicolumn{5}{|c|}{ Massive sulfide fragments fallen in from top of holes: } \\
\hline $\begin{array}{l}\text { 169-1038A- } \\
\text { 2R-CC, } 11-12.5 \\
\text { 3R, 15-32 } \\
\text { 4R-1, 0-5 } \\
\text { 5R-1,0-5 }\end{array}$ & $\begin{array}{l}8.59-8.63 \\
18.35-18.52 \\
27.90-27.95 \\
37.60-37.65\end{array}$ & $\begin{array}{l}\text { Massive sulfide } \\
\text { Massive sulfide } \\
\text { Massive sulfide } \\
\text { Massive sulfide }\end{array}$ & $\begin{array}{l}? \\
\text { Py-po/qz-anh } \\
\text { Po-py/anh } \\
\text { Py }\end{array}$ & $\begin{array}{l}\text { Pyrrhotite-pyrite massive breccia and chimney rubble, fallen in? } \\
\text { Pyrrhotite, hexagonal, vuggy, later fractures with pyrite } \\
\text { Pyrite, massive }\end{array}$ \\
\hline $\begin{array}{l}169-1038 \mathrm{~B}- \\
1 \mathrm{R}-1,0-140 \\
2 \mathrm{R}-2,50-55 \\
2 \mathrm{R}-2,110-120 \\
2 \mathrm{R}-3,52-53 \\
2 \mathrm{R}-\mathrm{CC}, 5-6\end{array}$ & $\begin{array}{c}0.00-1.40 \\
8.80-8.85 \\
9.40-9.50 \\
10.32-10.33 \\
10.45-10.46\end{array}$ & $\begin{array}{l}\text { Disseminated sulfide? } \\
\text { Massive sulfide } \\
\text { Massive sulfide } \\
\text { Massive sulfide } \\
\text { Massive sulfide }\end{array}$ & $\begin{array}{l}\text { ? } \\
\text { Po/anh-tc? } \\
\text { Po-ba, anh/qz-tc? } \\
\text { Po-sl?/tc?-ba } \\
\text { Po-sl?/tc?-ba-anh }\end{array}$ & $\begin{array}{l}\text { Sulfide, sand-sized grains in soupy section } \\
\text { Pyrrhotite, partly vuggy, hexagonal } \\
\text { Pyrrhotite, massive, partly vuggy, later veins of quartz, barite, and anhydrite } \\
\text { Pyrrhotite, vuggy, hexagonal, open network of clear barite crystals } \\
\text { Pyrrhotite, vuggy, interstitial talc and vugs with barite crystals and late veinlets of } \\
\text { anhydrite }\end{array}$ \\
\hline $\begin{array}{l}169-1038 \mathrm{C}- \\
1 \mathrm{R}-1,0-78 \\
1 \mathrm{R}-1,78-112 \\
1 \mathrm{R}-\mathrm{CC}, 0-15 \\
\text { 2R-CC, } 0-10\end{array}$ & $\begin{array}{c}0.00-0.78 \\
0.78-1.12 \\
1.12-1.27 \\
14.60-14.70\end{array}$ & $\begin{array}{l}\text { Sand with sulfides } \\
\text { Sand with sulfides } \\
\text { Clayey silt w/sulfide clasts } \\
\text { Massive sulfide }\end{array}$ & $\begin{array}{l}\text { Py-sl-(po)-(cp) } \\
\text { Py-sl-po-(cp) } \\
\text { Po-sl-(ba) } \\
\text { Po-py-sl-ba-(icb) }\end{array}$ & $\begin{array}{l}\text { Sulfides that are sand sized, } 10 \%-20 \% \\
\text { Sulfides that are mainly sand sized, } 40 \%-50 \% \\
\text { Pyrrhotite and sphalerite, compact clasts, and crust with barite } \\
\text { Pyrrhotite and sphalerite with abundant barite, compact, partly later veinlets of } \\
\text { pyrrhotite } \\
\text { Pyrrhotite, fine grained and massive }\end{array}$ \\
\hline $\begin{array}{l}169-1038 \mathrm{H}- \\
1 \mathrm{X}-1,0-137 \\
1 \mathrm{X}-3,79-81 \\
2 \mathrm{X}-1,0-140 \\
2 \mathrm{X}-2,0-140 \\
6 \mathrm{X}-1,0-13 \\
7 \mathrm{X}-\mathrm{CC}, 0-5 \\
8 \mathrm{X}-\mathrm{CC}, 0-22 \\
10 \mathrm{X}-\mathrm{CC}, 0-4 \\
11 \mathrm{X}-\mathrm{CC}, 0-3 \\
14 \mathrm{X}-1,0-30 \\
14 \mathrm{X}-\mathrm{CC}, 0-28 \\
16 \mathrm{X}-\mathrm{CC}, 0-18 \\
18 \mathrm{X}-1,0-6\end{array}$ & $\begin{array}{c}0.00-1.37 \\
3.79-3.81 \\
11.90-13.40 \\
13.40-14.80 \\
48.70-48.83 \\
66.04-66.09 \\
68.00-68.22 \\
87.10-87.32 \\
96.70-96.73 \\
125.50-125.80 \\
125.80-126.08 \\
144.80-144.98 \\
164.00-164.06\end{array}$ & $\begin{array}{l}\text { Clay and silt w/sulfide clasts } \\
\text { Massive sulfide clasts } \\
\text { Massive sulfide fragment } \\
\text { Massive sulfide fragment } \\
\text { Massive sulfide fragment } \\
\text { Massive sulfide fragment } \\
\text { Massive sulfide fragment } \\
\text { Massive sulfide fragments } \\
\text { Massive sulfide fragments } \\
\text { Massive sulfide fragments } \\
\text { Massive sulfide fragments } \\
\text { Massive sulfide fragments } \\
\text { Massive sulfide fragments }\end{array}$ & $\begin{array}{l}\text { Po } \\
\text { Po } \\
\text { Po } \\
\text { ? } \\
\text { Po-(py) } \\
\text { Py } \\
\text { Po-sl } \\
\text { Po-(ba) } \\
\text { Po-py-(ba)-(icb) } \\
\text { Po } \\
\text { Po } \\
\text { Po } \\
\text { Po }\end{array}$ & $\begin{array}{l}\text { Pyrrhotite, fibrous, chimney clasts } \\
\text { Pyrrhotite clasts, rounded, in sand } \\
\text { Pyrrhotite, } 1 \text { clast } \\
\text { Sulfides, scattered, <2\% } \\
\text { Pyrrhotite, compact fine to coarse network of hexagonal plates } \\
\text { Pyrite, fine-grained crystals } \\
\text { Pyrrhotite-sphalerite in fine-grained intergrowth } \\
\text { Pyrrhotite, fine, partly vuggy, gangue of rare barite } \\
\text { Pyrrhotite, partly vuggy, with veins of pyrite and rare barite and Cu-Fe sulfides? } \\
\text { Pyrrhotite, } 2 \% \text { of material } \\
\text { Pyrrhotite, } 1 \% \text { of material } \\
\text { Pyrrhotite, massive, fine grained } \\
\text { Pyrrhotite, massive, fine grained }\end{array}$ \\
\hline \multicolumn{5}{|c|}{ Disseminated sulfides: } \\
\hline $\begin{array}{l}\text { 169-1038B- } \\
2 \mathrm{R}-2,55-61^{*} \\
4 \mathrm{R}-\mathrm{CC}, 35-40^{*}\end{array}$ & $\begin{array}{c}8.85-8.91 \\
24.55-24.60\end{array}$ & $\begin{array}{l}\text { Disseminated sulfide } \\
\text { Disseminated sulfides }\end{array}$ & $\begin{array}{l}\text { Py-(po)/chl-anh-(ba) } \\
?\end{array}$ & Pyrite, disseminated in chlorite with veins of anhydrite and barite? \\
\hline $\begin{array}{l}169-1038 \mathrm{C}- \\
4 \mathrm{R}-1,0-52 \\
4 \mathrm{R}-\mathrm{CC}, 0-5\end{array}$ & $\begin{array}{l}32.20-32.72 \\
32.81-32.86\end{array}$ & $\begin{array}{l}\text { Disseminated sulfides } \\
\text { Disseminated sulfides }\end{array}$ & $\begin{array}{l}\text { Po-(py)-(icb) } \\
\text { Po-(py)-(icb) }\end{array}$ & $\begin{array}{l}\text { Sulfides, } 2 \%-5 \% \text { disseminated in altered mud } \\
\text { Sulfides, } 2 \%-5 \% \text { disseminated in altered mud }\end{array}$ \\
\hline $\begin{array}{l}169-1038 \mathrm{E}- \\
\quad 4 \mathrm{R}-1,0-8\end{array}$ & $31.00-31.08$ & Sandstone with sulfides & Py-mc-(po) & $\begin{array}{l}\text { Pyrite and possibly marcasite or pyrrhotite impregnated, highly silicified sandstone, } \\
50 \% \text { sulfides }\end{array}$ \\
\hline $\begin{array}{l}169-1038 \mathrm{G}- \\
6 \mathrm{X}-2,58-151 \\
7 \mathrm{X}-2,0-140\end{array}$ & $\begin{array}{l}53.08-54.51 \\
62.00-63.40\end{array}$ & $\begin{array}{l}\text { Disseminated sulfides } \\
\text { Disseminated sulfides }\end{array}$ & $\begin{array}{l}\text { Po } \\
\text { Po }\end{array}$ & $\begin{array}{l}\text { Pyrrhotite, hexagonal in weak disseminations }(2 \%-10 \%) \\
\text { Pyrrhotite, disseminated, } ~ 5 \%\end{array}$ \\
\hline $\begin{array}{l}169-1038 \mathrm{H}- \\
15 \mathrm{X}-\mathrm{CC}, 0-9\end{array}$ & $135.20-135.29$ & Sulfide-veined basalt & Py-(po) & Pyrite (replacing pyrrhotite) in veinlets with chlorite and calcite \\
\hline
\end{tabular}

Notes: $*=$ fall-in occurrences of sulfides from top of holes. Py $=$ pyrite, anh $=$ anhydrite, $q z=$ quartz, po $=$ pyrrhotite, sl $=$ sphalerite, ba $=$ barite, tc $=$ talc, icb $=$ isocubanite, chl $=$ chlorite, and $\mathrm{mc}=$ marcasite

\section{Massive Sulfides}

\section{Occurrences}

Probable in situ massive sulfide was recovered at the $217^{\circ} \mathrm{C}$ vent site in Hole 1038A (interval 169-1038A-1R-1, 0-42 cm; 0-0.42 mbsf) and in Hole 1038E (interval 169-1038E-1R-1, $0 \mathrm{~cm}$, to 3R-1, $10 \mathrm{~cm}$; 0-21.5 mbsf). Fragments of massive sulfide (fallen in from the top of the holes) were recovered in Hole 1038A (Sections 1691038A-2R-CC, 3R-1, 4R-1, and 5R-1), Hole 1038B (Sections 1691038B-2R-2, 2R-3, and 2R-CC), Hole 1038C (Sections 169-1038C1R-CC, 2R-CC, and 3R-1), and Hole 1038H (Sections 169-1038H $1 \mathrm{X}-1,1 \mathrm{X}-3,2 \mathrm{X}-1,2 \mathrm{X}-2,6 \mathrm{X}-1,7 \mathrm{X}-\mathrm{CC}, 8 \mathrm{X}-\mathrm{CC}, 10 \mathrm{X}-\mathrm{CC}, 11 \mathrm{X}-\mathrm{CC}$, $16 \mathrm{X}-\mathrm{CC}$, and 18X-1). Massive sulfides were recovered from the northwestern and northern flank of Central Hill, but not from the southeast flank (Fig. 6).

\section{Mineralogy and Textures}

The massive sulfides are mainly composed of pyrrhotite and pyrite (Table 5). Pyrrhotite is more abundant than pyrite. The more indurated massive sulfide is composed of fine-grained to mediumgrained hexagonal pyrrhotite, typically forming an interlocking open network. Variations in the pyrrhotite grain size in a single 1- to $2-\mathrm{cm}$ fragment are common. Pyrrhotite is, in part, locally replaced by pyrite, which also occurs as crosscutting veins and veinlets. Deep red to black sphalerite is abundant in several of the fall-in fragments and occurs mainly intergrown with pyrrhotite, or as interstitial botryoidal masses within an open pyrrhotite network. Marcasite is present in some fragments, associated with pyrite. Minor $\mathrm{Cu}-\mathrm{Fe}$ sulfide, probably isocubanite, which can be recognized by its color and rapid oxidation, occurs in some clasts. Yellow and red crusts are present in 
Table 6. X-ray diffraction identifications, Hole 1038B.

\begin{tabular}{|c|c|c|}
\hline $\begin{array}{l}\text { Core, section, } \\
\text { interval }(\mathrm{cm})\end{array}$ & Description & XRD mineralogy \\
\hline $\begin{array}{l}169-1038 \mathrm{~B}- \\
2 \mathrm{R}-2,56-56\end{array}$ & $\begin{array}{l}\text { Anhydrite/barite from sulfide } \\
\text { fragment }\end{array}$ & Anhydrite $>>$ gypsum \\
\hline 2R-2, 59-59 & $\begin{array}{l}\text { Greenish clay from fragment in } \\
\text { silty clay }\end{array}$ & $\begin{array}{l}\text { Chlorite }>\text { muscovite }> \\
\text { chalcopyrite }\end{array}$ \\
\hline $2 \mathrm{R}-2,120-120$ & $\begin{array}{l}\text { Orange-red minerals with } \\
\text { sulfate }\end{array}$ & Barite $\gg>$ anhydrite \\
\hline
\end{tabular}

fragments at both the $217^{\circ} \mathrm{C}$ vent site (interval $169-1038 \mathrm{~B}-2 \mathrm{R}-2$, $110-120 \mathrm{~cm}$ ) and in Hole 1038C (interval 169-1038C-1R-CC, 0-15 $\mathrm{cm})$. XRD detected only barite and lesser anhydrite and no arsenic minerals (Table 6). Several samples have very similar orange and dark red iron oxide coatings (lepidocrocite), often developed preferentially on one side, confirming these samples were weathered at the surface of the mounds before recovery. Native sulfur was identified visually as a weathering product of pyrrhotite.

Major gangue minerals are anhydrite and a greenish gray, soft, very fine-grained mineral, probably talc or Mg-smectite. Anhydrite was only observed in the areas of active venting. Barite is locally abundant and is typically associated with pyrrhotite and sphalerite. Quartz/amorphous silica occurs as a major gangue mineral in a few fragments.

The in situ massive sulfides from Holes 1038A and 1038E, and some of the fall-in clasts in the upper cores of other holes, appear to comprise disaggregated mound material and chimney fragments,

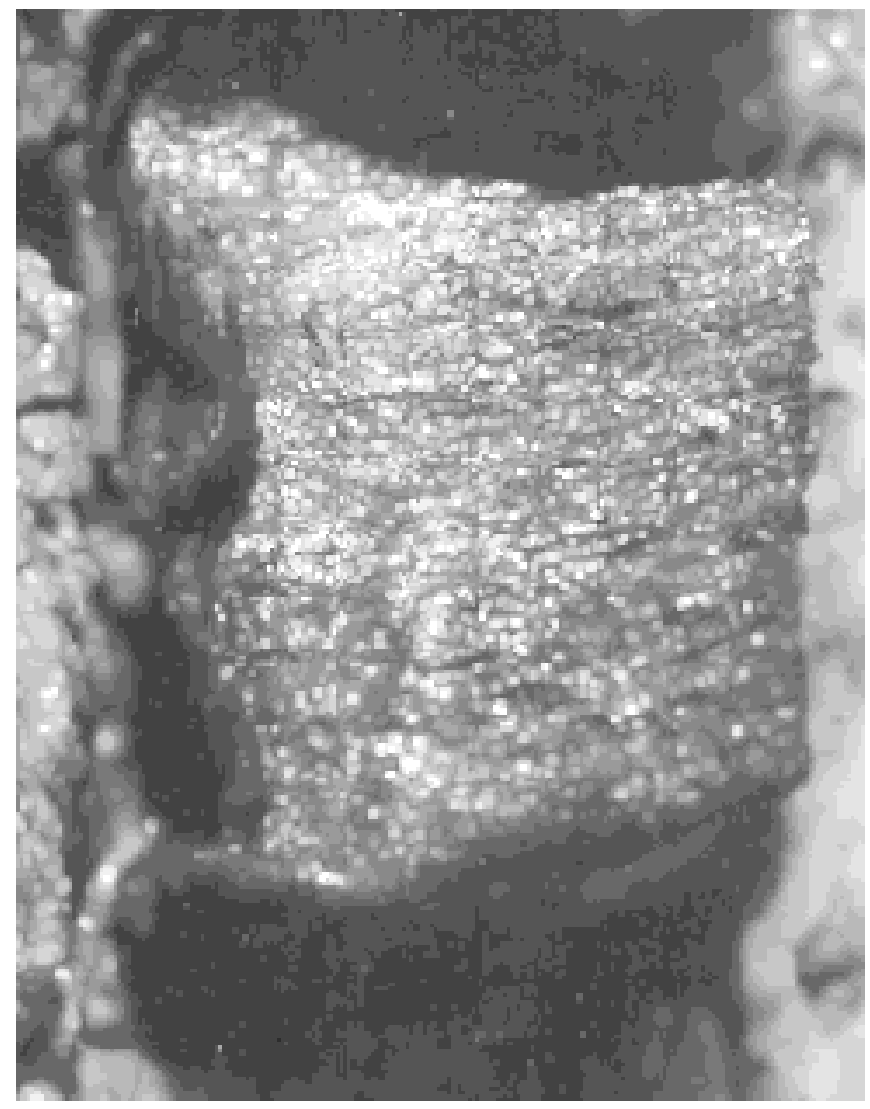

Figure 10. Massive, columnar aggregates of fibrous pyrrhotite, growing perpendicular to the conduit or fluid channelway. Fragment in silty clay, $\sim 3 \mathrm{~cm}$ $\times 2 \mathrm{~cm}$ in size (interval $169-1038 \mathrm{H}-1 \mathrm{X}-1,10 \mathrm{~cm} ; 0.10 \mathrm{mbsf}$ ).

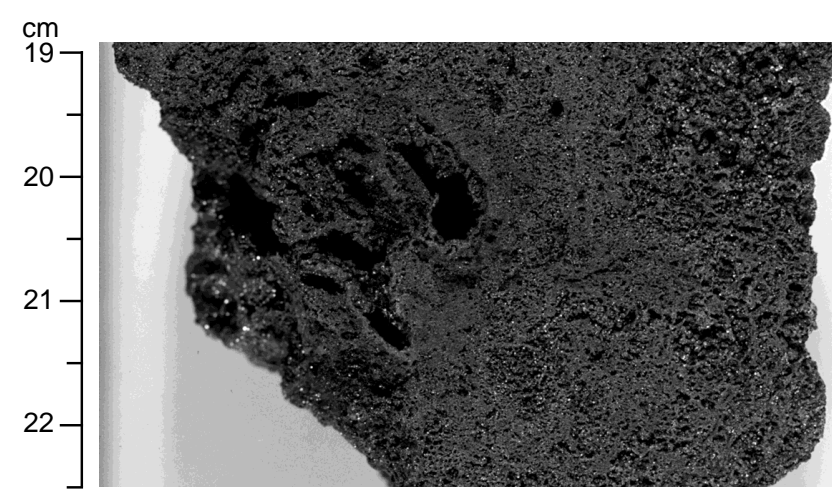

Figure 11. Vuggy pyrite (interval 169-1038A-1R-1, 19-22.5 cm).

commonly with fossil channelways or conduits preserved. Some chimney-type clasts consist of coarse-grained vuggy pyrite with 2- to 5 -mm conduits lined with finer grained euhedral pyrite (Fig. 10). The vuggy pyrite is not typical for samples from the sulfide deposits at Central Hill that were recovered during previous sampling by submersibles or dredging (Koski et al., 1994). In other pieces, the fluid channelways are defined by variations in grain size of pyrrhotite. In Hole 1038H (Section 169-1038H-1X-1, 10 and $115 \mathrm{~cm}$ ), two clasts, 2 to $3 \mathrm{~cm}$ wide, consist of fibrous columnar aggregates of pyrrhotite that presumably have grown perpendicular to a hydrothermal conduit (Fig. 11).

\section{Disseminated Sulfides in Sediments}

Disseminated sulfides were recovered in Hole 1038B (intervals 169-1038B-2R-2, 55-61 cm, and 4R-CC, $35-40 \mathrm{~cm}$ ), in Hole $1038 \mathrm{C}$ (intervals 169-1038C-4R-1, 0-52 cm, and 4R-CC, 0-5 cm), in Hole 1038E (interval 169-1038E-4R-1, 0-8 cm) and in Hole 1038G (intervals $169-1038 \mathrm{G}-6 \mathrm{X}-2,58-151 \mathrm{~cm}$, and $7 \mathrm{X}-2,0-140 \mathrm{~cm}$ ). The disseminated sulfides in Hole 1038B are drill cuttings that have fallen down the hole, whereas the other occurrences seem to be in situ. The in situ occurrences are mainly weak impregnations (2\%-10\%) of pyrrhotite with minor pyrite in sand, silt, and clay. Minor amounts of $\mathrm{Cu}$ $\mathrm{Fe}$ sulfide are present in the core from Hole 1038C. The disseminated sulfides in Hole $1038 \mathrm{C}$ are associated with chlorite-altered silty clay, whereas no alteration was observed in the Hole $1038 \mathrm{G}$ occurrences.

A fragment that may have been recovered in situ in Hole 1038E (interval 169-1038E-4R-1, 0-8 cm) consists of a highly silicified sandstone impregnated by pyrite, marcasite, and possibly pyrrhotite. Pyrite fills vugs and forms a thin crust on the outer edge of the fragment, as well as impregnating the sandstone. This piece immediately underlies the massive sulfide and is probably part of a thin, poorly developed feeder zone below the deposit.

The fragments in Hole 1038B consist of very fine-grained chlorite with euhedral pyrite. This assemblage was crosscut by veinlets of anhydrite and minor barite. The presence of chlorite, anhydrite, and barite was confirmed by XRD analysis (Table 6). This assemblage seems to have completely replaced the protolith and probably represents the most intense alteration recovered from the presumed feeder zone.

\section{Summary and Discussion}

The massive sulfides recovered from Site 1038 consist predominantly of massive pyrrhotite or vuggy pyrite. Sphalerite is locally abundant and is associated with pyrrhotite. The poor recovery of sulfides during this leg did not confirm the presence of high $\mathrm{Pb}$ and $\mathrm{As}$ content in the deposits at Central Hill, which have been recovered previously (Koski et al., 1988, 1994; Zierenberg et al., 1993), and 
which suggested that the fluids precipitating the Central Hill sulfides have reacted extensively with sediments and have leached metals during this interaction. The paucity of massive sulfide recovered from this site suggests that the mineralization forms only a thin veneer (5-15 m) over the sedimentary sequence of Central Hill. No major intersections of massive sulfide were recovered. The recovery of sediments at shallow depth beneath the surficial sulfides (see "Lithostratigraphy and Sedimentology" section, this chapter) and the absence of a well- developed feeder system rules out the possibility of a thick $(>25 \mathrm{~m}$ ) sulfide lens in the areas that were drilled. In addition, the absence of a well-developed feeder zone in the sediment under the sulfide mounds indicates relatively pervasive circulation and diffuse venting of hot fluid over a short period of time rather than long-lived, focused high-temperature discharge. This agrees with the lack of chimneys and the general occurrence of high-temperature pyrrhotite crusts on the sediment as observed during submersible dives (Zierenberg et al., 1994).

\section{IGNEOUS PETROLOGY}

Basaltic rocks were recovered in three holes at Site 1038, Central Hill (Fig. 6): (1) Hole 1038H on the northwest margin of Central Hill (drilled near Holes 1038A and 1038E); (2) Hole 1038I near the top of Central Hill; and (3) Hole 1038G at the southeast margin of Central Hill. The relationships between bathymetry and drill intersections of basalt at $\sim 150$ mbsf suggest this unit is continuous between all three holes. A deep basalt sill/flow was encountered at $403.3 \mathrm{mbsf}$ in Hole 1038I (Fig. 12). Multichannel seismic profiles across Central Hill indicate possible reflectors at the approximate depths of both of these basalts (Davis and Becker, 1994; Zierenberg, et al., 1994).

Hole $1038 \mathrm{G}$ recovered microcrystalline to fine- to mediumgrained basalt at $137.4 \mathrm{mbsf}$ (Fig. 12). The top $14 \mathrm{~cm}$ of Section 1691038G-15X-CC (137.4 to $144.5 \mathrm{mbsf}$ ) recovered (4\% estimated recovery) several small $(0.2$ to $3 \mathrm{~cm}$ diameter) angular fragments of dark blue-gray, unaltered, microcrystalline moderately plagioclasephyric and sparsely olivine-phyric basalt. The basalt fragments are sparsely vesicular (1-3 mm diameter), and vesicles are partly filled with creamy white calcite and possible zeolite(s). Based on thin section observation, the overall texture is variolitic to intersertal and porphyritic. Acicular plagioclase phenocrysts up to $1.5 \mathrm{~mm}$, compose $5 \%$ of the rock (Fig. 13), and 1-mm olivine crystals altered to talc form $<1 \%$ of the rock. The groundmass is composed of cryptocrys-

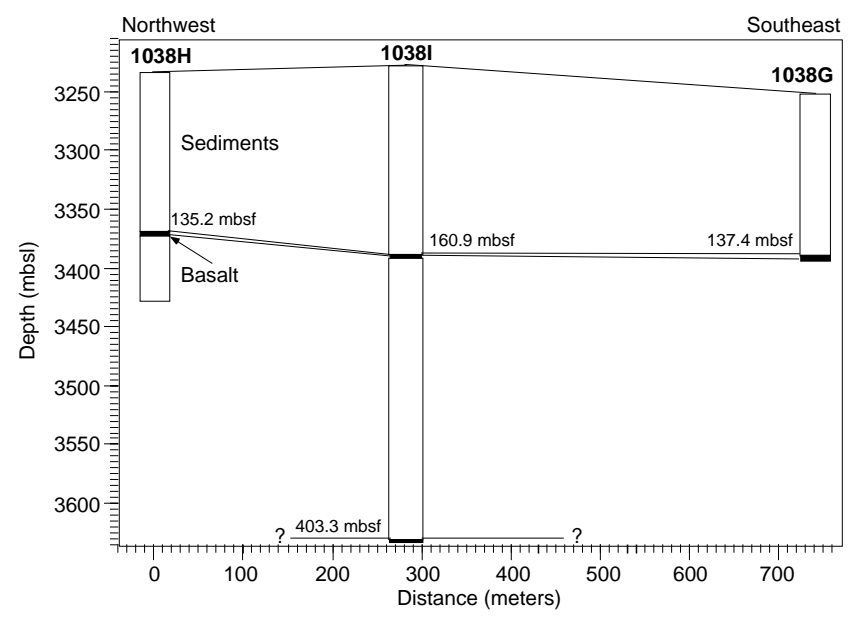

Figure 12. Northwest to southeast section through Central Hill summarizing the true scale relationships between bathymetry and drill intersections of basalt. talline to glassy (formerly) mesostasis $(70 \%)$, very fine-grained acicular plagioclase $(20 \%)$, and 5\% very fine-grained magnetite (Fig. 13). Smectite fills rare, thin $(0.1 \mathrm{~mm})$ crosscutting veins.

Section 169-1038G-16X-1 (144.5-147.0 mbsf) recovered (4\% estimated recovery) dark gray blue, fine- to medium-grained, nonvesicular plagioclase-clinopyroxene-olivine basalt. This basalt is aphyric with a diabasic/subophitic to intersertal texture (Fig. 14). Based on thin-section observation, the groundmass is composed of intergrown plagioclase (50\%), clinopyroxene (20\%), magnetite (trace), and mesostasis (completely altered to smectite/chlorite, Fig. 14). A single $X$-ray fluorescence analysis of this material will be discussed in the context of the basalts cored in the Escanaba Trough Reference Site (see "Igneous Petrology and Geochemistry" section, "Escanaba Trough Reference Site" chapter, this volume). The basalt fragments recovered in Section 169-1038G-15X-CC (Fig. 15) likely represent the chilled margin of the fine to medium-grained basalts recovered in Core 169-1038G-16X (Fig. 14).

Hole $1038 \mathrm{H}$ penetrated microcrystalline basalt at $135.2 \mathrm{mbsf}$ (Fig. 12). Based on drilling conditions, the hard basalt layer is not $>1-2 \mathrm{~m}$ thick. Section 169-1038H-15X-CC (135.2-144.5 mbsf, 1\%

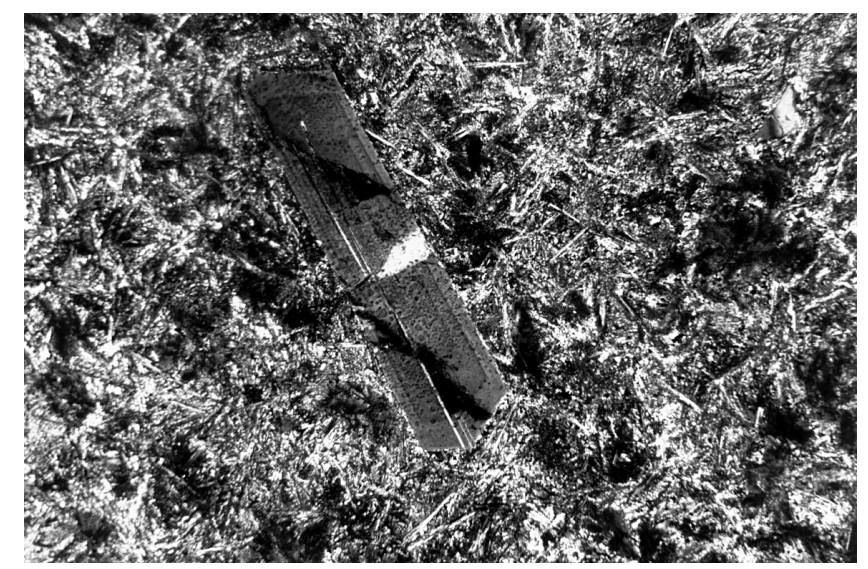

Figure 13. Compositionally zoned plagioclase phenocryst in plagioclasephyric and sparsely olivine-phyric microcrystalline basalt. The groundmass is composed of cryptocrystalline to glassy mesostasis (70\%), very fine grained acicular plagioclase (20\%), and 5\% very fine-grained magnetite (Sample 1038G-15X-CC, 0-3 cm; transmitted and cross-polarized light). Field of view $=1.2 \mathrm{~mm}$ (wide).

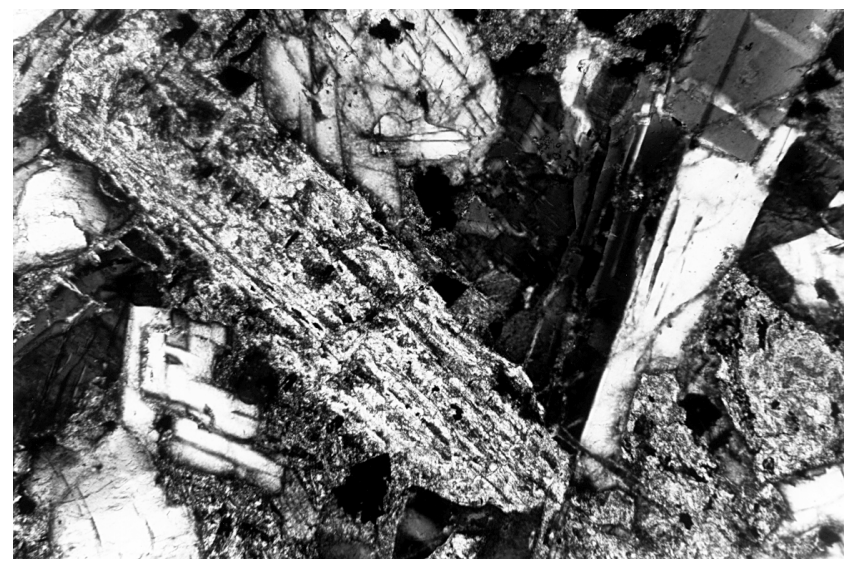

Figure 14. Subophitic to intersertal texture of intergrown clinopyroxene and plagioclase with trace magnetite in a smectite/chlorite altered mesostasis in fine to medium-grained, aphyric, nonvesicular plagioclase-clinopyroxeneolivine basalt (Sample 169-1038G-16X-1, 0-5 cm; transmitted and crosspolarized light). Field of view $=1.2 \mathrm{~mm}$ (wide). 


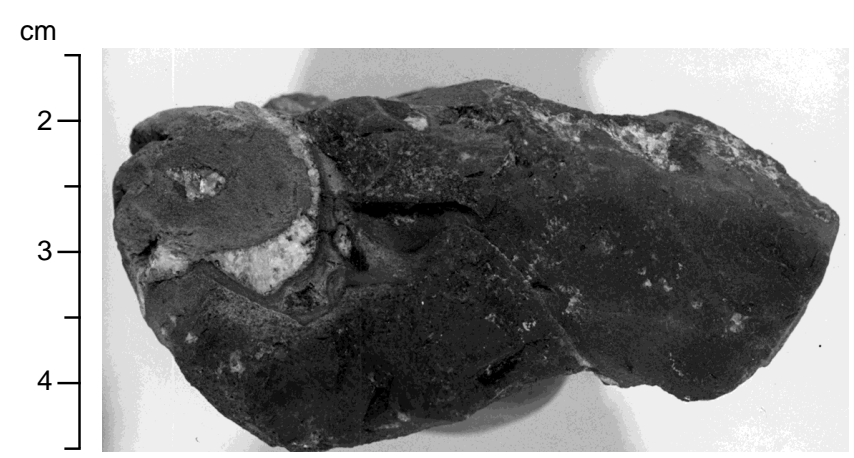

Figure 15 . Microcrystalline, aphyric to sparsely plagioclase-phyric, moderately vesicular (1-3 mm diameter) basalt. Sample contains a bleached and chloritized chilled margin and secondary chlorite, calcite, and pyrite filling voids (interval 169-1038H-15X-CC, $0-4.5 \mathrm{~cm}$ ).

estimated recovery) contains several small (0.2-3 cm diameter), angular fragments of gray, microcrystalline aphyric to sparsely plagioclase-phyric basalt in the recovered $9 \mathrm{~cm}$ of this core. The basalt fragments are sparsely to moderately vesicular (1-3 mm diameter), and vesicles are lined $(0.1-0.5 \mathrm{~mm})$ with medium green chlorite and partly to completely filled with intergrown white calcite and hexagonal plates of pyrite pseudomorphing earlier pyrrhotite. Numerous narrow $(0.2-2 \mathrm{~mm})$ veinlets of chlorite, calcite, and pyrite cut the basalt fragments. Several basalt pieces also contain a contact with adjacent basalt that is bleached and chloritized, imparting a milky green color (Fig. 15). These fragments are from a chilled contact with quenchrelated brecciation and spalling textures. Section 169-1038H-16XCC (144.5-154.4 mbsf) recovered $27 \mathrm{~cm}$ of drilling rubble (2\% estimated recovery), of which $\sim 3 \%$ consists of small angular fragments of gray microcrystalline basalt and $\sim 1 \%$ comprises greenish gray, bleached chloritized basalt with pieces of altered chilled margin. These are similar to basalt fragments in Section 169-1038H-15X-CC. Core 169-1038H-17X (154.9-164.0 mbsf) failed to recover any core; however, 18X (164.0-173.6 mbsf) recovered $6 \mathrm{~cm}$ of drilling rubble $(<<1 \%$ estimated recovery) that included several fragments of basalt similar to those in 16X. Core 169-1038H-19X (173.6-183.6 mbsf) also failed to recover any core, but the top $16 \mathrm{~cm}$ of $20 \mathrm{X}$ (183.6$192.8 \mathrm{mbsf}, 3 \%$ estimated recovery) recovered drilling rubble that included basalt fragments similar to those in $19 \mathrm{X}$. The basalt rubble in Cores $169-1038 \mathrm{H}-18 \mathrm{X}$ and $20 \mathrm{X}$ is probably fall-in from the uppermost intersection of basalt.

Hole 1038I penetrated a 1.5-m-thick interval (based on drilling conditions) of basalt at $\sim 161 \mathrm{mbsf}$ (Fig. 12). Below this, is interbedded noncalcareous to calcareous silty clay and claystone, silt, clayey silt, sand, and very fine to fine sandstone (calcareous and/or micaceous in places). In the very bottom of the hole, $67 \mathrm{~cm}$ of basalt was recovered (Section 169-1038I-43X-3, 403.3-404.0 mbsf).

Section 169-1038I-18X-CC (160.9-170.5 mbsf, 4\% estimated recovery) recovered numerous small $(0.2-3 \mathrm{~cm}$ diameter), angular fragments of gray cryptocrystalline to very fine-grained, aphyric to sparsely plagioclase-phyric basalt in the bottom $14 \mathrm{~cm}$ of the total recovered $40 \mathrm{~cm}$. The basalt fragments can be classified into two types. The first type consists of gray, very fine-grained, nonvesicular, sparsely plagioclase phyric basalts (phenocrysts to $2 \mathrm{~mm}$ ); most fragments are of this type. The second type consists of gray, cryptocrystalline aphyric, moderately vesicular basalts. Vesicles are $1-5 \mathrm{~mm}$ in diameter, lined with green clay $(0.1-0.5 \mathrm{~mm})$, and filled with finegrained, subhedral to euhedral calcite, pyrite, and pyrrhotite. One piece is cryptocrystalline, slightly lighter gray than the others, and displays quenched textures (possible chilled margin). A narrow (0.2 $\mathrm{mm}$ ) fracture fill veinlet of pyrite with a bleached envelope cuts one of the basalt fragments. Section 169-1038I-20X-CC recovered drill- ing rubble of silicified claystone and siltstone, massive sulfide, and basalt; the basalt is likely fall-in from Section 169-1038I-18X-CC.

Section 169-1038I-43X-3 (401.4-404.0 mbsf, 87\% estimated recovery) recovered $67 \mathrm{~cm}$ of very fine-grained, nonvesicular to sparsely vesicular, sparsely to moderately plagioclase-olivine-phyric and plagioclase-phyric basalt, with phenocrysts $0.5-1 \mathrm{~mm}$ in diameter. The upper contact contains a 2-mm-thick baked and bleached sediment margin, and the basalt has $\mathrm{a} \approx 5$-mm-thick margin of fresh glass. Several pieces of basalt contain millimeter-sized white to orange calcite amygdules and subvertical veins of calcite $(0.5-1 \mathrm{~mm})$, some of which contain fine-grained pyrite selvages; pyrite is also finely disseminated in one piece.

The pillow and lobate basalt flows that occur to the east of Central Hill (see Fig. 6) are at a higher level than these cored basalts. Furthermore, geochemical evidence indicates that the pore waters in the immediate vicinity of the cored basalts have reacted at high temperatures (see "Inorganic Geochemistry" section, this chapter). The upper basalt intersections in these three holes could therefore be interpreted as part of a single thin $(<10 \mathrm{~m})$ sill.

The basalt intersection in the base of Hole 1038I could be interpreted to be a flow, based on the presence of fresh glass. However, there was a very narrow $(2 \mathrm{~mm})$ rim of baked sediment at the upper contact. The lack of a definitive high temperature geochemical signature in pore waters in the adjacent sediments can be interpreted to indicate that the basalt was a flow (see "Inorganic Geochemistry" section, this chapter). There is insufficient core penetration from this interval to ascertain if this is igneous basement.

\section{STRUCTURAL GEOLOGY}

The structural objectives of drilling the Central Hill hydrothermal site were to determine the permeability and structural controls on hydrothermal fluids creating sulfide mounds and to determine the relationship between faulting and fluid flow. Surprisingly, few hydrothermal veins and structures were recovered from the nine holes drilled at Site 1038. Despite the paucity of structural data from Holes $1038 \mathrm{G}, 1038 \mathrm{H}$, and 1038I (Table 7), some conclusions can be made on focused and porous hydrothermal fluid flows, based on the regional geology and the analysis of unaltered and undeformed sediments.

\section{Holes 1038A-1035F}

No tectonic structures were recovered in Holes 1038A through 1038F. Sedimentary bedding dips within $2^{\circ}$ to $3^{\circ}$ of horizontal. The apparent lack of hydrothermal veining and alteration indicates that fluid flow through the sediments is weak and that no extensive structurally controlled fluid flow network has developed.

\section{Hole 1038G}

One vertical calcite vein, $2 \mathrm{~mm}$ wide, was recovered in the core catcher of Core 169-1038G-4H and extended through $10 \mathrm{~cm}$ of the core.

\section{Hole 1038H}

Discrete pieces of clayey siltstone within the first three cores of Hole $1038 \mathrm{H}$ exhibit fine fracture networks $<1 \mathrm{~mm}$ wide with no hydrothermal mineralization. Also, within Section 169-1038H-1X-2, chlorite alteration occurs along surfaces of drilling pieces indicating that chlorite alteration was initially fracture controlled. Chlorite alteration becomes pervasive throughout silty sandstone downcore in Section 169-1038H-1X-3, with more extensive alteration occurring along fractured surfaces. The pieces with fine fracture networks and no alteration may represent the initial stage of localized fluid flow. 
Table 7. Summary of structural features, Holes $1038 \mathrm{G}$ and $1038 \mathrm{H}$.

\begin{tabular}{|c|c|c|c|c|c|c|c|c|c|c|c|c|}
\hline \multirow[b]{2}{*}{$\begin{array}{c}\text { Core, } \\
\text { section }\end{array}$} & \multicolumn{3}{|c|}{ Feature } & \multicolumn{2}{|c|}{ Position } & \multicolumn{3}{|c|}{ Veins } & \multirow{2}{*}{$\begin{array}{l}\text { Apparent dips } \\
\text { App Dip/ Dir1 }\end{array}$} & \multicolumn{2}{|c|}{ Calculated } & \multirow[b]{2}{*}{ Comments } \\
\hline & $\begin{array}{l}\text { Depth } \\
\text { (mbsf) }\end{array}$ & Oriented & Identifier & $\begin{array}{l}\text { Top } \\
(\mathrm{cm})\end{array}$ & $\begin{array}{l}\text { Bottom } \\
(\mathrm{cm})\end{array}$ & Mineralogy & $\begin{array}{l}\text { Width } \\
(\mathrm{mm})\end{array}$ & Wall rock & & Strike & Dip & \\
\hline $\begin{array}{l}\text { 169-1038G- } \\
4 \mathrm{H}-\mathrm{CC}\end{array}$ & 42.22 & $\mathrm{Y}$ & V & 40 & 51 & $\mathrm{Cc}$ & 2 & SED & & 120 & 90 & \\
\hline $169-1038 \mathrm{H}-$ & & & & & & & & & & & & \\
\hline $1 \mathrm{X}-2$ & 2 & $\mathrm{~N}$ & $\mathrm{~F}$ & 50 & 60 & & & SED & & & & 15 -mm offset on reverse fault. \\
\hline $1 \mathrm{X}-2$ & 2.5 & $\mathrm{~N}$ & $\mathrm{~F}$ & 100 & 107 & & & SED & & & & $\begin{array}{l}\text { Chlorite alteration occurs along the rim of piece; likely } \\
\text { fracture. }\end{array}$ \\
\hline $2 X-2$ & 14 & $\mathrm{~N}$ & D & 60 & 68 & & & SED & & & & $\begin{array}{l}\text { Sandstone clastic dike } 5-6 \mathrm{~mm} \text { near vertical } \\
\text { orientation, but disrupted by drilling. }\end{array}$ \\
\hline $2 X-2$ & 14.4 & $\mathrm{~N}$ & $\mathrm{D}$ & 100 & 118 & & & SED & & & & $\begin{array}{l}\text { Sandstone clastic dike } 1 \mathrm{~cm} \text { wide; orientation disrupted } \\
\text { by drilling. }\end{array}$ \\
\hline $3 \mathrm{X}-1$ & 21.84 & $\mathrm{~N}$ & $\mathrm{~F}$ & 34 & 39 & & & SED & & & & Fine network of sedimentary, nonmineralized fractures. \\
\hline $3 X-1$ & 22.75 & $\mathrm{Y}$ & V & 125 & 136 & Py & 1 & SED & & 074 & 90 & Extension fracture. \\
\hline $3 \mathrm{X}-2$ & 23.25 & $\mathrm{~N}$ & $\mathrm{~F}$ & 25 & 30 & & & SED & & & & Fine network of fractures with sedimentary infilling. \\
\hline $3 X-2$ & 24.12 & $\mathrm{Y}$ & $\mathrm{V}$ & 112 & 120 & Py & 2 & SED & $64 / 270$ & & & \\
\hline
\end{tabular}

Note: $\mathrm{Y}=$ oriented, $\mathrm{V}=$ vein, $\mathrm{Cc}=$ calcite, $\mathrm{SED}=$ sediments, $\mathrm{N}=$ not oriented, $\mathrm{F}=$ fault with offset, $\mathrm{D}=$ clastic dike, and $\mathrm{Py}=$ pyrite.

Only part of this table is produced here. The entire table appears on CD-ROM.

Pore-fluid pressures may have exceeded lithostatic pressure and induced fracturing. Fluids could then flow along the fracture networks preferentially altering the fracture surfaces.

In Section 169-1038H-2X-2, three 6- to 10-mm-wide clastic sandstone dikes occur within silty clay. These dikes are disaggregated and broken by drilling so that no consistent orientation could be determined.

Two 1- to 2-mm-wide extension fractures filled with pyrite occur in Sections 169-1038H-3X-1 and 2. These subvertical fractures represent the first structurally controlled sulfide hydrothermal features recovered within the Escanaba sites.

\section{Hole 1038I}

One subvertical fracture with no hydrothermal mineralization was recovered immediately above basalt within the silty claystone of Section 169-1038I-43X-2. No offset could be determined on this fracture, but slickenlines on the fracture surface indicate dip slip movement. Six subvertical calcite and zeolite veins $<2 \mathrm{~mm}$ wide occur within the basalt recovered in Section 169-1038I-43X-3. These carbonate veins crosscut fractures with no hydrothermal mineralization. The fractures may be the result of thermal contraction of the basalt as it intruded sediments.

\section{Conclusions}

The lack of abundant, structurally controlled hydrothermal features and hydrothermally altered sediments recovered from holes drilled at Site 1038 indicates that no pervasive hydrothermal circulation around the Central Hill hydrothermal site has developed. The small sulfide mounds localized around Central Hill are interpreted to be structurally controlled by extensional faulting associated with basalt intrusions (Fig. 6; Zierenberg et al., 1994). Structural control of sulfide mineralization is not evident from core observations, which may indicate that the primary fluid conduits or bounding faults may be sealed to lateral fluid migration. Faults sealed to the sediment layers would effectively limit the extent of hydrothermal alteration in the sediments, but would still allow for the production of surface sulfide mounds.

\section{INORGANIC GEOCHEMISTRY}

Pore-water samples were collected from the two active hydrothermal fields present on Central Hill: a higher temperature area on the northwest flank of the hill (Holes 1038A, 1038B, 1038C, 1038D, $1038 \mathrm{E}$, and $1038 \mathrm{H})$ and an area of diffusive low temperature venting on the southeast flank (Holes 1038F and 1038G). Hole 1038I was drilled at the top of Central Hill between these two areas of venting. Chemical data indicate that the hydrothermal vent areas around Central Hill are part of a single hydrothermal system hydrologically interconnected at depth. In addition, geological observations suggest that all hydrothermal deposits on Central Hill are of similar age (Zierenberg et al., 1994; Campbell, et al., 1994).

Holes 1038A through 1038F were drilled using the RCB system, and were targeted to recover massive sulfides exposed at the sea floor. Recovery of these holes was generally low, and sediment suitable for squeezing was not recovered at shallow depths. Holes $1038 \mathrm{G}$ through $1038 \mathrm{I}$ were drilled using the APC/XCB system to explore the hydrothermal alteration and pore-fluid geochemistry. In these holes, pore-water samples were collected at close intervals.

Chemical analysis of the fluid samples was conducted following Gieskes et al. (1991), except for the determination of Na concentration. The Na concentration was determined by ion chromatography instead of charge-balance calculation. For several samples, the amount of pore fluid available was insufficient to determine alkalinity, and it was impossible to calculate charge balance. Results of the ion chromatographic analysis were corrected for baseline drift during the measurement based on comparison with values determined by charge-balance calculation.

The data on the pore-water compositions from Site 1038 are reported in Table 8 . The chemical compositions of pore fluids in each area are discussed as to their possible sources, as well as the alteration reactions that may have affected the pore-fluid chemistry.

\section{Results and Discussion}

\section{High-Temperature Venting Area (Holes 1038A, 1038E, and 1038H)}

Hole 1038A was drilled on the sulfide mound from which $217^{\circ} \mathrm{C}$ hydrothermal fluids were sampled in 1988 (Figs. 1, 6). The hole was sited only 1-2 m away from marker 6X left during Alvin dive 2036 beside one of the hot vents. This site was located near the top of northwestern flank of Central Hill. Hole 1038A was drilled to 114.5 mbsf. Three samples were recovered from a sand layer between 70 and 115 mbsf. Hole $1038 \mathrm{E}$ was located $28 \mathrm{~m}$ south of Hole 1038A. Hole $1038 \mathrm{E}$ hole was drilled to $40.6 \mathrm{mbsf}$ and was terminated after the massive sulfide mound was penetrated. Recovery in the upper part of the hole was very low, and only one sample from a sand layer was provided for pore-water study. Hole $1038 \mathrm{H}$ was drilled $21 \mathrm{~m}$ 
Table 8. Chemical composition of pore fluids, Site 1038.

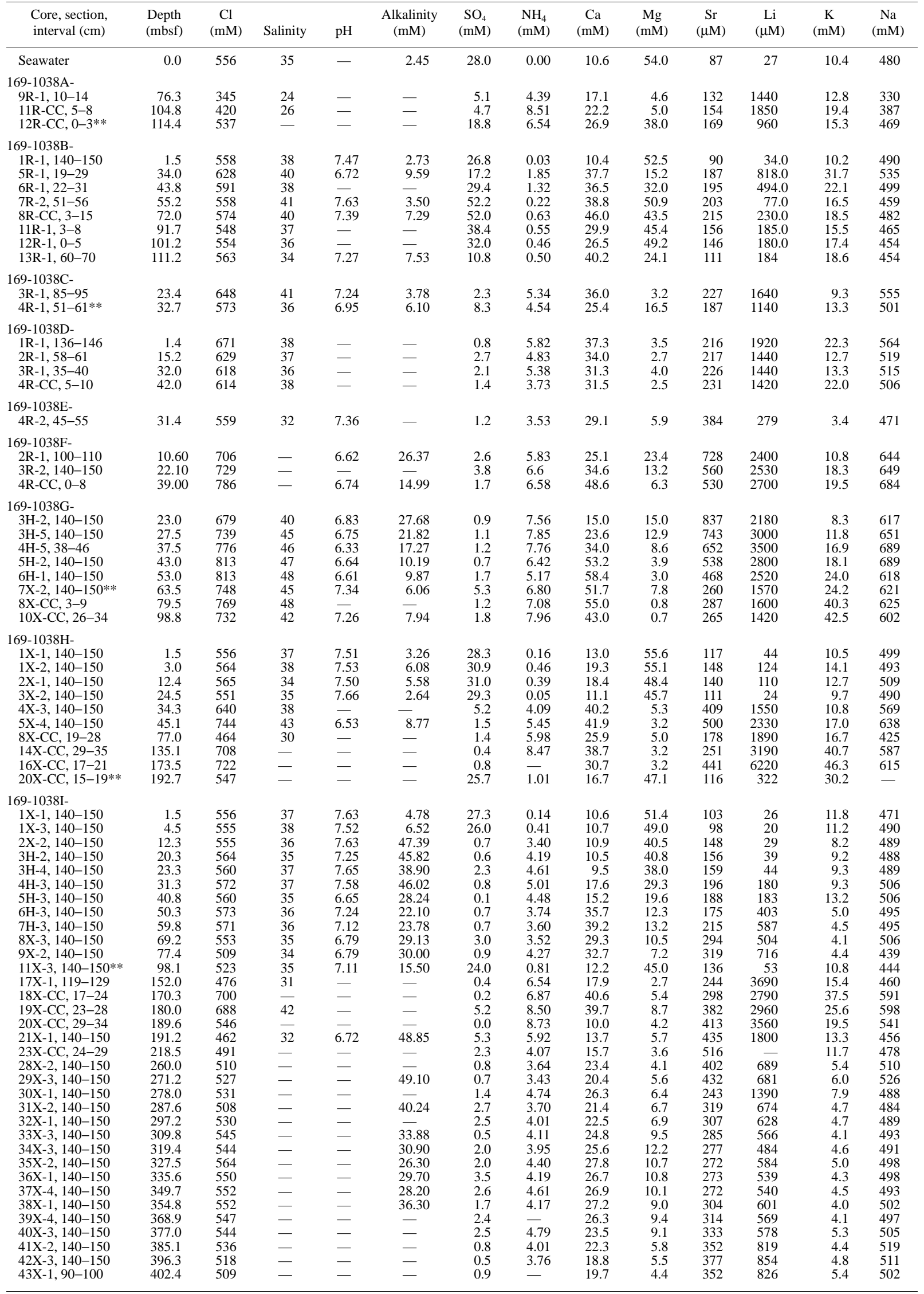

Notes: $-=$ no data. $* *=$ contaminated samples. 
Table 8 (continued).

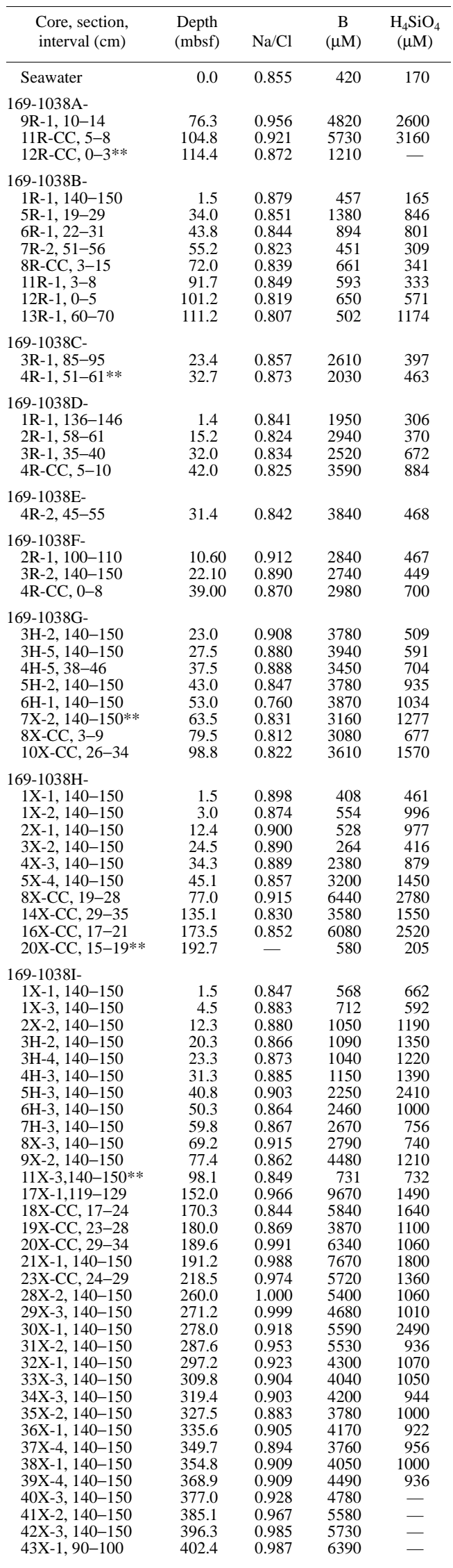

south of Hole 1038A and $10 \mathrm{~m}$ northwest of Hole 1038E. Hole $1038 \mathrm{H}$ was drilled to $193 \mathrm{mbsf}$ and sampled basalt at a depth of $\sim 135$ mbsf.

The chemical composition of the pore fluids from holes drilled near the high-temperature vents on northeast flank of the hill are plotted vs. depth in Figure 16 (Holes 1038A, 1038E, and 1038H). The sample from 114.4 mbsf of Hole 1038A (Section 169-1038A-12RCC) showed elevated $\mathrm{Mg}$ and $\mathrm{SO}_{4}$ concentrations that seem to indicate contamination by seawater. Data from this sample are not plotted in the profiles and are excluded from the following discussion.

The pore-fluid compositional profiles show drastic changes in all the dissolved species. Discontinuities in the profiles are evident at depths of 25, 40-80, and 100-120 mbsf.

Above $24.5 \mathrm{mbsf}$, pore fluids have compositions similar to that of seawater, suggesting seawater recharge. Slight increases in $\mathrm{Ca}$ and $\mathrm{K}$ concentrations and a slight decrease in $\mathrm{Mg}$ concentration are attributed to smectite-forming alteration.

Below $24.5 \mathrm{mbsf}$, the concentrations of $\mathrm{Mg}$ and $\mathrm{SO}_{4}$ are close to zero. Moreover, the high $\mathrm{Na}(\sim 600 \mathrm{mM})$ and $\mathrm{Cl}(\sim 750 \mathrm{mM})$ concentrations $40 \mathrm{mbsf}$ and below $130 \mathrm{mbsf}$, and the low $\mathrm{Na}$ and $\mathrm{Cl}(<400 \mathrm{mM})$ concentrations at $\sim 80 \mathrm{mbsf}$ are remarkable. Because any alteration reactions are unlikely to explain such a large discrepancy in $\mathrm{Na}$ and $\mathrm{Cl}$ concentrations from that from seawater, these pore-fluid signatures are interpreted to indicate contributions from a hydrothermal component that has experienced subcritical phase separation. The existence of low-chlorinity fluids between 80 and $100 \mathrm{mbsf}$ corresponds to the location of a coarse-grained, highly permeable sand layer (Unit III, see "Lithostratigraphy and Sedimentology" section, this chapter), implying that the vapor-rich component of the phase separated fluid escapes through this porous layer.

In the deeper layers, $\mathrm{K}, \mathrm{Li}$, and $\mathrm{Sr}$ concentrations increase with depth. This appears to be related to the basaltic rock cored at a depth of 161 mbsf. This unit may be a basaltic sill, and the change in pore fluid is interpreted to be related to reactions driven by the heat of intrusion. Alternatively, this unit may be an older basalt flow that influences the movement of subsurface fluids.

\section{Northern Area (Holes 1038C, and 1038D)}

Holes $1038 \mathrm{C}$ and $1038 \mathrm{D}$ are separated by $\sim 72 \mathrm{~m}$ and were drilled on the northern slope of Central Hill, where a nearly continuous outcrop of massive sulfide is exposed. No active fluid emanation was observed in this area during either dive or camera surveys before drilling. However, recent hydrothermal activity is suggested by the presence of fresh sulfide at the surface and by the observation of small patches of bacterial mat and clams. Hole $1038 \mathrm{C}$ was drilled to 41.8 mbsf, and two pore-water samples were recovered. Hole 1038D was drilled to $43.8 \mathrm{mbsf}$ and four pore-water samples were recovered.

The chemical composition of pore fluids is plotted vs. depth in Figure 17. The data from Hole 1038C and 1038D are plotted together, along with the composition of seawater for comparison. The sample from 32.7 mbsf of Hole 1038C (Section 169-1038C-4R-1) showed elevated $\mathrm{Mg}$ and $\mathrm{SO}_{4}$ concentrations and seems to indicate contamination from seawater. Data from this sample are not plotted in the profiles and are excluded from the discussion.

Pore fluids in these holes are dominated by a hydrothermal component over all sampling depths. Significant depletions in $\mathrm{Mg}$ and $\mathrm{SO}_{4}$, and enrichments in cations $(\mathrm{K}, \mathrm{Li}, \mathrm{Ca}$, and $\mathrm{Sr})$ and organic matter-derived species $\left(\mathrm{NH}_{4}\right.$ and $\left.\mathrm{B}\right)$ are consistent with the chemical signature of a hydrothermal component. $\mathrm{Na}$ and $\mathrm{Cl}$ concentrations higher than those of seawater $(\mathrm{Na} \sim 560 \mathrm{mM}$ and $\mathrm{Cl} \sim 670 \mathrm{mM})$ suggest that a brine-rich hydrothermal component dominates the pore fluids. It is remarkable that the hydrothermal component is present at such a shallow depth beneath sulfide outcrops without present hydrothermal venting at the seafloor. 
Figure 16. Profiles of pore-water composition at the high-temperature vent area on the northern flank of Central Hill. A. Open symbols $=\mathrm{Cl}$, and solid symbols $=\mathrm{Na}$. B. Mg. C. Ca. D. $\mathrm{SO}_{4}$. E. K. F. Sr. G. B. H. $\mathrm{NH}_{4}$. Circles $=$ Hole $1038 \mathrm{~A}$, squares $=$ Hole $1038 \mathrm{E}$, and triangles $=$ Hole $1038 \mathrm{H}$.

Figure 17. Profiles of pore-water composition on the northwestern flank of Central Hill. A. Open symbols = $\mathrm{Cl}$, and solid symbols = Na. B. Mg. C. Ca. D. SO 4 . E. K. F. Li. G. B. H. $\mathrm{NH}_{4}$. Circles $=$ Hole 1038D, squares $=$ Hole $1038 \mathrm{C}$, and diamonds $=$ seawater.

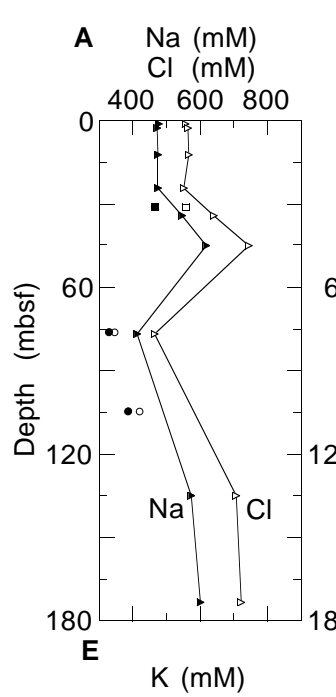

$\begin{array}{cccc}\text { B } & & \\ & \mathrm{Mg}(\mathrm{mM}) \\ 0 & 20 & 40 & 60\end{array}$

C $\mathrm{Ca}(\mathrm{mM})$

D $\mathrm{SO}_{4}(\mathrm{mM})$

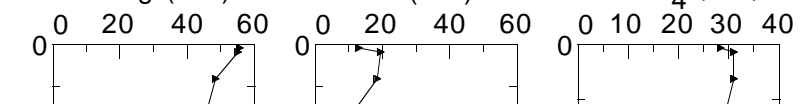

$20 \quad 40 \quad 60$
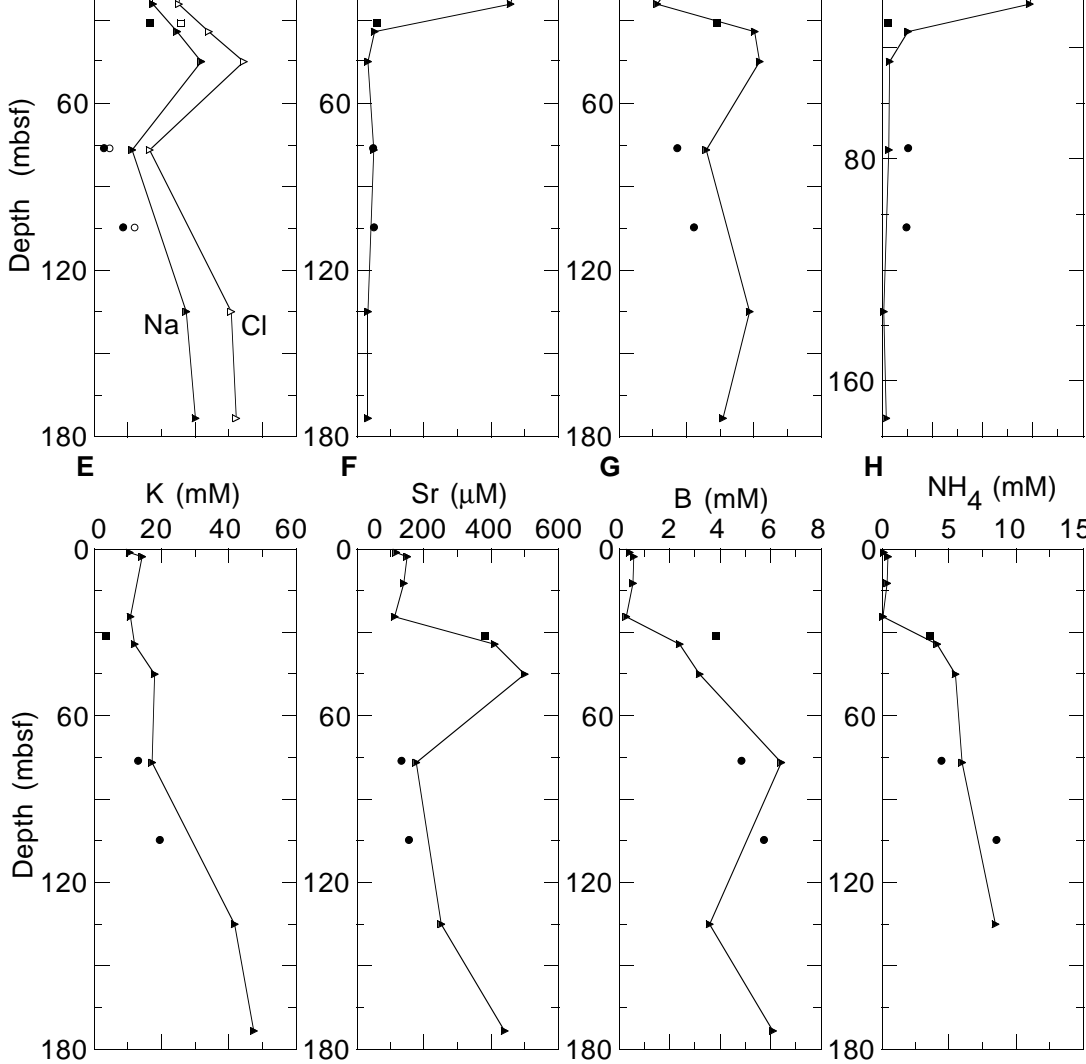

46
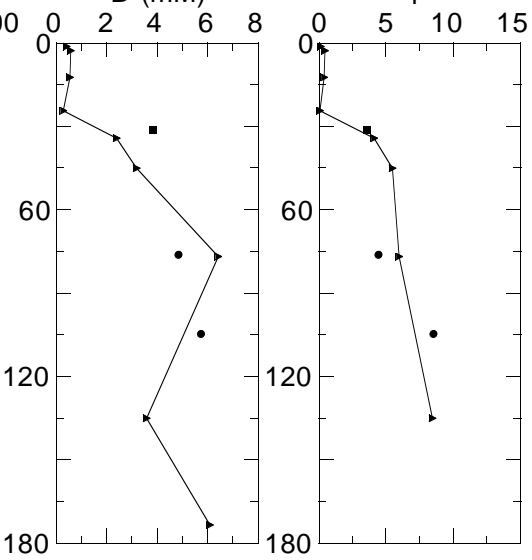

D $\mathrm{SO}_{4}(\mathrm{mM})$
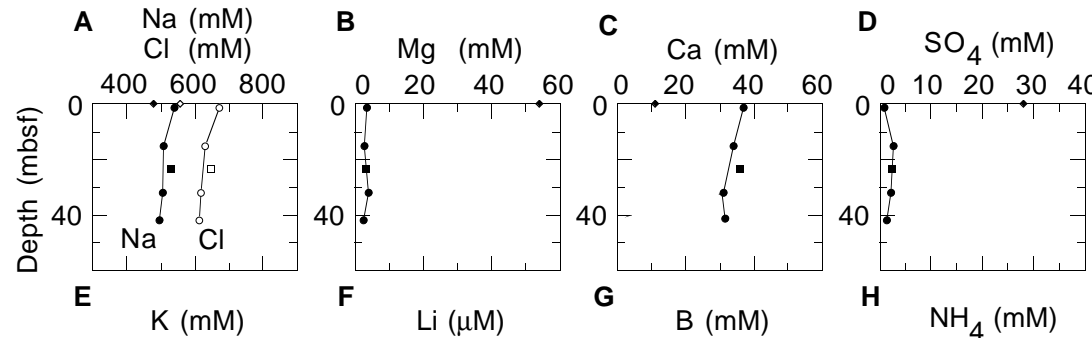

H

$\mathrm{NH}_{4}(\mathrm{mM})$

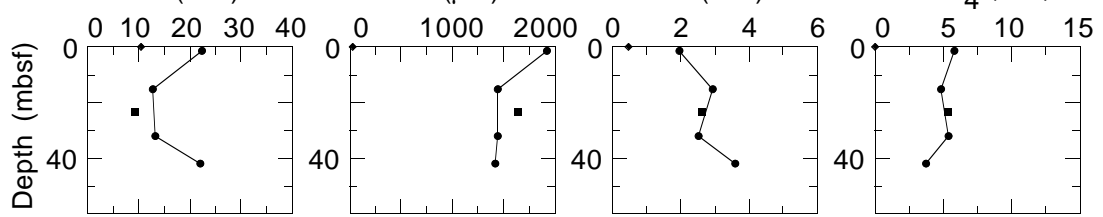

\section{Western Area (Hole 1038B)}

Hole $1038 \mathrm{~B}$ was drilled into a small mound where $108^{\circ} \mathrm{C}$ fluids were sampled in 1988 (Fig. 6). This mound is located on the northwestern slope of Central Hill, 260 m west of Hole 1038A. Hole 1038B was drilled to 120.5 mbsf. Eight pore-fluid samples were recovered. However, no sediment suitable for squeezing was recovered at shallow depths (2 to $34 \mathrm{mbsf}$ ). The chemical composition of the pore fluids is plotted as a profile vs. depth in Figure 18.

A marked increase in the $\mathrm{SO}_{4}$ concentration (up to $50 \mathrm{mM}$ ) of the pore fluids occurs below $50 \mathrm{mbsf}$. This is accompanied by an increase in $\mathrm{Sr}$ and $\mathrm{Ca}$, consistent with the dissolution of anhydrite. Although anhydrite is not observed in the sediments at these depths (see "Lithostratigraphy and Sedimentology" section, this chapter), similar effects caused by anhydrite dissolution commonly occur in pore fluids in other hydrothermal areas (see "Inorganic Chemistry" section, "Middle Valley: Bent Hill Area" and "Middle Valley: Dead Dog" chapters, this volume), and only an imperceptible amount of finely disseminated anhydrite dissolution is needed to produce the observed chemical affects.

Between 30 and $50 \mathrm{mbsf}$, there is an increase in $\mathrm{Mg}$ from $\sim 12 \mathrm{mM}$ toward seawater values $(54 \mathrm{mM})$ that is accompanied by a drop in $\mathrm{Cl}$, $\mathrm{Na}, \mathrm{K}, \mathrm{Li}, \mathrm{B}$, and $\mathrm{NH}_{4}$ concentrations from values greater than seawater, to values close to seawater. This relationship strongly suggests 


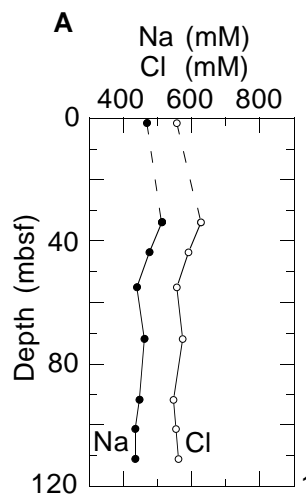

E

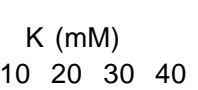

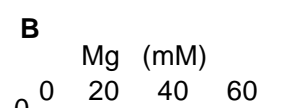

\section{C}

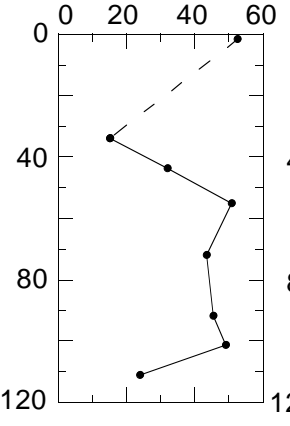

$\mathbf{F}$
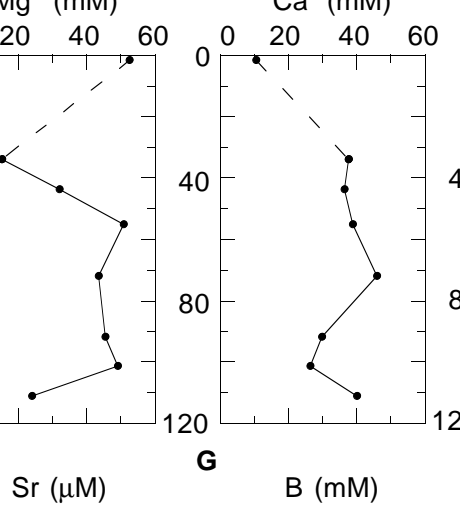

G
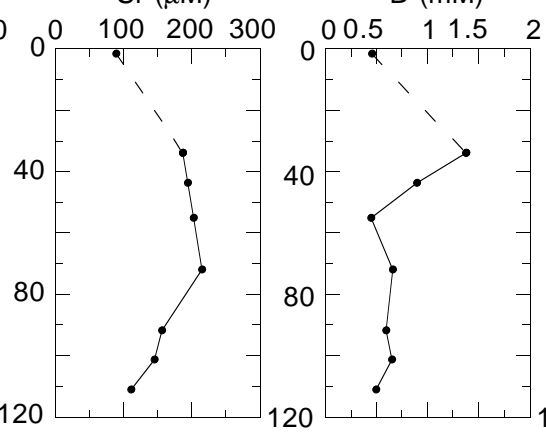

D

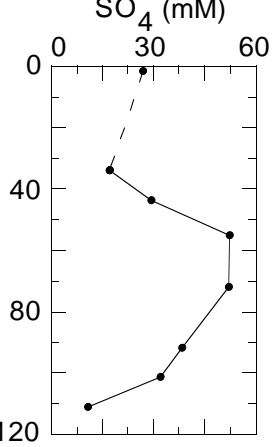

H

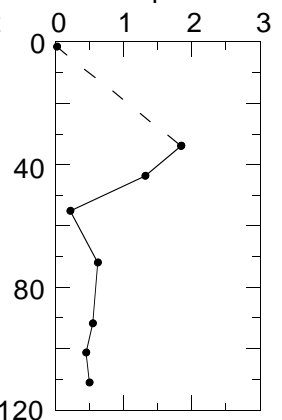

Figure 18. Profiles of pore-water composition in the vicinity of the vent where $108^{\circ} \mathrm{C}$ fluid was sampled in 1988. A. Open circles $=\mathrm{Cl}$, and solid circles $=\mathrm{Na}$. B. $\mathrm{Mg}$. C. Ca. D. $\mathrm{SO}_{4}$. E. K. F. Sr. G. B. H. $\mathrm{NH}_{4}$. Dashed lines $=$ interval with no samples. mixing between a hydrothermal component in the upper silty clay layers (6-34 mbsf) and the ambient pore fluids that dominate the deeper layer.

Between 60 and 100 mbsf, pore fluids generally show a uniform composition, although anhydrite dissolution appears to cause a more irregular variation in $\mathrm{Sr}, \mathrm{Ca}$, and $\mathrm{SO}_{4}$ concentrations. Concentrations of $\mathrm{Cl}$ and $\mathrm{Mg}$ are close to those of seawater in these layers. The small reduction in $\mathrm{Na}$ concentration, and the increase in $\mathrm{K}, \mathrm{Li}, \mathrm{B}$, and $\mathrm{NH}_{4}$ concentrations compared to seawater values may be attributed to in situ sediment alteration and the decomposition of organic material.

Anhydrite concretions were observed in the sediments below 111 mbsf, and the sediments are altered (see "Lithostratigraphy and Sedimentology" section, this chapter). The one pore-fluid sample at this depth shows a significant decrease in $\mathrm{Mg}$ and an increase in $\mathrm{Ca}$ (which is not accompanied by an increase in $\mathrm{SO}_{4}$ ). This suggests that this depth horizon represents the base of the recharge zone and that hydrothermal alteration reactions in this layer or below modify the $\mathrm{Ca}$ and $\mathrm{Mg}$ profiles.

\section{East Side of Central Hill (Holes 1038F and 1038G)}

On the southeastern side of the Central Hill, sulfide mineralization and vent specific fauna were observed during the submersible dive studies (Zierenberg et al., 1994). Hole $1038 \mathrm{~F}$ was drilled to 38.4 mbsf, and three pore-fluid samples were recovered. Hole $1038 \mathrm{G}$ is located $\sim 9$ north and was drilled to $147.0 \mathrm{mbsf}$, and eight pore fluid samples were recovered.

The chemical composition of the pore fluids is plotted as a profile vs. depth in Figure 19. The profiles from Hole 1038F and 1038G are shown together. The chemical composition of the sample from 63.5 mbsf (Section 169-1038G-7X-2) showed elevated $\mathrm{Mg}$ and $\mathrm{SO}_{4}$ concentrations that seem to indicate contamination from seawater. Data from this sample are not plotted in the profiles and are excluded from following discussion.

The most remarkable features of the pore fluids are high $\mathrm{Na}$ and $\mathrm{Cl}$ concentrations $(\mathrm{Na}>600 \mathrm{mM}$ and $\mathrm{Cl}>800 \mathrm{mM})$. They are attrib- uted to a contribution from a hydrothermal component that has boiled, resulting in increased salinity because of vapor loss.

Profiles of major elements ( $\mathrm{Na}, \mathrm{Cl}, \mathrm{Ca}, \mathrm{Mg}$, and $\mathrm{K}$ ) above $40 \mathrm{mbsf}$ are generally explained by mixing between this hydrothermal component and seawater. Slight differences between the profiles of Hole $1038 \mathrm{~F}$ and $1038 \mathrm{G}$ may be attributed to a difference in depths of seawater entrainment. The depletion of $\mathrm{SO}_{4}(<5 \mathrm{mM})$ and a significant high alkalinity (up to $25 \mathrm{mM}$ ) strongly suggest that sulfate reduction occurs within the shallow horizons.

The $\mathrm{K}$ concentration increases and the $\mathrm{Li}$ and $\mathrm{Sr}$ concentrations decrease with depth below $\sim 60 \mathrm{mbsf}(1038 \mathrm{H})$. The Ca concentration also shows depletion in the deepest sample. These changes in porefluid chemistry may be related to chloritization caused by the reaction with basalt, which was encountered at 137 mbsf in Hole 1038G. In addition, chloritization is evident in the sediments recovered from below 62 mbsf in Hole 1038G (see "Lithostratigraphy and Sedimentology" section, this chapter).

\section{Summit of Central Hill (Hole 1038I)}

Hole 1038I was drilled at the top of Central Hill in $3215 \mathrm{~m}$ water depth to document the history of sedimentation and of sediment alteration for comparison with the "Escanaba Reference Trough Site" chapter (Hole 1037B, Fig 1). The hole is away from the upflow zones visible at the surface, although the steep temperature gradients indicate subsurface circulation of hot fluid. The hole was drilled to a depth of $403.2 \mathrm{mbsf}$, and a total of 33 pore-fluid samples were obtained. The lithologic units encountered include Unit II, interbeded fine-grained turbidites and hemipelagic muds, 0-75.9 mbsf; Unit III, sand-rich turbidites with minor hemipelagic muds, 75.9-103.7 mbsf; Unit IV and V, fine- to medium-grained sand turbidites with siltstone an claystone, 141.7-180.1 mbsf; Unit VI, carbonate altered turbidites and hemipelagites, 180.1-287.0 mbsf; Unit VII, calcareous silty clay with minor silty turbidites, 287.0-371.1; and Unit VIII, calcareous fine-grained sand to silt turbidites, 371.1-403.2 mbsf. In addition, basalt occurs at 161.1-162.6 mbsf, and the hole terminated in basalt 
Figure 19. Profiles of pore-water composition on the southeast flank of Central Hill. A. Open symbols $=\mathrm{Cl}$, and solid symbols = Na. B. Mg. C. Ca. D. $\mathrm{SO}_{4}$. E. K. F. alkalinity. G. B. H. $\mathrm{NH}_{4}$. Circles $=$ Hole 1038F, and squares $=$ Hole $1038 \mathrm{G}$.

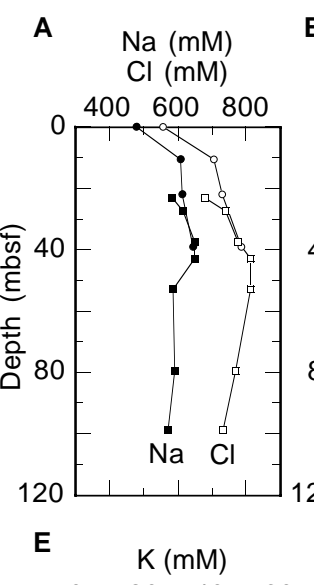

B $\mathrm{Mg}(\mathrm{mM}) \quad$ C

\section{C}

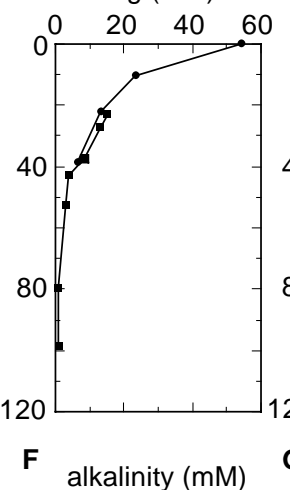

$\mathrm{G}$
D

$\mathrm{SO}_{4}(\mathrm{mM})$

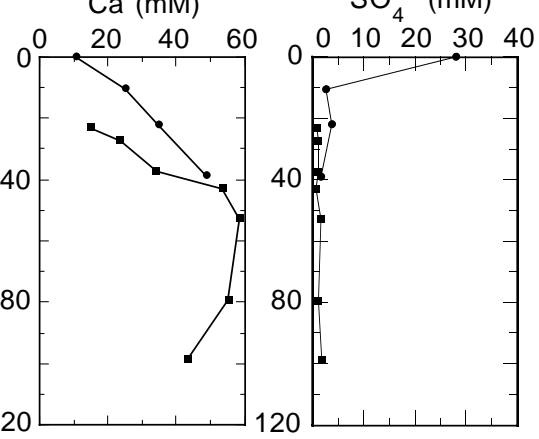

H $\quad \mathrm{NH}_{4}(\mathrm{mM})$

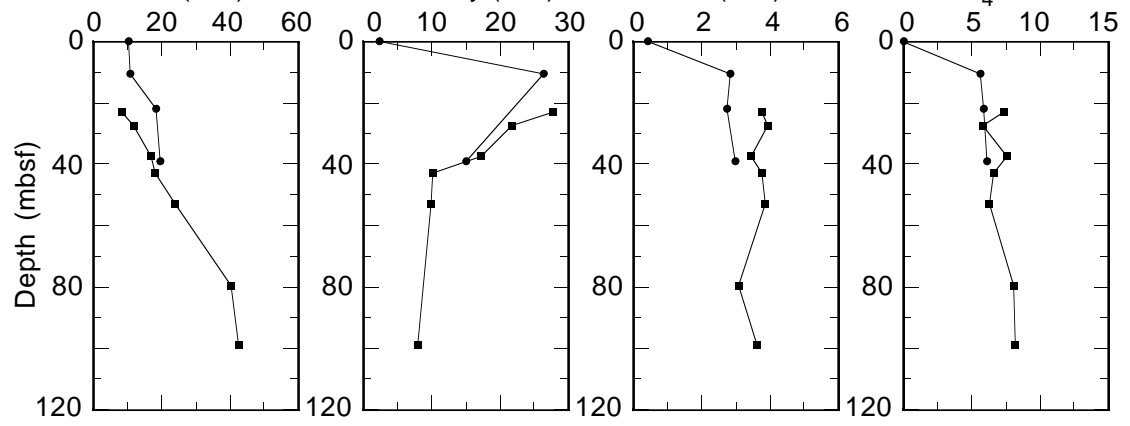

The concentration depth profile of $\mathrm{K}$ is dominated by a sharp peak

from 403.2 to $404.0 \mathrm{mbsf}$. The pore-fluid sampling density was rather sparse in the interval 75.9-103.1 mbsf (lithologic Unit III) as many sand layers were encountered, and no core was recovered in the 103.1-141.7 mbsf interval.

The chemical composition of the fluids is given in Table 8 and plotted as profiles vs. depth in Fig. 20. Because of the large changes in pore-fluid concentrations of several elements in the vicinity of the upper basalt ( 161 mbsf; see "Lithostratigraphy and Sedimentology" section, this chapter), some of the smaller features in the concentration depth profiles in the lower part of the sediment column are not apparent. Expanded scale concentration depth profiles below 300 mbsf have been plotted in Fig. 21. One sample is contaminated with seawater (Section 169-1038I-11X-3) and is included in the table for completeness, although it is not included in the figures.

\section{Alkali Elements}

Concentrations of $\mathrm{Na}$ are similar to seawater in the upper $75 \mathrm{~m}$ of the sediment column, but decrease sharply in the sandy interval (lithologic Unit III). There is a sharp increase in the Na content of the pore fluids immediately below the upper basalt, with concentrations of $\mathrm{Na}$ exceeding $600 \mathrm{mM}$. Below the basalt, $\mathrm{Na}$ increases with depth between 200 and 280 mbsf. Below $280 \mathrm{mbsf}$, the Na content of the pore fluids is approximately constant $(\sim 490 \mathrm{mM})$, but shows some decrease on approach to the lower basalt (Fig. 21).

$\mathrm{The} \mathrm{Na} / \mathrm{Cl}$ ratio of the pore fluids appears to increase in lithologic Unit III, but shows a marked minimum in the vicinity of the upper basalt. On approach to the basalt sampled from the bottom of the hole, the $\mathrm{Na} / \mathrm{Cl}$ ratio increases.

Concentrations of $\mathrm{Li}$ are similar to seawater $(27 \mu \mathrm{M})$ in the nearsurface sediments (0-25 mbsf), then increase sharply to $>3500 \mu \mathrm{M}$ in the sandy interval between 103.7 and $141.7 \mathrm{mbsf}$ (lithologic Unit III). There is a small reduction in the Li content of the pore fluids immediately below the upper basalt at $\sim 161 \mathrm{mbsf}$, although Li returns to a concentration similar to that recorded in lithologic Unit III at 190 mbsf. Below 190 mbsf, concentrations of Li fall sharply to $<600 \mu \mathrm{M}$. There is an increase in Li toward the lower basalt (which is located at 402 mbsf; Fig. 21). immediately below the upper basalt. Concentrations of $\mathrm{K}$ also appear to increase in the sandy interval (lithologic Unit III). In the upper 40 $\mathrm{m}$ of the sediment column, $\mathrm{K}$ is similar to seawater $(\sim 10 \mathrm{mM})$, but decreases to $\sim 5 \mathrm{mM}$ before increasing on approach to lithologic Unit III. Below the basalt, $\mathrm{K}$ decreases and is approximately constant $(\sim 5$ $\mathrm{mM}$ ) below $280 \mathrm{mbsf}$.

\section{Alkali Earth Elements}

Concentrations of $\mathrm{Mg}$ fall steadily from seawater values (54 mM) at the sediment/seawater interface to $\sim 3 \mathrm{mM}$ in lithologic Unit III (75 $-104 \mathrm{mbsf}$ ). There is a small increase in $\mathrm{Mg}$ in the sample adjacent to the upper basalt; this may be related to contamination of this sample with seawater, based on the $\mathrm{SO}_{4}$ concentration. There is little variation in the $\mathrm{Mg}$ content of the pore fluids between the basalt and $\sim 250$ mbsf. Below $250 \mathrm{mbsf}$ there is a small, broad increase in concentrations of $\mathrm{Mg}$ (with concentrations increasing from $\sim 8$ to $12 \mathrm{mM}$ ). On approach to the basalt at the base of the hole, $\mathrm{Mg}$ decreases to $\sim 4 \mathrm{mM}$.

In the upper $20 \mathrm{~m}$ of sediment, concentrations of $\mathrm{Ca}$ are similar to seawater $(\sim 10 \mathrm{mM})$, but then increase sharply between 20 and 65 mbsf. Ca decreases in lithologic Unit III, and then increases sharply immediately below the upper basalt. Below $200 \mathrm{mbsf}$, concentrations of Ca increase slowly with depth until $\sim 380$ mbsf. Below 380 mbsf, toward the lower basalt, there is a small reduction in the $\mathrm{Ca}$ content of the pore fluids.

Similarly to $\mathrm{Ca}$, concentrations of $\mathrm{Sr}$ increase from $\sim 87 \mu \mathrm{M}$ at the seawater/sediment interface to $\sim 300 \mu \mathrm{M}$ at $65 \mathrm{mbsf}$, then fall in lithologic Unit III. Below this unit, the Sr concentrations increase to a peak at $\sim 210$ mbsf and are apparently unaffected by the upper basalt. Below 280 mbsf, concentrations of Sr are fairly constant (250-350 $\mu \mathrm{M})$.

\section{Chloride}

The $\mathrm{Cl}$ concentration depth profile is dominated by two features. First, there is a sharp decline from seawater values $(556 \mathrm{mM})$ toward lithologic Unit III to $<480 \mathrm{mM}$ in this unit. Second, concentrations of $\mathrm{Cl}$ increase to $\sim 700 \mathrm{mM}$ in the samples immediately adjacent to the 

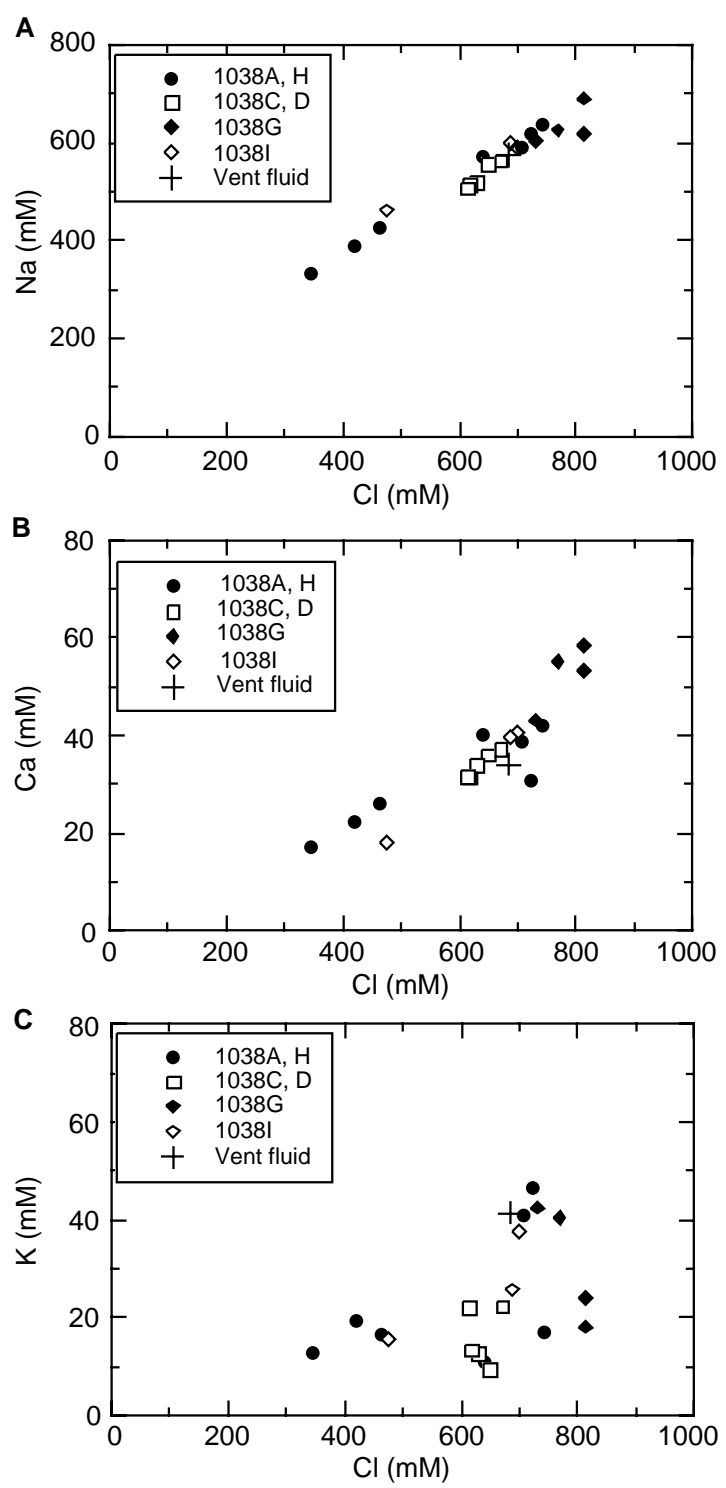

Figure 20. Composition of a hydrothermal component in Site 1038. Data of pore fluids with depleted $\mathrm{Mg}$ and $\mathrm{SO}_{4}$ concentrations $\left(\mathrm{Mg}<5.4 \mathrm{mM}\right.$ and $\mathrm{SO}_{4}$ $<2.8 \mathrm{mM}$ ) and the end-member composition of vent fluid (from Campbell et al., 1994) are plotted. A. Na vs. Cl concentration. B. Ca vs. Cl. C. K vs. Cl.

upper basalt ( $\sim 160 \mathrm{mbsf})$. Below the basalt, $\mathrm{Cl}$ increases slightly with depth to $\sim 380 \mathrm{mbsf}$ (recording a maximum concentration of $564 \mathrm{mM}$ ) before falling slightly to values less than seawater on approach to the basalt at the base of the hole.

\section{Nutrient Elements}

In this section, we consider $\mathrm{SO}_{4}, \mathrm{NH}_{4}$, and alkalinity $\left(\mathrm{HCO}_{3}\right)$. Concentrations of $\mathrm{SO}_{4}$ are reduced to zero within the upper $10 \mathrm{~m}$ of the sediment column. Those samples showing a non-zero $\mathrm{SO}_{4}$ concentration below this depth are considered to show a small contamination with seawater.

Concentrations of $\mathrm{NH}_{4}$ increase subsurface, showing a small peak at $\sim 60$ mbsf. There is a marked increase in $\mathrm{NH}_{4}$ in lithologic Unit III, and a further increase in $\mathrm{NH}_{4}$ near the upper basalt. Below $200 \mathrm{mbsf}$, concentrations of $\mathrm{NH}_{4}$ fall and are approximately constant $(\sim 3 \mathrm{mM})$ below 220 mbsf.

Alkalinity increases sharply below the seawater/sediment interface, attaining a peak at $\sim 30$ mbsf. The volume of pore fluid obtained from samples from the sandy interval or near the upper basalt were insufficient to allow alkalinity measurements. Below the basalt, there is little of note in the concentration depth profile, although alkalinity values remain remarkably high.

\section{Silica and Boron}

Because of problems inherent with $\mathrm{Si}$ analysis of squeezed pore fluids, that are mostly caused by differences in temperature at which the squaring occurs and actual in situ temperatures (see "Inorganic Geochemistry" section, "Middle Valley: Bent Hill Area" chapter), the concentration depth profile is not discussed in detail; it is sufficient to point out a fall in Si concentrations in samples collected immediately below the upper basalt section.

Concentrations of B increase with depth below the seawater/sediment interface; there is a marked increase in the gradient of this increase in lithologic Unit III, where a maximum B concentration of $\sim 9$ $\mathrm{mM}$ is recorded. Adjacent to the upper basalt section, the B content of the pore fluids decreases. Below $200 \mathrm{mbsf}$, concentrations of B are fairly constant $(4-5 \mathrm{mM})$. There is a small increase $(4-6 \mathrm{mM})$ in the pore fluid B content below $350 \mathrm{mbsf}$ toward the basalt at the base of the hole.

\section{Discussion}

In this section, we first discuss the prominent features of the porefluid chemistry of Hole 1038I, then contrast the concentration depth profiles from this site with those from the Escanaba Reference Site (Hole 1037B).

\section{Hydrothermal Alteration}

The thermal gradient of Hole 1038I, based on measurements in the upper $60 \mathrm{~m}$, is $\sim 2^{\circ} \mathrm{C} / \mathrm{m}$. Pore-fluid compositions are consistent with elevated temperature; concentrations of $\mathrm{Li}$ and $\mathrm{B}$ below 300 mbsf are far higher $(\sim 500 \mu \mathrm{M}$ and $\sim 6 \mathrm{mM}$, respectively) than those recorded in Hole 1037B $(\sim 100 \mu \mathrm{M}$ and $0.8 \mathrm{mM}$, respectively). Both of these elements are readily mobilized from sediments at temperatures greater than $\sim 50^{\circ} \mathrm{C}$ (e.g., Chan et al., 1994; Spivack and Edmond, 1987). Furthermore, the concentration of $\mathrm{Mg}$ in the pore fluids in this hole declines far more rapidly with increasing depth than observed at Hole 1037B, supporting hydrothermal alteration of the sediments at Hole 1038I.

\section{Pore-Fluid Chemistry in the Sandy Interval (Unit III)}

There is a marked change in the composition of the pore fluids in the sandy interval between 75 and 103 mbsf. Concentrations of $\mathrm{Ca}$, $\mathrm{Cl}, \mathrm{Mg}$, and $\mathrm{Sr}$, and the $\mathrm{Na} / \mathrm{Cl}$ ratio, all decrease, whereas concentrations of $\mathrm{Li}, \mathrm{B}, \mathrm{K}$, and $\mathrm{NH}_{4}$ all increase. This is consistent with lateral flow of a hydrothermal component with low $\mathrm{Cl}$ through the sandy interval. During transport, this hydrothermal component appears to have acquired $\mathrm{Li}, \mathrm{B}, \mathrm{K}$, and $\mathrm{NH}_{4}$ from the sediments. Fluids with a similar composition have also been sampled at Holes 1038A and $1038 \mathrm{H}$. Phase separation is the most likely physical process that can explain the low $\mathrm{Cl}$ content of the pore fluids in this sandy interval. Further analysis of the $\mathrm{Li}$ and $\mathrm{Sr}$ isotopes, as well as $\delta \mathrm{D}$ and $\delta^{18} \mathrm{O}$ compositions of these pore fluids will help confirm the source of the fluids within the sandy interval.

\section{Pore-Fluid Chemistry in the Vicinity of the Upper Basalt}

Approximately $15 \mathrm{~cm}$ of basalt was recovered in Section 1691038I-18X-CC ( 161 mbsf); a large proportion of the basalt recovered was chilled margin, suggesting that this unit is fairly thin. There is a drastic change in the pore-water concentrations immediately adjacent to the basalt; concentrations of $\mathrm{Cl}, \mathrm{Ca}, \mathrm{K}, \mathrm{Na}, \mathrm{Mg}$, and $\mathrm{NH}_{4}$ all increase, whereas concentrations of $\mathrm{HSiO}_{4}, \mathrm{Li}$, and $\mathrm{B}$ show a small reduction. Two scenarios may be envisaged to account for this change in the pore-fluid chemistry. First, the changes could result from the direct interaction between the pore fluids and the basalt, possibly at elevated temperature if the basalt is a sill. Hydration of the 

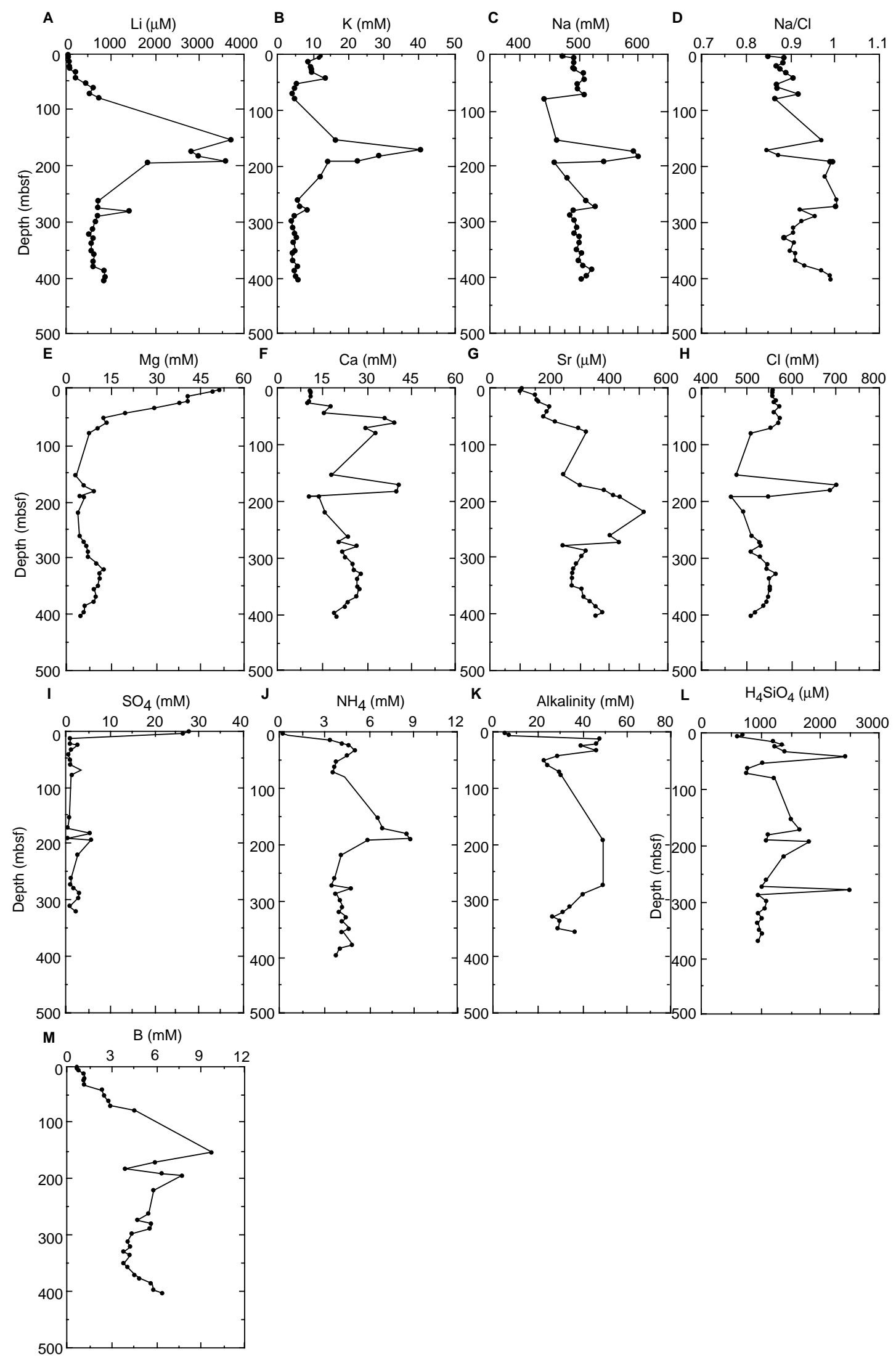

Figure 21. Concentration depth profiles at Hole $1038 \mathrm{I}$ of A. L. B. K. C. Na. D. Na/C. E. Mg. F. Ca. G. S. H. C. I. SO S. J. NH $_{4}$ K. alkalinity. L. $\mathrm{H}_{4} \mathrm{SiO}_{4}$. M. B. 
basalt as a result of alteration may not, however, be sufficient to support the observed increase in the $\mathrm{Cl}$ content of the pore fluids. Furthermore, in contrast to the pore-fluid chemistry, leaching of $\mathrm{K}$ from basalt is usually accompanied by the leaching of $\mathrm{Li}$ and $\mathrm{B}$. The second possibility is that the basalt acts as a high permeability conduit (aquifer) for lateral advection of a high $\mathrm{Cl}$ fluid, or traps a high $\mathrm{Cl}$ fluid below it (aquiclude). It is possible that this fluid is the high $\mathrm{Cl}$ hydrothermal conjugate of the low $\mathrm{Cl}$ fluid observed in the sand layer. The lack of a sedimentary signature to the $\mathrm{Li}$ and $\mathrm{B}$ content of the pore fluids is consistent with the focusing of this fluid through a zone of high permeability (and not passing through the sediments).

\section{Pore-Fluid Geochemistry Below 300 mbsf}

Although changes in the concentration depth profiles of the pore fluids are less dramatic below 300 mbsf than in the vicinity of the sandy interval and upper basalt, there are several interesting features (Fig. 22). On approach to the basalt at the base of the hole, concentrations of $\mathrm{Ca}, \mathrm{Mg}, \mathrm{Cl}$, and $\mathrm{Na}$ fall, and $\mathrm{Li}$ and $\mathrm{B}$ concentrations increase along with the $\mathrm{Na} / \mathrm{Cl}$ ratio of the pore fluids. These changes are not consistent with the direct interaction of pore fluids with the basalt; rather they suggest that the recovered basalt is from a thin sill or flow, and that low $\mathrm{Cl}$ fluids may be trapped below it.

\section{Comparison with Hole 1037B}

One of the most outstanding features in the concentration depth profiles of pore fluids from the Reference Site (Hole 1037B) is a correlation with a change in the major provenance of sediments supplied to the Escanaba Trough (see "Inorganic Geochemistry" section, "Middle Valley: Bent Hill" chapter). This correlation is not apparent at Hole 1038I; thermally enhanced alteration of the sediments has clearly overprinted any primary sedimentary signature to the porefluid chemistry. Furthermore, other features in the pore-water profiles at Site 1037B (such as the distinct maxima in the Li profile at 320 and $470 \mathrm{mbsf}$ ) are not apparent at Hole 1038I; pervasive hydrothermal alteration of the sediments means that stratigraphic correlation of the pore-fluid chemistry between this hole and the reference hole is impossible.

\section{Summary Discussion}

\section{Distribution of a Hydrothermal Component in Holes Near Sulfide Outcrops}

A hydrothermal component was obvious in the pore fluids in all of the holes in the hydrothermal area. It dominates pore-fluid compositions just below the surface in Holes 1038C and 1038D, below 40 mbsf in Hole 1038A, and below 40 mbsf in Holes 1038F and 1038G. Also in Hole 1038B, a hydrothermal component above $20 \mathrm{mbsf}$ is suggested by the nature of the concentration depth gradients below this depth. Entrained seawater is observed only at very shallow depths except for the deeper layer ( $>40 \mathrm{mbsf}$ ) in Hole 1038B, which indicates a seawater mixing signature. In Hole 1038I, located in the center part of Central Hill, a low salinity hydrothermal component is evident in the sandy interval (Unit III) at 75.9-103.1 mbsf and a high salinity component beneath the basalt at $\sim 160$ mbsf. This distribution pattern of hydrothermal signatures implies that a hydrothermal fluid ascends along structural boundaries of the uplifted hill and the flows laterally through permeable horizons.

\section{Chemical Composition of the Hydrothermal Component}

Hydrothermal fluids venting from the seafloor were collected from this area during the Alvin dive studies in 1988, and their chemical compositions were studied (Campbell et al., 1994; Böhlke et al., 1994). These results showed a single high-salinity hydrothermal fluid end-member for both the $217^{\circ} \mathrm{C}$ vent fluid (near Holes $1038 \mathrm{~A}$, $1038 \mathrm{E}$, and $1038 \mathrm{H}$ ) and the $108^{\circ} \mathrm{C}$ vent fluid (near Hole 1038B). On the other hand, pore fluids collected during the drilling show a wide range in chemical composition. To investigate the source of a hydrothermal component, the data from pore fluids with depleted $\mathrm{Mg}$ and $\mathrm{SO}_{4}$ concentrations are plotted in Figure 20.

Concentrations of $\mathrm{Na}$ and $\mathrm{Ca}$ show a good relationship with the $\mathrm{Cl}$ concentration of the fluids. Moreover, the hydrothermal vent fluid composition plots on the same trend. This suggests that the pore fluids and the hydrothermal vent fluid originate from a single source and that high-salinity and low-salinity end-members were produced by phase separation in the hydrothermal system.

On the other hand, the K concentration does not show a consistent linear relationship with the $\mathrm{Cl}$ concentration. Although most of the pore fluids from $1038 \mathrm{H}$ show a linear trend that passes through the composition of the vent fluid, other pore-fluid samples fall below this line, suggesting $\mathrm{K}$ uptake in the sediment.

\section{Conclusions}

Pore-water fluids collected from the sulfide area of Site 1038 show a wide range in chemical compositions. The $\mathrm{Cl}$ concentrations range from $300 \mathrm{mM}$ to $800 \mathrm{mM}$, indicating contributions of a hydrothermal fluid that experienced phase separation at depth. The linear relationship between $\mathrm{Na}$ and $\mathrm{Ca}$ concentrations with $\mathrm{Cl}$ concentration among the pore fluids suggests they originate from a single source, and the phase separation induces a wide range in chemical compositions. In most of the holes in the hydrothermal areas, a high-salinity hydrothermal component dominates pore fluids. A low salinity hydrothermal component is evident in the sand-rich layer in Holes $1038 \mathrm{~A}, 1038 \mathrm{H}$, and 1038I, suggesting a segregation of the vapor phase into the sand layer. The presence of hydrothermal fluids that have undergone phase separation at shallow depths below the sulfide mineralization would require that hydrothermal fluid circulation has occurred very recently, or that those extreme chemical concentration gradients are maintained by active fluid flow in the shallow subsurface.

\section{ORGANIC GEOCHEMISTRY}

Shipboard gas analyses were carried out on headspace and expansion void samples from sediments of Site 1038. Solvent extracts of bitumen from sediments were analyzed for fluorescence and by gas chromatography (GC) to assess the occurrence of hydrothermal petroleum and its maturity, and to characterize the sources of the organic matter. Routine elemental analyses were performed on sediments for total $\mathrm{C}, \mathrm{N}$, and $\mathrm{S}$, and carbonate carbon. Instrumentation, operating conditions, and procedures are summarized in the "Explanatory Notes" chapter (this volume).

\section{Volatile Gases}

The headspace gas compositions monitored for downcore sediment samples from Site 1038 are given in Table 9. The methane concentrations vary from 24 to $107,000 \mathrm{ppm}$, with significant amounts of higher molecular weight hydrocarbons $\left(\mathrm{C}_{2}-\mathrm{C}_{7}\right.$, including benzene and toluene; Fig. 23) and carbon dioxide. The highest hydrocarbon gas concentrations are found in Holes $1038 \mathrm{E}$ and $1038 \mathrm{H}$ on the northwestern flank of Central Hill, in Holes $1038 \mathrm{~F}$ and $1038 \mathrm{G}$ on the southeastern flank, and in Hole 1038I in the central area of the hill (Figs. 24-26). A biogenic methane zone is evident only in Hole 1038 I a depth interval of $10-40$ mbsf. Hole 1038 I was the only hole not drilled on or adjacent to a hydrothermal deposit (Fig. 1). The interpretation of a biogenic origin for methane is based on the high $\mathrm{CH}_{4}$ concentration and the high $\mathrm{C}_{1} / \mathrm{C}_{2}$ ratio (Fig. 26A, D). $\mathrm{C}_{1} / \mathrm{C}_{2}$ ratios for biogenic $\mathrm{CH}_{4}$ are generally taken as $>1000$ (Bernard et al., 1976). The other high methane peaks in the shallow sections of Holes 1038F, 
Figure 22. Concentration depth profiles below 300 mbsf at Hole 1038I. A. L. B. Na. C. Na/C. D. Mg. E. Ca. and $\mathbf{F}$. B. Note the change in scale between this figure and Figure 21.

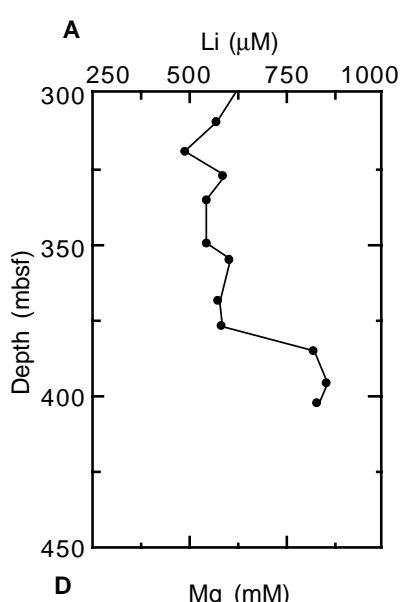

B
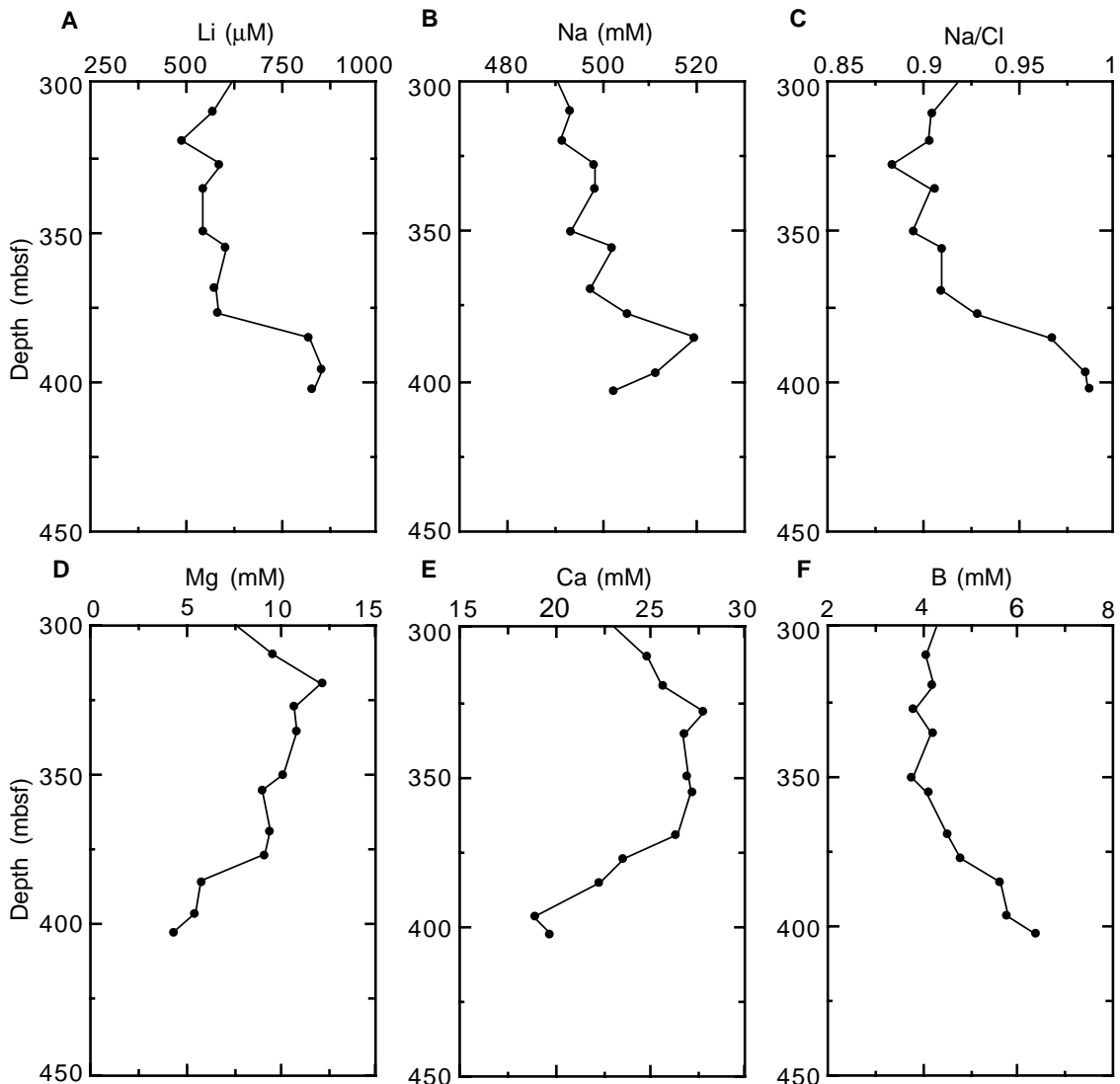

$1038 \mathrm{G}$, and $1038 \mathrm{H}$ are thermogenic, as the $\mathrm{C}_{1} / \mathrm{C}_{2}$ ratios are all $<100$. The low $\mathrm{C}_{1} / \mathrm{C}_{2}$ ratios (Table 9; Fig. 24C) are consistent with thermogenic $\mathrm{CH}_{4}$ generation caused by high heat flow (Bernard et al., 1976). The $C_{1} / C_{2}$ values $<30$ are interpreted as an indication of the extremely high-temperature cracking of organic matter, as was also observed in Middle Valley in Hole 858C (Shipboard Scientific Party, 1992) and estimated here to be in the range of $200^{\circ}-300^{\circ} \mathrm{C}$ over brief geological time. Thermogenic methane generation in conventional basins typically occurs over millions of years in a temperature range of $120^{\circ}-160^{\circ} \mathrm{C}$ (Tissot and Welte, 1984). The methane profile in Hole 1038I from 250 to $400 \mathrm{mbsf}$ also shows high $\mathrm{C}_{1} / \mathrm{C}_{2}$ values $(>100)$ that are normally indicative of a biogenic origin. However, the presence of monoaromatic hydrocarbons (e.g., benzene) in the same interval supports a thermogenic and not biogenic origin. The hydrocarbon composition of gas voids sampled by vacutainers is almost pure methane (Table 9) because of its faster effusion from the indurated sediments than ethane and higher hydrocarbons. The vacutainer data are not plotted in the depth profiles.

Benzene and toluene are also present at high concentrations as given in Table 9 and shown in some examples for benzene in Figures 24-26. The concentrations of benzene and toluene are calculated using the same GC response factor as for the $n$-alkanes. The benzene concentration in some samples exceeds that of ethane, thus the ratio of $\mathrm{C}_{2}$ /benzene has been added to Table 9 and some of the depth profiles. Benzene and toluene represent products from the high-temperature cracking of organic matter (e.g., Simoneit et al., 1988; Hunt, 1996; McCollom et al., 1997), and, thus, confirm the high temperatures of these sedimentary environments. These compounds were not found in the sediments of the Middle Valley hydrothermal system. Benzene and toluene are relatively concentrated in the zones of thermogenic gas (Figs. 25-27; Table 9) and occur with the other gasoline range hydrocarbons, giving the gas the characteristic petroleum off- gas odor (Simoneit et al., 1988; Hunt, 1996). It also should be pointed out that these sediments have relatively low contents of gas and volatiles (mainly $\mathrm{CH}_{4}$ ) because of the dominant terrigenous composition of the sedimentary organic matter composed of wax $n$-alkanes with $\mathrm{C}_{\max }$ at $\mathrm{C}_{29}$ or $\mathrm{C}_{31}$, wood fragments and pollen from terrestrial plants (Simoneit et al., 1988; Kvenvolden and Simoneit, 1990; Kvenvolden et al., 1994). The terrigenous organic matter provenance for Escanaba Trough has been described for Reference Site 1037.

Carbon dioxide occurs at high concentrations in Holes 1038D1038I (Table 9). For example, $\mathrm{CO}_{2}$ decreases with depth from 84,000 ppm to background in Holes $1038 \mathrm{~F}$ and $1038 \mathrm{G}$ (Fig. 24D). $\mathrm{CO}_{2}$ is also high throughout Hole 1038I, with a maximum at $200 \mathrm{mbsf}$. A steep increase occurs at depth (Fig. 26E), and a maximum occurs at mid depth in Hole $1038 \mathrm{H}$ (Fig. 25E). $\mathrm{H}_{2} \mathrm{~S}$ was not detectable by GC, although its odor was often noted.

\section{Bitumen Fluorescence}

Extracts from sediments of Site 1038 were colorless except in the sections with hydrothermal petroleum. The extract yields were high in the hydrothermal petroleum zones, and the bitumens had a strong yellow-white fluorescence. The high extract yields and intense fluorescence in the upper sections of Holes 1038B, 1038C, 1038F, and $1038 \mathrm{G}$ indicate full maturity and migration from depth or lateral horizons to the shallower zones where the hydrothermal petroleum accumulated. This strong yellow-white fluorescence is a diagnostic indicator of thermal maturity, which is interpreted in these holes as a high temperature alteration of organic matter occurring over a range of $150^{\circ}-250^{\circ} \mathrm{C}$ during an unknown but brief period of time. These extracts were analyzed by high-resolution GC for further interpretation. Fluorescence or petroleum horizons were not detectable in Holes $1038 \mathrm{H}$ and $1038 \mathrm{I}$. 
Table 9. Composition of gas in headspace or void samples derived from sediments, Site 1038.

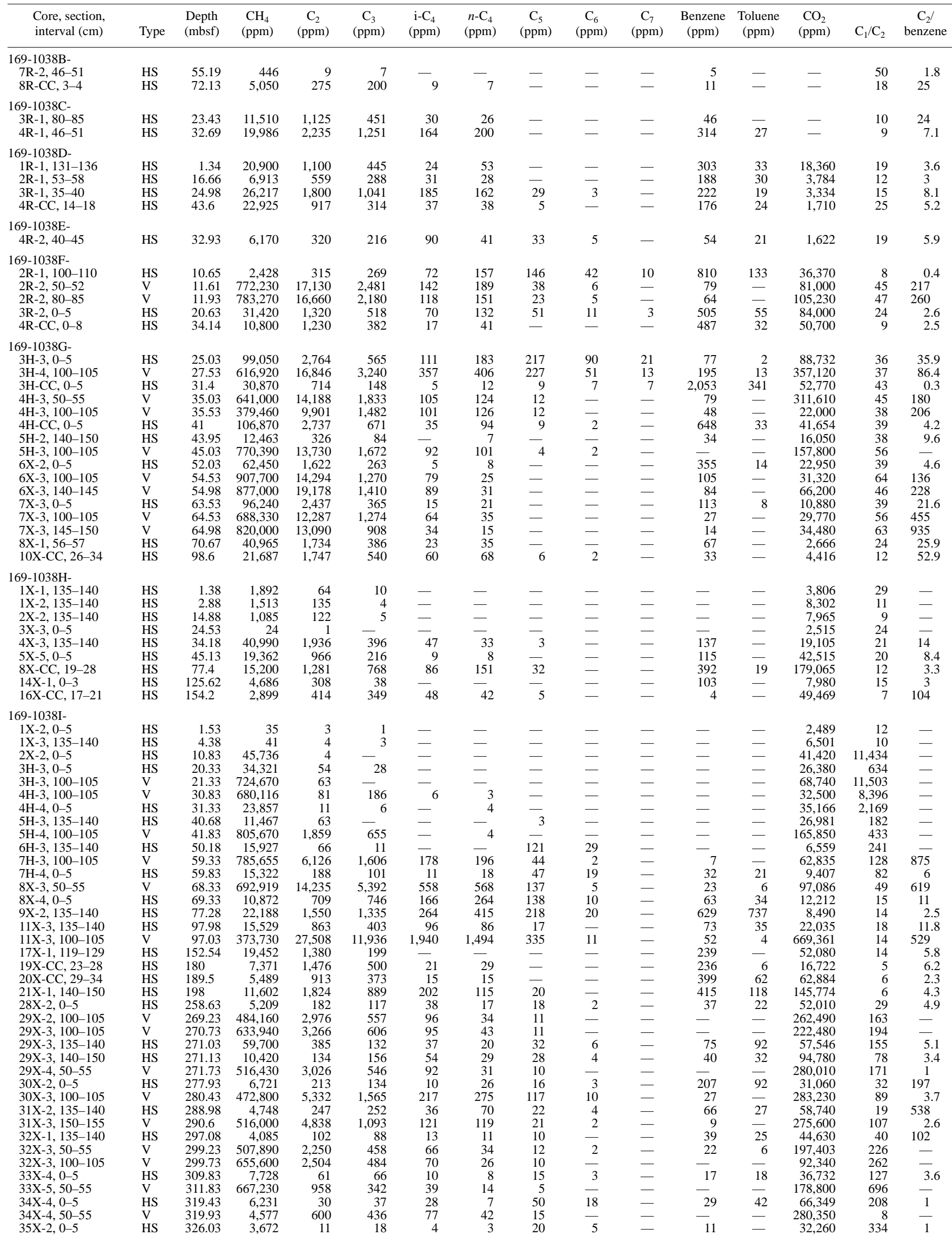


Table 9 (continued).

\begin{tabular}{|c|c|c|c|c|c|c|c|c|c|c|c|c|c|c|c|}
\hline $\begin{array}{l}\text { Core, section, } \\
\text { interval }(\mathrm{cm})\end{array}$ & Type & $\begin{array}{l}\text { Depth } \\
\text { (mbsf) }\end{array}$ & $\begin{array}{c}\mathrm{CH}_{4} \\
(\mathrm{ppm})\end{array}$ & $\begin{array}{c}\mathrm{C}_{2} \\
(\mathrm{ppm})\end{array}$ & $\begin{array}{c}\mathrm{C}_{3} \\
(\mathrm{ppm})\end{array}$ & $\begin{array}{c}\mathrm{i}-\mathrm{C}_{4} \\
(\mathrm{ppm})\end{array}$ & $\begin{array}{c}n-\mathrm{C}_{4} \\
(\mathrm{ppm})\end{array}$ & $\begin{array}{c}\mathrm{C}_{5} \\
(\mathrm{ppm})\end{array}$ & $\begin{array}{c}\mathrm{C}_{6} \\
(\mathrm{ppm})\end{array}$ & $\begin{array}{c}\mathrm{C}_{7} \\
(\mathrm{ppm})\end{array}$ & $\begin{array}{c}\text { Benzene } \\
(\mathrm{ppm})\end{array}$ & $\begin{array}{c}\text { Toluene } \\
\text { (ppm) }\end{array}$ & $\begin{array}{c}\mathrm{CO}_{2} \\
(\mathrm{ppm})\end{array}$ & $\mathrm{C}_{1} / \mathrm{C}_{2}$ & $\begin{array}{c}\mathrm{C}_{2} / \\
\text { benzene }\end{array}$ \\
\hline $35 \mathrm{X}-2,100-105$ & V & 327.03 & 804,700 & 461 & 402 & 80 & 28 & 22 & 2 & - & - & - & 248,660 & 1,746 & - \\
\hline $36 \mathrm{X}-1,135-140$ & HS & 335.48 & 4,928 & 25 & 30 & 9 & 7 & 58 & 27 & - & 26 & 45 & 53,000 & 197 & 1 \\
\hline $37 \mathrm{X}-3,0-5$ & HS & 346.73 & 3,730 & 13 & 47 & 9 & 7 & 40 & 11 & - & 34 & 63 & 33,400 & 287 & 0.4 \\
\hline $37 \mathrm{X}-4,100-105$ & V & 349.23 & 427,500 & 273 & 211 & 17 & 8 & 5 & - & - & - & - & 83,000 & 1,566 & - \\
\hline $38 \mathrm{X}-1,135-140$ & HS & 354.68 & 6,775 & 42 & 43 & 15 & 11 & 63 & 2 & 2 & 24 & 55 & 82,045 & 161 & 1.8 \\
\hline $38 \mathrm{X}-1,150-155$ & $\mathrm{~V}$ & 354.83 & 477,240 & 432 & 263 & 35 & 12 & 6 & - & - & - & - & 140,030 & 1,105 & - \\
\hline $39 X-3,0-5$ & HS & 365.93 & 8,233 & 63 & 92 & 29 & 22 & 65 & 8 & - & 63 & 94 & 75,950 & 131 & 1 \\
\hline $39 \mathrm{X}-4,100-105$ & $\mathrm{~V}$ & 368.43 & 814,550 & 911 & 277 & 40 & 16 & 6 & - & - & - & - & 231,630 & 894 & - \\
\hline $40 X-2,0-5$ & HS & 374.03 & 67,224 & 97 & 293 & 13 & 8 & 46 & 4 & - & 205 & 569 & 46,270 & 693 & 0.5 \\
\hline $40 \mathrm{X}-5,100-105$ & $\mathrm{~V}$ & 379.53 & 341,020 & - & 72 & 24 & 9 & 4 & - & - & - & - & 239,750 & - & - \\
\hline $41 X-2,0-5$ & HS & 383.63 & 8,668 & 69 & 68 & 34 & 14 & 69 & 4 & - & 22 & 55 & 68,000 & 126 & 3.1 \\
\hline $42 \mathrm{X}-3,135-140$ & HS & 396.18 & 5,200 & 137 & 191 & 121 & 62 & 105 & 11 & 3 & 40 & 68 & 78,250 & 38 & 3.4 \\
\hline $43 \mathrm{X}-1,90-100$ & HS & 402.35 & 5,354 & 336 & 432 & 233 & 171 & 228 & 34 & 8 & 54 & 66 & 120,740 & 16 & 6.2 \\
\hline
\end{tabular}

Notes: $\mathrm{HS}=$ headspace and $\mathrm{V}=$ vacutainer. $-=$ no data

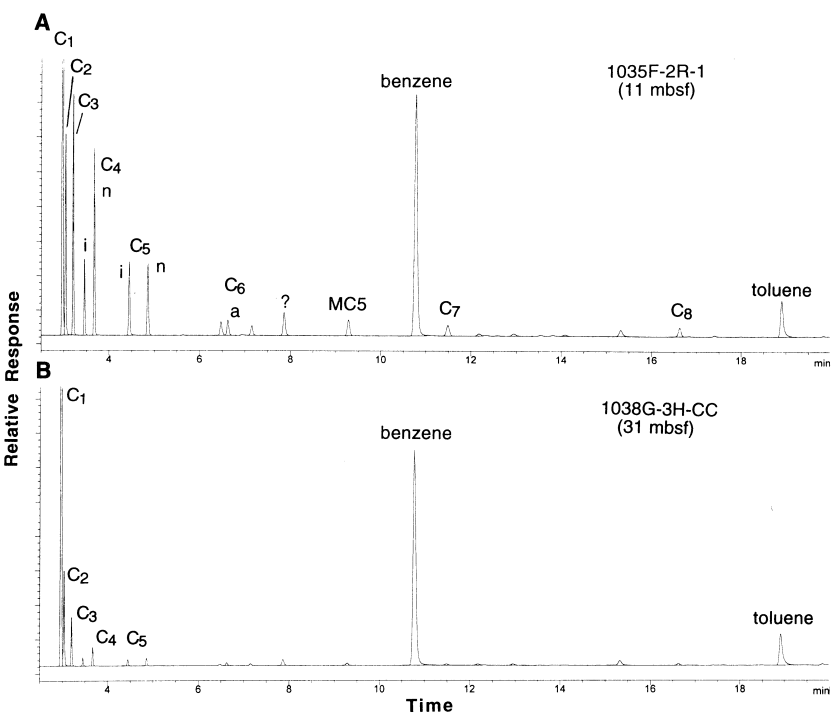

Figure 23. Gas chromatograms of the headspace gas hydrocarbons. A. Section 169-1038F-2R-1. B. Section 169-1038G-3H-CC. $C_{i}=$ carbon chain length of alkanes, $\mathrm{i}=$ iso, $\mathrm{a}=$ anteiso, $\mathrm{n}=$ normal, and MC5 $=$ methyl cyclopentane.

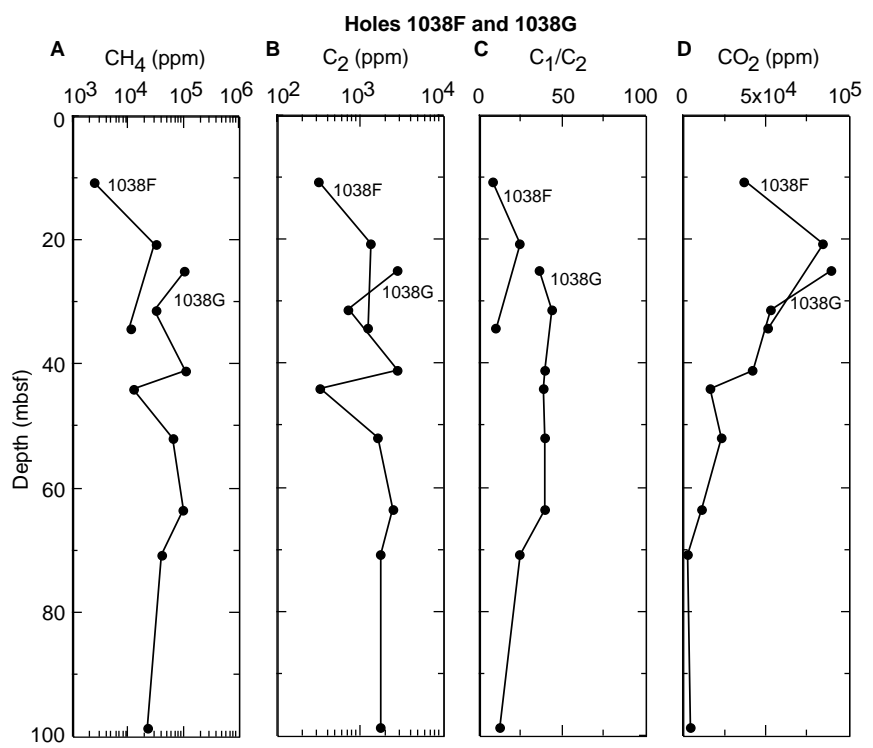

Figure 24. Depth profiles of the major gas components in samples from Holes $1038 \mathrm{~F}$ and 1038 G. A. methane. B. ethane. C. $\mathrm{C}_{1} / \mathrm{C}_{2}$ ratio. D. carbon dioxide.

\section{Black Soot}

Black soot (carbonaceous/mineral particulate matter) occurs in the deeper intervals of these holes, as was reported earlier for the hydrothermally altered sites in Middle Valley and the deeper sections of the reference hole. Black soot was present in the altered and lithified sediments at the following depths to the deepest sections recovered from these holes: Holes 1038A, 8.5 mbsf; 1038B, 34 mbsf; 1038C, 0.5 mbsf; 1038D, 1.4 mbsf; 1038E, 33 mbsf; 1038F, 11 mbsf; 1038G, 22 mbsf; 1038H, 0 mbsf; and 1038I, 105 mbsf. The black soot is interpreted to represent the kerogen carbon residue after in situ generation of the bitumen.

\section{Bitumen Analyses}

The supernatant (hexane) layers from the hexane/methanol extracts of the sediment samples prepared for fluorescence evaluation were concentrated and analyzed by high-resolution GC as described before. Typical GC traces are shown in Figure 28. The bitumen parameters for maturation and organic matter sources are listed in Table 10. Pristane (Pr) to $n-\mathrm{C}_{17}$ and phytane $(\mathrm{Ph})$ to $n-\mathrm{C}_{18}$ ratios are not given because of the low concentrations of these compounds in many samples, although $\mathrm{Pr} / \mathrm{Ph}$ is reported. Also, the $\mathrm{U}^{\mathrm{k}}{ }_{37}^{\prime}$ index (Shipboard Scientific Party, 1992; Simoneit et al., 1994) could not be determined for these samples because the $\mathrm{C}_{37}$ alkenones were not detectable.

Most of the organic matter in the sediments of Site 1038 is severely altered, having been converted to hydrothermal petroleum (Simoneit, 1985, 1990) in some of the holes, followed by migration into discrete horizons at shallow depths. Hydrothermal petroleum with an aromatic composition (i.e., enriched in polynuclear aromatic hydrocarbons [PAH]) occurs in Holes 1038B, 1038C, and 1038E (traces), and aliphatic hydrothermal petroleum is found in Holes $1038 \mathrm{G}$ and $1038 \mathrm{H}$ (traces). Examples of GC traces of aromatic hydrothermal petroleum are shown in Figures 28A and 28B, where the major resolved peaks are PAH. These oils are solid in situ, and based on their composition, are interpreted to represent the seared bitumen residue after extensive flushing with high-temperature fluids $\left(250^{\circ}-\right.$ $350^{\circ} \mathrm{C}$; Simoneit, 1984; Kawka and Simoneit, 1990; Simoneit and Fetzer, 1996). They do not have the same overall compositions as the hydrothermal petroleums analyzed previously from seabed dredge and core samples in Escanaba Trough, but have similar PAH contents to the previous samples (Kvenvolden et al., 1986; Kvenvolden and Simoneit, 1990). These previously analyzed petroleums were injected as veins into sulfide minerals of this hydrothermal system, which in turn, collapsed into talus and subsequently weathered leaving behind the petroleum tar. This was reported for a barite chimney from the Middle Valley hydrothermal system (Simoneit et al., 1992).

A mixture of PAH and aliphatic hydrocarbons comprises the hydrothermal petroleum in Hole $1038 \mathrm{~F}$, and a primarily aliphatic oil 

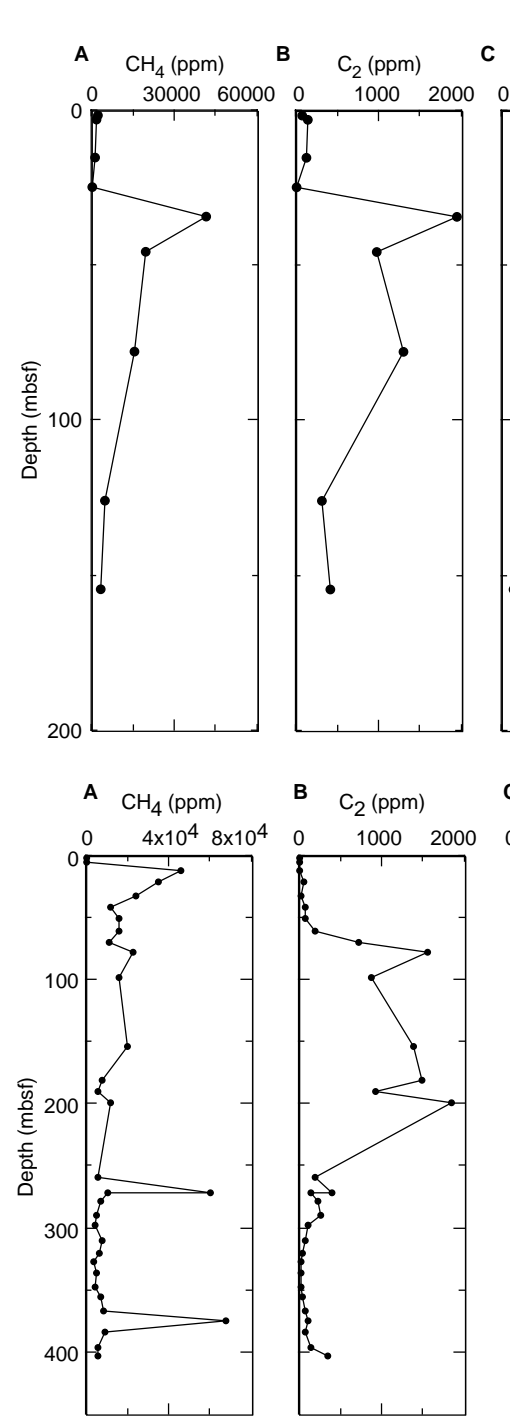

B

$\mathrm{C}_{2}(\mathrm{ppm})$

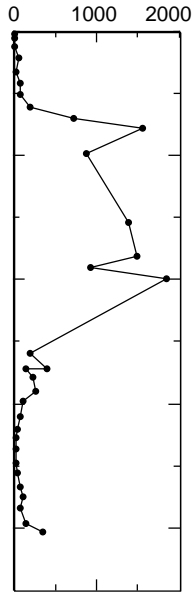

Cenzene (ppm)

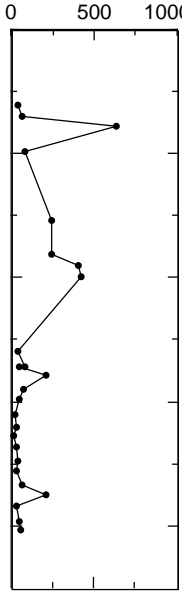

D

D $\mathrm{C}_{1} / \mathrm{C}_{2}$

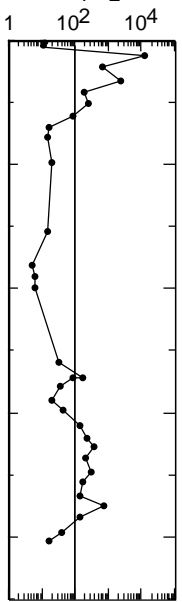

$1038 \mathrm{~F}$ and 1038

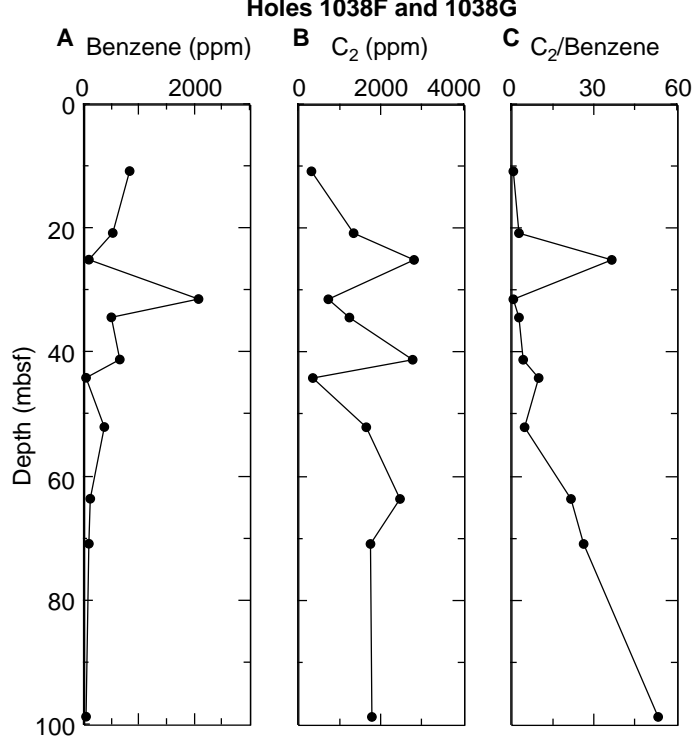

Figure 27. Depth profiles of (A) benzene, $(\mathbf{B})$ ethane, and $(\mathbf{C})$ the $\mathrm{C}_{2}$ /benzene ratio in samples from Holes $1038 \mathrm{~F}$ and $1038 \mathrm{G}$.
$\mathrm{CO}_{2}(\mathrm{ppm})$

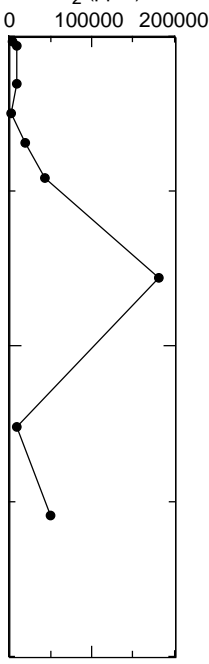

E $\mathrm{CO}_{2}(\mathrm{ppm})$

$0 \quad 1 \times 10^{5} \quad 2 \times 10^{5}$

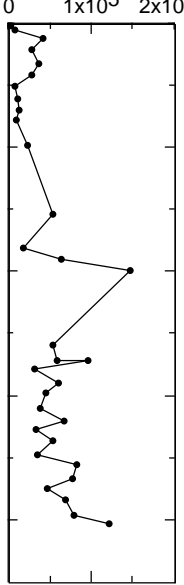

Figure 25. Depth profiles of the major gas components in samples from Hole 1038 H. A. methane. B. ethane. C. $\mathrm{C}_{1} / \mathrm{C}_{2}$ ratio. D. benzene. $\mathbf{E}$. carbon dioxide.
Figure 26. Depth profiles of the major gas components in samples from Hole 1038I. A. methane. B. ethane. C. benzene. D. $C_{1} / C_{2}$ ratio (note the log scale, vertical line marks $\left.C_{1} / C_{2}=100\right)$. E. carbon dioxide.

composition is found for the samples from Hole 1038G (Fig. 28C-E). The sample from Hole 1038F shows a slight odd to even carbon number preference $>\mathrm{C}_{22}$ (carbon preference index, $\mathrm{CPI}=1.8$ ), reflecting the terrigenous source of the organic matter from higher plants (wax signature; Simoneit, 1977, 1978). The hydrothermal petroleums from Hole $1038 \mathrm{G}$ are similar in composition as those reported previously (Kvenvolden et al., 1986, 1994). The intermediate catagenetic stage of organic matter alteration is evident in the example shown in Figure $28 \mathrm{~F}$, where the hydrocarbons have been cracked to the low molecular weight homologs and the unresolved complex mixture of branched and cyclic hydrocarbons, and where PAH compounds were superimposed. This is the precursor signature for the overmature petroleums found in Hole 1038B (cf. Fig. 28A, B).

Normal, although rapid, maturation of in situ bitumen as a function of depth is observed mainly in the upper sections of Holes 1038F and $1038 \mathrm{G}$ (to 20 and $30 \mathrm{mbsf}$, respectively) and to greater depth in Hole 1038I (to $160 \mathrm{mbsf}$ ). This is based on the CPI (range $\mathrm{C}_{24}-\mathrm{C}_{33}$ ) values that are near one at various, but shallow, depth intervals from these holes, as shown in Figure 29. The two examples of petroleums shown from Hole 1038G have a slight even to odd carbon number preference $>\mathrm{C}_{20}(\mathrm{CPI}<1.0)$ that was reported earlier for sediments from Escanaba Trough (Kvenvolden et al., 1994), Middle Valley ("Middle Valley: Bent Hill Area" and "Middle Valley: Dead Dog" chapters, this volume; Shipboard Scientific Party, 1992; Simoneit, 


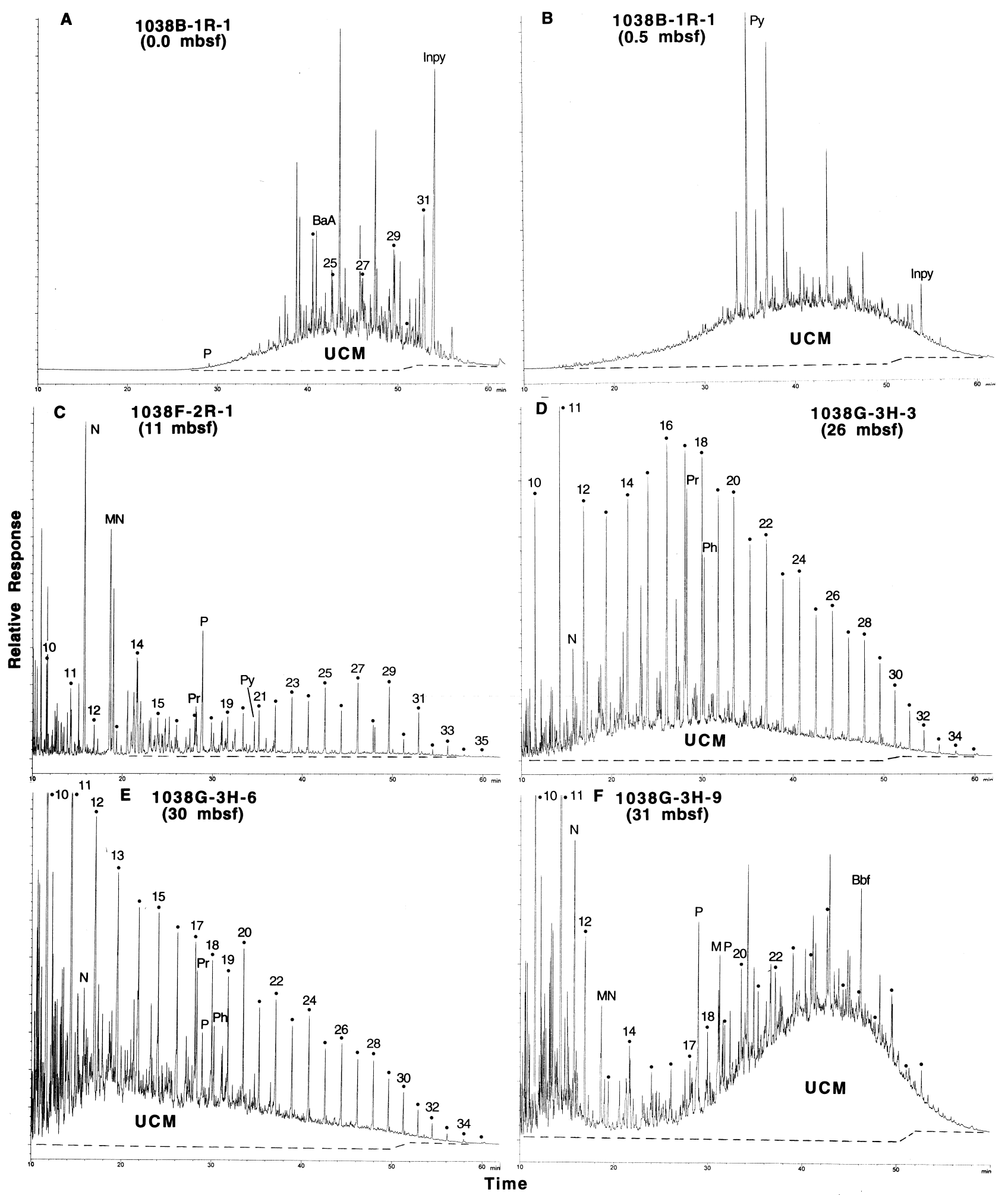

Figure 28. Typical gas chromatograms for total bitumen extracts from sediments of some holes from Site 1038. A. Sample 169-1038B-1R 1, 0 mbsf. B. Sample 1691038B-1R-1, 0.5 mbsf. C. Sample 169-1038F-2R-1, 11 mbsf. D. Sample 169-1038G-3H-3, oil; 26 mbsf. E. Sample 169-1038G-3H-6, 30 mbsf. F. Sample 1691038G-3H-9, 31 mbsf. $\mathrm{Pr}=$ pristane, $\mathrm{Ph}=$ phytane, $\mathrm{N}=$ naphthalane, $\mathrm{MN}=$ methylnaphthalene, $\mathrm{P}=$ phenanthrene, $\mathrm{MP}=$ methylphenanturene, $\mathrm{Py}=$ pyrene, Inpy = indenopyrene, and $\mathrm{BaA}=$ benz[a]anthracene. Dots and numbers refer to the chain length of homologous $n$-alkanes. 
Table 10. Various parameters for the solvent soluble organic matter in sediments, Site 1038.

\begin{tabular}{|c|c|c|c|c|c|}
\hline $\begin{array}{l}\text { Core, section, } \\
\text { interval }(\mathrm{cm})\end{array}$ & $\begin{array}{l}\text { Depth } \\
\text { (mbsf) }\end{array}$ & $\mathrm{C}_{\max }$ & $\mathrm{C}_{n}$ range & CPI & $\mathrm{Pr} / \mathrm{Ph}$ \\
\hline \multicolumn{6}{|l|}{ 169-1038A- } \\
\hline 2R-1, 3-4 & 8.53 & 27 & $15-35$ & 1.19 & 0.71 \\
\hline 8R-1, 10-11 & 66.71 & UCM & - & - & - \\
\hline 11R-CC, 3-4 & 104.8 & 25 & $10-35$ & 0.89 & 4.8 \\
\hline $12 \mathrm{R}-\mathrm{CC}, 3-4$ & 114.4 & 24 & $16-35$ & 0.84 & 1.2 \\
\hline \multicolumn{6}{|l|}{ 169-1038B- } \\
\hline 1R-1, 0-10 & 0.05 & Py & - & - & - \\
\hline 1R-1, 43-44 & 0.44 & Py & - & - & - \\
\hline $1 \mathrm{R}-1,51-52$ & 0.52 & Py & - & - & - \\
\hline 1R-1, 52-54 & 0.53 & Py & - & - & - \\
\hline $1 \mathrm{R}-1,117-120$ & 1.18 & Py & - & - & - \\
\hline 1R-CC, 3-5 & 6.8 & Py & - & - & - \\
\hline $5 \mathrm{R}-1,19-29$ & 34.14 & $\mathrm{~N}, \mathrm{P}, 25$ & $19-35$ & 0.84 & - \\
\hline \multicolumn{6}{|l|}{ 169-1038C- } \\
\hline $1 \mathrm{R}-1,30-31$ & 0.3 & Py & - & - & - \\
\hline $1 \mathrm{R}-1,50-65$ & 0.58 & Py & - & - & - \\
\hline 3R-1, 85-95 & 23.5 & $\mathrm{P}, \mathrm{N}$ & - & - & - \\
\hline $4 \mathrm{R}-1,51-61$ & 32.76 & $\mathrm{~N}, 28$ & $16-35$ & 0.96 & 0.67 \\
\hline \multicolumn{6}{|l|}{ 169-1038D- } \\
\hline 1R-1, 136-146 & 1.41 & $\mathrm{P}, 24$ & $15-35$ & 0.86 & 0.46 \\
\hline \multicolumn{6}{|l|}{ 169-1038E- } \\
\hline 2R-1, Piece 2 & 13.4 & $\mathrm{~A}, \mathrm{P}$ & - & - & - \\
\hline 2R-1, 100-101 & 14.35 & A, UCM & - & - & - \\
\hline 4R-2, 45-55 & 33 & $29, \operatorname{Pr}, \mathrm{N}$ & $10-35$ & 1.61 & 3.7 \\
\hline \multicolumn{6}{|l|}{ 169-1038F- } \\
\hline $2 \mathrm{R}-1,100-101$ & 10.65 & $\mathrm{~N}, \mathrm{P}, 27$ & $10-35$ & 1.79 & 2.4 \\
\hline $3 R-2,140-150$ & 22.05 & $\mathrm{~N}, \mathrm{P}, 11$ & $10-35$ & 0.9 & 1.4 \\
\hline 4R-CC, 3-4 & 38.3 & 16, Py & $10-35$ & 1.03 & 0.7 \\
\hline \multicolumn{6}{|l|}{ 169-1038G- } \\
\hline $3 \mathrm{H}-1,8-9$ & 22.08 & 11,27 & $10-35$ & 1.54 & 1.6 \\
\hline $3 \mathrm{H}-2,80-81$ & 24.31 & $\mathrm{P}, 20$ & $12-35$ & 1.52 & 2.5 \\
\hline $3 \mathrm{H}-2,142-150$ & 24.96 & $\mathrm{~N}, \mathrm{P}, 27$ & $10-35$ & 1.96 & 3.8 \\
\hline $3 \mathrm{H}-3,47-48$ & 25.48 & 11,16 & $10-35$ & 0.79 & 1.4 \\
\hline $3 \mathrm{H}-3,48-66$ & 25.57 & 11,17 & $10-35$ & 0.73 & 1.4 \\
\hline $3 \mathrm{H}-3,104-105$ & 26.05 & $\mathrm{~N}, \mathrm{P}, 23$ & $10-35$ & 1.59 & 3.7 \\
\hline $3 \mathrm{H}-4,95-96$ & 27.46 & 14,27 & $10-35$ & 1.47 & 1.2 \\
\hline $3 \mathrm{H}-5,140-150$ & 29.45 & $\mathrm{~N}, \mathrm{P}, 22$ & $10-35$ & 1.24 & 1.6 \\
\hline $3 \mathrm{H}-6,56-57$ & 30.06 & $\mathrm{P}, 22,27$ & $15-35$ & 1.37 & 1.1 \\
\hline $3 \mathrm{H}-6,59-60$ & 30.1 & 23 & $13-35$ & 1.09 & 1.2 \\
\hline $3 \mathrm{H}-6,105-106$ & 30.56 & 8,20 & $8-35$ & 0.72 & 1.7 \\
\hline $3 \mathrm{H}-6,136-137$ & 30.87 & 9,20 & $8-35$ & 0.77 & 1.6 \\
\hline $3 \mathrm{H}-6,140-141$ & 30.91 & 8,20 & $8-35$ & 0.75 & 1.7 \\
\hline $3 \mathrm{H}-7,7-8$ & 31.08 & 11,20 & $8-35$ & 0.77 & 1.8 \\
\hline $3 \mathrm{H}-8,54-55$ & 31.25 & $9, \mathrm{~N}$ & $8-33$ & - & - \\
\hline $3 \mathrm{H}-9,20-22$ & 31.31 & $11, \mathrm{~N}$ & $8-33$ & - & - \\
\hline $4 \mathrm{H}-1,54-55$ & 32.04 & $11, \mathrm{~N}$ & $8-33$ & - & - \\
\hline $4 \mathrm{H}-2,81-82$ & 33.82 & $11, \mathrm{P}$ & - & - & - \\
\hline $4 \mathrm{H}-5,38-46$ & 37.92 & $11, \mathrm{~N}$ & $8-21$ & - & 2 \\
\hline $5 \mathrm{H}-2,20-40$ & 42.8 & 22 & $19-35$ & 0.93 & - \\
\hline $7 \mathrm{X}-2,140-150$ & 63.45 & $11, \mathrm{Py}, 25$ & $10-35$ & 0.91 & 1.1 \\
\hline \multicolumn{6}{|l|}{ 169-1038H- } \\
\hline $1 X-1,3-4$ & 0.03 & Py, 22 & $16-35$ & 0.87 & 0.8 \\
\hline $1 \mathrm{X}-1,10-11$ & 0.11 & $\mathrm{BaA}, \mathrm{Py}, 26$ & $17-35$ & 0.93 & - \\
\hline $1 \mathrm{X}-1,140-150$ & 1.45 & 9,24 & $9-35$ & 0.83 & 0.8 \\
\hline $2 X-1,140-150$ & 13.35 & Py, 23 & $18-35$ & 0.94 & - \\
\hline $4 X-3,140-150$ & 34.25 & 26 & $16-35$ & 0.89 & - \\
\hline \multicolumn{6}{|l|}{ 169-1038I- } \\
\hline $1 X-1,140-150$ & 1.45 & $\operatorname{Pr}, 21$ & $14-33$ & 1.25 & 2.3 \\
\hline $1 X-3,140-150$ & 4.45 & 27 & $15-35$ & 3 & 2.3 \\
\hline $2 X-2,140-150$ & 12.25 & 29,27 & $15-35$ & 2.88 & 2 \\
\hline $3 \mathrm{H}-2,140-150$ & 20.25 & 27 & $11-35$ & 3.11 & 2.3 \\
\hline $4 \mathrm{H}-3,140-150$ & 31.25 & 29,27 & $10-35$ & 2.4 & 2.5 \\
\hline $5 \mathrm{H}-3,140-150$ & 40.75 & 27 & $16-35$ & 3.83 & 1.4 \\
\hline $9 \mathrm{X}-2,140-150$ & 77.35 & $\mathrm{~N}, \operatorname{Pr}, 29$ & $10-35$ & 2 & 6.1 \\
\hline $11 X-3,140-150$ & 98.05 & $\mathrm{~N}, 25$ & $8-28$ & 1.2 & 1.8 \\
\hline $17 X-1,119-129$ & 152.54 & $\mathrm{~N}, 22$ & $11-26$ & 1.02 & 1.1 \\
\hline
\end{tabular}

Notes: Major homologs are listed in decreasing order of concentration $\left(\mathrm{C}_{\mathrm{max}}\right) . \mathrm{Pr}=$ pristane, $\mathrm{Ph}=$ phytane, $\mathrm{N}=$ naphthalene, $\mathrm{A}=$ anthracene, $\mathrm{P}=$ phenanthrene, $\mathrm{Py}=$ pyrene, $\mathrm{BaA}=$ benz[a]anthracene, and $\mathrm{UCM}=$ unresolved complex mixture. Carbon preference index (CPI) calculated from $n-\mathrm{C}_{24}$ to $n-\mathrm{C}_{33}$.

1994), and for other geographic areas (e.g., Simoneit, 1977; Grimalt and Albaiges, 1987). It seems to be a characteristic of the source organic matter composition. Thermal maturation of petroleums generally does not produce CPI values $<1$, so that the low CPI for these holes is partially source related. The variability of the high CPI values

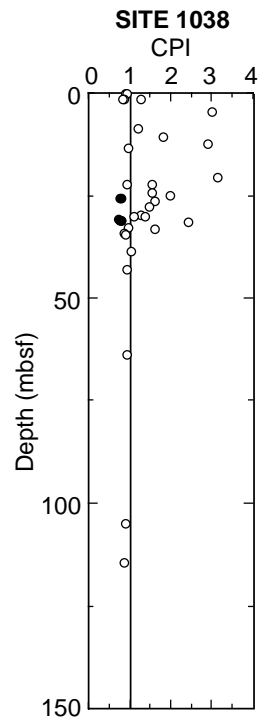

Figure 29. Scatter plot of CPI vs. depth for total bitumen extracts from sediment samples of Site 1038. Solid circles $=$ hydrothermal petroleum.

for bitumen in the shallower intervals reflects the different maturities of the source inputs and the admixture of terrigenous organic matter with minor marine organic matter (Table 10; Fig. 29). The isoprenoid alkane $(\mathrm{Pr} / \mathrm{Ph})$ ratios show considerable variations vs. depth for these holes (Table 10). This ratio is generally influenced by both source (e.g., Didyk et al., 1978) and maturation (e.g., Simoneit et al., 1981). The $\mathrm{Pr}$ to $\mathrm{Ph}$ ratio shows low values in most intervals of these cores, which is a reflection of full maturation. Also, many samples have high concentrations of naphthalenes (Fig. 28C) which, in combination with the volatile monocyclic aromatic compounds (e.g., benzene), result in the petroliferous odor of the gas and sediment samples.

Regional organic matter maturation around Central Hill is rapid for all holes. The organic matter in sediments from the northwest area is generally overmature in Holes $1038 \mathrm{~B}, 1038 \mathrm{E}$, and $1038 \mathrm{H}$ and has migrated with fluid flow to within $1 \mathrm{~m}$ of the seabed. Aromatic hydrothermal petroleum is present in the top 1-2 mbsf intervals of Holes 1038B and 1038H. Sediments from Hole $1038 \mathrm{C}$ in the northern area also contain aromatic hydrothermal petroleum in the upper 1 mbsf, and Hole 1038D has been stripped of bitumen. The organic matter in the sediments of Holes $1038 \mathrm{~F}$ and $1038 \mathrm{G}$ in the southeastern area has also undergone full maturation, but not at the extreme temperatures observed in the northern areas. The sedimentary organic matter of Hole $1038 \mathrm{~F}$ is fully mature and resides in situ within the upper 20 mbsf. In the case of Hole 1038G, it has completed maturation at $30 \mathrm{mbsf}$ and also remained in situ. However, there are two hydrothermal petroleum zones at 25-26 and 30-31 mbsf, where aliphatic/aromatic oils have been introduced laterally. Organic matter maturation with depth in Hole 1038I occurred in situ without migration and is complete at $\sim 160$ mbsf. This indicates high heat flow, but no extensive flow of hydrothermal fluid through the upper section of this hole. At depth, the bitumen has been stripped as a result of past high temperatures.

\section{Elemental Analyses}

The results of the total $\mathrm{C}, \mathrm{N}$, and $\mathrm{S}$ measurements for sediments from Site 1038 are given in Table 11, and depth profiles are shown in Figures 30-32. Total carbon and carbonate carbon range from $0.05 \%$ to $1.6 \%$ and from $0.04 \%$ to $1.25 \%$, respectively, throughout the holes drilled. The organic carbon determined by difference is not as reliable 
because of the significant analytical error at low values for the two methods. Organic carbon is low and ranges from $0 \%$ to $1.1 \%$. Minor trends of broad maxima are evident in TC and TIC for samples from Holes 1038F, 1038G, 1038H, and 1038I. A sharp decrease in TC and TOC from the seabed interval is observed for Holes $1038 \mathrm{H}$ and 1038I. The nitrogen content varies from $0 \%$ to $0.14 \%$, also showing a sharp drop from the maximum in the seabed interval for Hole 1038I and a general decrease for Holes $1038 \mathrm{~F}$ and $1038 \mathrm{G}$. The $\mathrm{C} / \mathrm{N}$ ratio was plotted for Hole 1038I to see if it showed maxima around the possible sill intrusion (161 mbsf) and above the basalt at the bottom of the hole. This is not the case, which indicates that the samples taken were not severely affected by heat from these basaltic rocks. Otherwise, depleted nitrogen and increased $\mathrm{C} / \mathrm{N}$ should have been observed. Sulfur is not detectable, except for low values near the seabed and a sulfide horizon in Hole 1038H (50-150 mbsf; Fig. 31D). This high sulfide zone appears to be fall-in from the top of the hole.

\section{Summary and Conclusions}

The organic matter content of the sediments from Site 1038 is low and heavily altered. The interstitial gas contents are high and composed mainly of methane and carbon dioxide with major amounts of ethane, benzene, and toluene. Biogenic methane is found only in Hole 1038I above 40 mbsf. Thermogenic hydrocarbons $\left(\mathrm{C}_{1}-\mathrm{C}_{8}\right)$ are found in all holes, and the presence of benzene and toluene support generation at very high temperatures. Carbon dioxide is high throughout Hole 1038I and in some of the other holes. Hydrogen sulfide occurs at trace levels in most of the holes at depth.

Hydrothermal petroleums occur in the shallow sections of several holes. They are products of severe organic matter alteration and have migrated into zones near the seafloor in Holes 1038B, 1038C, 1038E, $1038 \mathrm{G}$, and $1038 \mathrm{H}$. The full range of maturities (catagenesis to metagenesis) is observed with compositions varying from the aliphatic to the heavy aromatic (enriched in PAH) mixtures. The regional organic matter maturation around Central Hill has been rapid for all holes, and the temperatures were higher for this area than in the Middle Valley system. The sedimentary organic matter in the holes on hydrothermal mounds has been altered at depth, and migration has moved the products into shallower and cooler zones near the seafloor. The kerogen residue resides in situ as carbonized soot that is found at depth in all holes. The organic matter in sediments of Hole 1038I, located between the hydrothermal mounds, has been matured in situ without extensive fluid flushing to remove the bitumen products.

\section{MICROBIOLOGY}

Culture of high-temperature anaerobic microbes had been attempted during Leg 169, but no hyperthermophilic organisms were isolated from Sites 1035, 1036, or 1037. Central Hill, Escanaba Trough (Site 1038), was perhaps the most likely locale in which to find these microbes. Unlike the Bent Hill (Site 1035) and Dead Dog (Site 1036) areas, Central Hill has active sulfide structures with classic vent macrofauna (Grassle and Petrecca, 1994). Similar sulfide structures on the Juan de Fuca Ridge, Mid-Atlantic Ridge, and East Pacific Rise are host to a variety of microbes, including high-temperature anaerobic strains (Baross and Deming, 1995). High-temperature anaerobic culture enrichments were attempted from all holes except Holes 1038A and 1038F. Samples were taken from shallow (i.e., cooler) cores, where there was suspected hydrothermal upflow (Holes 1038C and 1038D) as well as from cores that exhibited chemistry more consistent with recharge (Holes 1038G and 1038I; see "Inorganic Geochemistry" section, this chapter). No growth was observed in any of the enrichments, indicating that common vent-associated microorganisms do not inhabit the sediments near these active sulfide mounds.
Table 11. Weight percentages for sediments, Site 1038.

\begin{tabular}{|c|c|c|c|c|c|c|}
\hline $\begin{array}{l}\text { Core, section, } \\
\text { interval }(\mathrm{cm})\end{array}$ & $\begin{array}{l}\text { Depth } \\
\text { (mbsf) }\end{array}$ & $\begin{array}{c}\mathrm{TC} \\
(\mathrm{wt} \%)\end{array}$ & $\begin{array}{c}\mathrm{TN} \\
(\mathrm{wt} \%)\end{array}$ & $\begin{array}{c}\text { T S } \\
\text { (wt } \%)\end{array}$ & $\begin{array}{c}\text { TIC } \\
(\mathrm{wt} \%)\end{array}$ & $\begin{array}{c}\text { TOC } \\
\text { (wt } \%)\end{array}$ \\
\hline \multicolumn{7}{|l|}{ 169-1038A- } \\
\hline 2R-CC, 3-4 & 18.04 & 0.25 & 0.01 & 0 & 0.05 & 0.2 \\
\hline $2 \mathrm{R}-\mathrm{CC}, 0-13$ & 18.13 & 0.28 & 0 & 0 & 0.05 & 0.23 \\
\hline $8 \mathrm{R}-1,10-11$ & 66.71 & 0.99 & 0.05 & 0 & 0.6 & 0.39 \\
\hline 11R-CC, 5-8 & 104.75 & 0.46 & 0.01 & 0 & 0.4 & 0.06 \\
\hline $12 \mathrm{R}-\mathrm{CC}, 0-3$ & 114.32 & 0.42 & 0 & 0 & 0.36 & 0.06 \\
\hline \multicolumn{7}{|l|}{ 169-1038B- } \\
\hline 3R-CC, 7-8 & 24.07 & 0.15 & 0.01 & 0.06 & 0.05 & 0.1 \\
\hline $5 \mathrm{R}-1,45-46$ & 34.36 & 0.16 & 0.01 & 0 & 0.04 & 0.12 \\
\hline $6 \mathrm{R}-1,66-67$ & 45.27 & 0.21 & 0 & 0 & 0.04 & 0.17 \\
\hline $8 \mathrm{R}-1,70-71$ & 63.51 & 0.09 & 0.01 & 0 & 0.07 & 0.02 \\
\hline 11R-CC, 4-5 & 101.15 & 0.05 & 0 & 0 & 0.05 & 0 \\
\hline 13R-CC, $12-13$ & 120.33 & 0.2 & 0.02 & 0 & 0.04 & 0.16 \\
\hline \multicolumn{7}{|l|}{ 169-1038D- } \\
\hline $1 \mathrm{R}-1,29-30$ & 0.3 & 1.15 & 0.09 & 0 & 0.89 & 0.26 \\
\hline $2 \mathrm{R}-1,26-27$ & 14.86 & 0.33 & 0.04 & 0.15 & 0.1 & 0.23 \\
\hline $3 \mathrm{R}-1,5-6$ & 24.65 & 0.24 & 0.02 & 0.15 & 0.04 & 0.2 \\
\hline \multicolumn{7}{|l|}{ 169-1038E- } \\
\hline 4R-1, 60-61 & 31.61 & 0.9 & 0.05 & 0 & 0.52 & 0.38 \\
\hline \multicolumn{7}{|l|}{$169-1038 \mathrm{~F}-$} \\
\hline $1 \mathrm{R}-\mathrm{CC}, 6-7$ & 9.56 & 0.84 & 0.04 & 0.13 & 0.48 & 0.36 \\
\hline $2 \mathrm{R}-1,59-60$ & 10.2 & 1.03 & 0.04 & 0 & 0.76 & 0.27 \\
\hline $2 \mathrm{R}-2,24-26$ & 11.85 & 1.16 & 0.06 & 0 & 0.81 & 0.35 \\
\hline $3 \mathrm{R}-1,120-121$ & 20.31 & 1.09 & 0.05 & 0 & 0.84 & 0.25 \\
\hline $3 \mathrm{R}-2,42-43$ & 21.03 & 1.06 & 0.05 & 0 & 0.81 & 0.25 \\
\hline $3 \mathrm{R}-3,49-50$ & 22.6 & 1.09 & 0.04 & 0 & 0.89 & 0.2 \\
\hline 3R-CC, 5-6 & 28.65 & 1.04 & 0.04 & 0 & 0.82 & 0.22 \\
\hline $4 \mathrm{R}-1,30-31$ & 29.01 & 0.89 & 0.05 & 0 & 0.61 & 0.28 \\
\hline 4R-CC, $0-8$ & 38.34 & 0.92 & 0.06 & 0 & 0.62 & 0.3 \\
\hline
\end{tabular}

169-1038G-

$3 \mathrm{H}-2,60-61$

$3 \mathrm{H}-4,49-50$

3H-6, 103-104

3H-8, 61-62

4H-2, 31-32

$4 \mathrm{H}-4,39-40$
$4 \mathrm{H}-7,18-19$

$4 \mathrm{H}-7,18-19$
$5 \mathrm{H}-1,50-51$

$5 \mathrm{H}-3,49-50$

5H-5, 49-50

6X-1, 70-71

$6 \mathrm{X}-1,70-71$
$6 \mathrm{X}-3,70-71$

6X-4, 126-127

$7 \mathrm{X}-1,68-68$
$8 \mathrm{X}-1,33-34$

9X-CC, $12-13$

$10 \mathrm{X}-1,21-22$

13X-CC, $10-11$

14X-CC, 9-10

$15 \mathrm{X}-\mathrm{CC}, 13-14$

\section{$24.11 \quad 1.15$}

$\begin{array}{ll}27 & 1.22 \\ 30.54 & 1.59\end{array}$

$\begin{array}{ll}30.54 & 1.59 \\ 31 & 1.17\end{array}$

33.32

$36.4 \quad 0.95$

$40.68 \quad 1.02$

$41.51 \quad 0.72$

$\begin{array}{ll}44.5 & 0.52 \\ 47.5 & 0.85\end{array}$

$51.21 \quad 0.54$

$\begin{array}{ll}51.21 & 0.54 \\ 54.21 & 0.47\end{array}$

$56.27 \quad 0.5$

$\begin{array}{ll}61.18 & 0.2 \\ 70.44 & 0.26\end{array}$

$\begin{array}{ll}70.44 & 0.26 \\ 89.03 & 0.21\end{array}$

$89.52 \quad 0.3$

0.3
0.24
0.47

$\begin{array}{ll}137.3 & 0.47 \\ 144.35 & 0.17\end{array}$

$169-1038 \mathrm{H}-$

$1 \mathrm{X}-1,30-31$

$1 \mathrm{X}-2,23-24$

1X-3, 25-26

$2 \mathrm{X}-2,16-17$

3X-1, 53-54

$3 \mathrm{X}-3,59-60$

$4 \mathrm{X}-1,71-72$

$4 \mathrm{X}-2,35-36$

$4 \mathrm{X}-4,102-103$

$5 \mathrm{X}-2,108-109$

5X-6, 49-50

6X-1, 35-36
$8 \mathrm{X}-\mathrm{CC}, 8-9$

14X-1, 15-16

14X-CC, 22-23

16X-CC, 14-15

20X-CC, $19-20$

\section{$\begin{array}{ll}0.31 & 0.18\end{array}$}

$\begin{array}{ll}0.31 & 0.18 \\ 1.74 & 0.06\end{array}$

3.26

$13.57 \quad 0.24$

$\begin{array}{ll}22.04 & 0.16\end{array}$

$\begin{array}{ll}25.1 & 0.2 \\ 30.52 & 0.65\end{array}$

$\begin{array}{ll}31.66 & 0.78\end{array}$

$\begin{array}{ll}35.33 & 0.78\end{array}$

$41.69 \quad 0.85$

$\begin{array}{ll}47.1 & 0.92\end{array}$

$49.06 \quad 0.76$

$\begin{array}{cc}77.5 & 0.61 \\ 125.76 & 0.66 \\ 135 & 0.53\end{array}$

135

$154.2 \quad 0.89$

169-1038I-

1X-1, 44-45

$1 X-1,55-56$
$1 X-3,60-61$

1X-4, 116-117

2X-1, 101-103

2X-3, 20-22

$3 \mathrm{H}-2,76-77$

3H-5, 37-38

$4 \mathrm{H}-2,76-77$

4H-6, 41-42

5H-2, 83-86

5H-5, 86-87

$5 \mathrm{H}-5,86-87$
$6 \mathrm{H}-2,72-73$

$6 \mathrm{H}-2,72-73$
$6 \mathrm{H}-5,30-31$

$6 \mathrm{H}-5,30-31$
$7 \mathrm{H}-2,69-70$

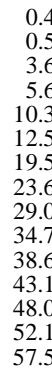


Table 11 (continued).

\begin{tabular}{|c|c|c|c|c|c|c|}
\hline $\begin{array}{l}\text { Core, section, } \\
\text { interval }(\mathrm{cm})\end{array}$ & $\begin{array}{l}\text { Depth } \\
\text { (mbsf) }\end{array}$ & $\begin{array}{c}\mathrm{TC} \\
(\mathrm{wt} \%)\end{array}$ & $\begin{array}{c}\mathrm{TN} \\
(\mathrm{wt} \%)\end{array}$ & $\begin{array}{c}\text { T S } \\
(\mathrm{wt} \%)\end{array}$ & $\begin{array}{c}\text { TIC } \\
\text { (wt } \%)\end{array}$ & $\begin{array}{c}\text { TOC } \\
\text { (wt } \%)\end{array}$ \\
\hline $7 \mathrm{H}-5,48-49$ & 61.79 & 0.82 & 0.04 & 0.03 & 0.52 & 0.3 \\
\hline $8 \mathrm{X}-1,111-112$ & 65.92 & 0.64 & 0.02 & 0 & 0.43 & 0.21 \\
\hline $8 X-3,113-114$ & 68.94 & 1.08 & 0.06 & 0.04 & 0.55 & 0.53 \\
\hline $8 X-5,113-114$ & 71.94 & 1.14 & 0.06 & 0 & 0.57 & 0.57 \\
\hline $9 \mathrm{X}-1,127-128$ & 75.68 & 1.01 & 0.04 & 0 & 0.57 & 0.44 \\
\hline $9 \mathrm{X}-2,80-81$ & 76.71 & 1 & 0.04 & 0 & 0.52 & 0.48 \\
\hline $10 X-1,1-2$ & 84.02 & 0.46 & 0.01 & 0 & 0.44 & 0.02 \\
\hline $11 X-6,50-51$ & 100.61 & 1.07 & 0.05 & 0 & 0.66 & 0.41 \\
\hline $12 \mathrm{X}-\mathrm{CC}, 3-4$ & 112.7 & 0.61 & 0.07 & 0.03 & 0.61 & 0.02 \\
\hline $16 \mathrm{X}-\mathrm{CC}, 22-23$ & 151.7 & 0.48 & 0.07 & 0 & 0.48 & 0.06 \\
\hline $17 X-1,47-48$ & 151.78 & 0.2 & 0.06 & 0.06 & 0.2 & 0.51 \\
\hline 17X-CC, 5-6 & 160.8 & 0.21 & 0.06 & 0 & 0.21 & 0.48 \\
\hline $18 \mathrm{X}-\mathrm{CC}, 10-11$ & 170.4 & 0.17 & 0.01 & 0 & 0.17 & 0.09 \\
\hline $19 X-1,52-53$ & 171.03 & 0.46 & 0.03 & 0 & 0.46 & 0.16 \\
\hline $20 X-1,15-16$ & 180.26 & 0.83 & 0.05 & 0 & 0.83 & 0.22 \\
\hline $21 X-1,63-64$ & 190.34 & 1.09 & 0.05 & 0 & 1.09 & 0.23 \\
\hline $22 \mathrm{X}-\mathrm{CC}, 7-8$ & 208.9 & 1.12 & 0.03 & 0 & 1.12 & 0.85 \\
\hline $23 \mathrm{X}-\mathrm{CC}, 16-17$ & 218.4 & 1.1 & 0.05 & 0 & 1.1 & 0.27 \\
\hline 24X-CC, 2-4 & 228.1 & 1.1 & 0.01 & 0 & 1.1 & 0.03 \\
\hline $28 X-1,78-79$ & 257.89 & 0.91 & 0.05 & 0 & 0.91 & 0.34 \\
\hline $28 X-3,59-60$ & 260.7 & 0.97 & 0.05 & 0 & 0.97 & 0.28 \\
\hline $29 X-2,80-81$ & 269.01 & 1 & 0.06 & 0 & 1 & 0.34 \\
\hline $29 X-5,83-84$ & 273.54 & 1.05 & 0.05 & 0 & 1.05 & 0.29 \\
\hline $31 X-1,111-112$ & 287.22 & 1.25 & 0.06 & 0 & 1.25 & 0.36 \\
\hline $31 X-4,111-112$ & 291.72 & 1.18 & 0.05 & 0 & 1.18 & 0.35 \\
\hline $32 X-1,50-51$ & 296.21 & 1.23 & 0.05 & 0 & 1.23 & 0.31 \\
\hline $32 X-3,34-35$ & 299.05 & 1.24 & 0.04 & 0 & 1.24 & 0.23 \\
\hline $33 X-2,86-87$ & 307.67 & 1.18 & 0.06 & 0 & 1.18 & 0.34 \\
\hline $33 X-5,67-68$ & 311.98 & 0.95 & 0.06 & 0 & 0.95 & 0.31 \\
\hline $34 \mathrm{X}-2,81-83$ & 317.22 & 0.97 & 0.05 & 0 & 0.97 & 0.27 \\
\hline $34 X-5,34-36$ & 321.25 & 0.98 & 0.05 & 0 & 0.98 & 0.29 \\
\hline $35 \times-2,78-79$ & 326.79 & 1.02 & 0.04 & 0 & 1.02 & 0.28 \\
\hline $36 \mathrm{X}-2,29-35$ & 325.92 & 0.99 & 0.05 & 0 & 0.99 & 0.32 \\
\hline $37 X-2,63-63$ & 345.83 & 0.98 & 0.06 & 0 & 0.98 & 0.36 \\
\hline $37 X-6,69-70$ & 350.9 & 1.06 & 0.05 & 0 & 1.06 & 0.29 \\
\hline $39 X-2,62-63$ & 365.03 & 0.93 & 0.06 & 0 & 0.93 & 0.32 \\
\hline $39 X-5,44-45$ & 369.35 & 0.91 & 0.06 & 0 & 0.91 & 0.36 \\
\hline $39 \times-7,36-37$ & 372.4 & 0.96 & 0.06 & 0 & 0.96 & 0.29 \\
\hline $40 X-1,61-62$ & 373.12 & 0.98 & 0.06 & 0 & 0.98 & 0.31 \\
\hline $40 X-5,40-41$ & 378.91 & 0.97 & 0.04 & 0 & 0.97 & 0.24 \\
\hline $41 X-3,56-57$ & 385.67 & 1.08 & 0.07 & 0 & 1.08 & 0.44 \\
\hline $42 X-3,31-32$ & 395.12 & 1.08 & 0.07 & 0 & 1.08 & 0.49 \\
\hline $42 X-5,36-38$ & 398.17 & 0.84 & 0.08 & 0 & 0.84 & 0.6 \\
\hline $43 X-1,85-86$ & 402.26 & 0.78 & 0.07 & 0 & 0.78 & 0.6 \\
\hline $43 X-2,68-69$ & 403.59 & 0.81 & 0.06 & 0 & 0.81 & 0.53 \\
\hline
\end{tabular}

Note: $\mathrm{TC}=$ total carbon, $\mathrm{TN}=$ total nitrogen, $\mathrm{TS}=$ total sulfur, $\mathrm{TIC}=$ total inorganic carbon, and $\mathrm{TOC}=$ total organic carbon

Hydrocarbons were found in Holes 1038B, 1038C, 1038E, 1038F, $1038 \mathrm{G}$, and $1038 \mathrm{H}$ (see "Organic Geochemistry" section, this chapter). The hydrocarbons were extremely thermally degraded, with the exception of those in Holes 1038F and 1038G, which had a suite of lighter, less degraded hydrocarbons. These short-chain hydrocarbons are potential food sources for hydrocarbon-oxidizing microorganisms, and enrichments for these organisms were attempted. The hydrocarbon-oxidizer medium consisted of artificial seawater amended with a nutrient/ trace element mixture (Baross, 1993) and a few drops of hexane. Some enrichments had yeast extract and small organic acids added as additional carbon sources, and all were incubated aerobically. Enrichments for hydrocarbon-oxidizers were attempted from locations rich in hydrocarbons in Sections 169-1038B-1R-1 and CC, 169-1038C-4R-CC, 169-1038D-1R-1, and 169-1038F-3R-1. Tubes inoculated with material from Section 169-1038F-3R-1 grew a $2-\mu \mathrm{m}$ squat rod at room temperature; as the organism grew in a culture medium without supplemental organics, it is likely a hydrocarbon-oxidizer. The same inoculum did not produce growth at $55^{\circ} \mathrm{C}$. With the exception of Section $169-1038 \mathrm{~B}-1 \mathrm{R}-1,50 \mathrm{~cm}$, which grew a large, 2- to $3-\mu \mathrm{M}$ coccoid in culture medium with extra organic sources, all other culture enrichments were negative. Holes that had degraded organics did not appear to support a community of hydrocarbon-oxidizing microorganisms.

Because enrichment cultures at Sites 1035, 1036, and 1037 had failed to provide any glimpse of the microbial community, more whole-round cores and selected section-top samples were preserved for DNA extraction than had previously been planned. Samples for

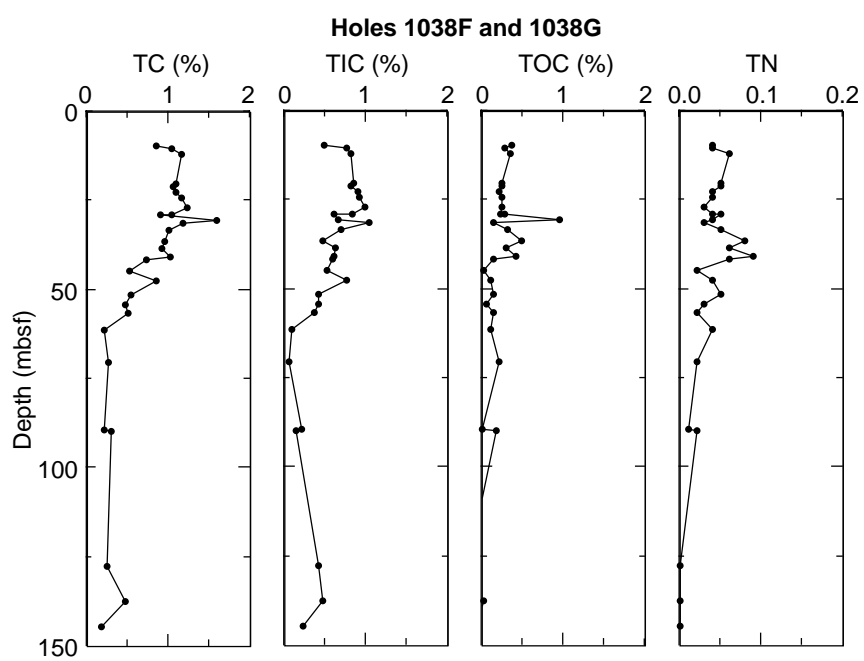

Figure 30. Percentages of TC, TIC, TOC, and TN vs. depth for sediments from Holes $1038 \mathrm{~F}$ and $1038 \mathrm{G}$.

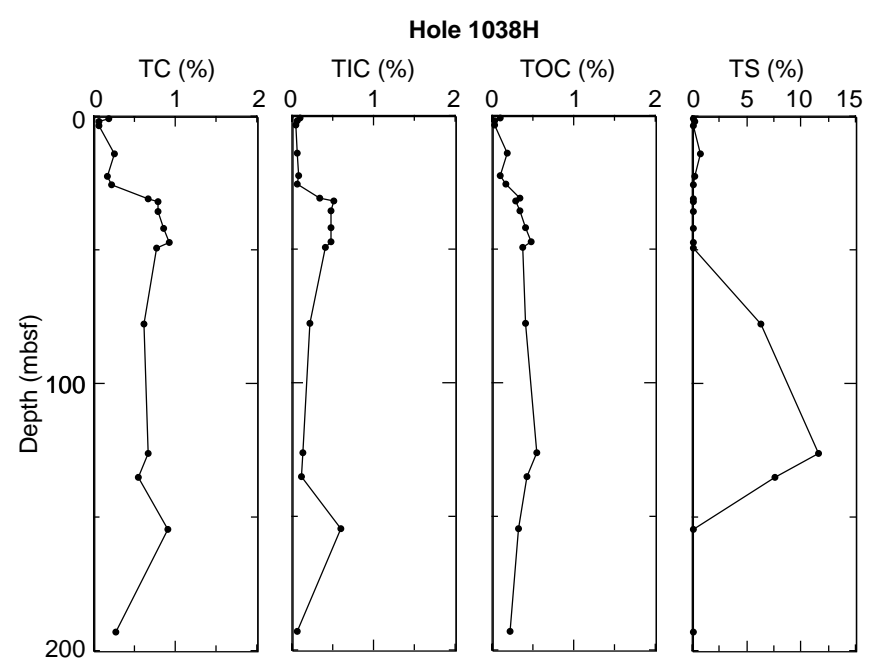

Figure 31. Percentages of TC, TIC, TOC, and TS vs. depth for sediments from Hole $1038 \mathrm{H}$

DNA analysis were preserved from Sections 169-1038E-4R-CC, 169-1038G-3H-1 and 4H-1, 169-1038H-1X-3, 169-1038I-4H-4, 5H$4,6 \mathrm{H}-4,7 \mathrm{H}-4,8 \mathrm{X}-4,9 \mathrm{X}-1$, and 11X-3. Section top samples were preserved for microbial abundance down to 53, 21, and $96 \mathrm{mbsf}$ for Holes 1038G, 1038H, and 1038I, respectively. Holes 1038A through $1038 \mathrm{~F}$ were drilled with the RCB, and the drilling disturbance was so great that preserving samples for microbial abundances was deemed inappropriate, because the probability for contamination of the cores with drilling fluids was high. No microbial counts were made aboard ship for this site.

\section{PHYSICAL PROPERTIES}

Physical properties measurements for Site 1038 included index properties and Multisensor Track (MST) measurements of magnetic susceptibility, gamma density, and natural gamma. Measurement of $P$-wave velocity with the MST below the upper few meters was precluded by the presence of gas in most of the cores. Index properties measurements are listed in Table 12 . Thermal conductivity measure- 
Figure 32. Percentages of TC, TS, TIC, and TOC vs. depth for sediments from Hole 1038I.
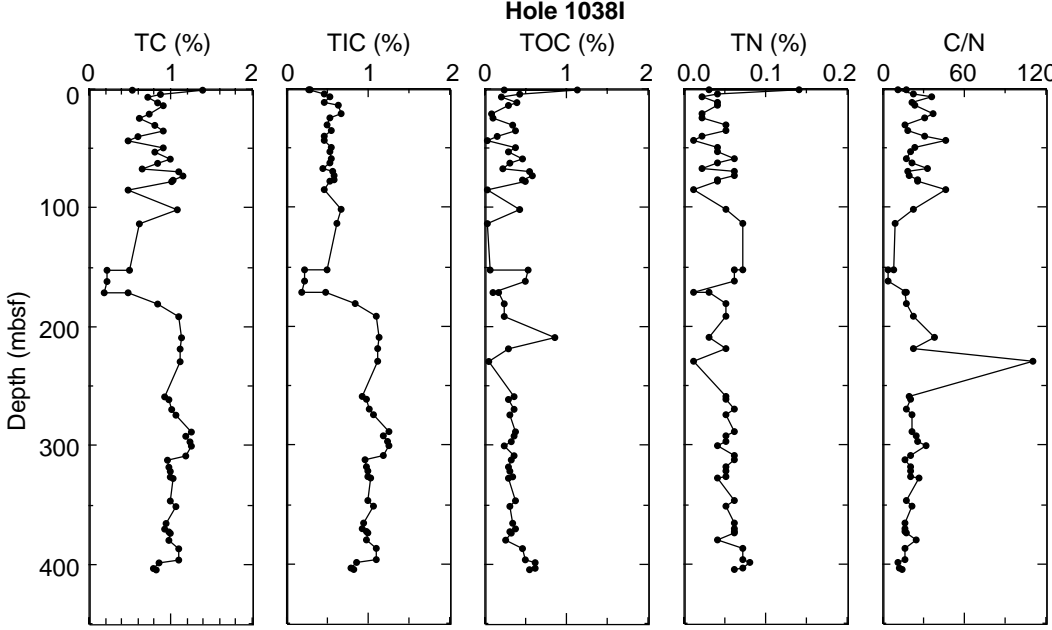

Table 12. Index properties measurements, Site 1038.

ments were made in cores, listed in Table 13, that were not significantly indurated. The most extensive data set is that for Hole 1038I, which will be described first. The other holes will be discussed in three groups determined by geographic proximity.

\section{Hole 1038I}

As in the reference site, Hole 1037B, the MST logs can be used to identify major and minor sedimentary units. Figure 33 illustrates the strong correlation between MST log signatures and other physical properties measurements in core from the upper $80 \mathrm{~m}$ of the hole. As shown on the figure, wet bulk density measurements and MST gamma density measurements are similar. The observed variations in porosity and thermal conductivity with depth indicate that these properties are strongly correlated with wet bulk density. Dashed lines correspond to depths at which significant changes in physical properties also coincide with the limits of turbidite beds identified based on grain size and other visual observations of the cores (see "Lithostratigraphy and Sedimentology" section, this chapter). These physical properties signatures also can be correlated to similar signatures observed in lithologic Unit II of Hole 1037B, as shown in Figure 34 .

Index properties measurements of porosity, wet bulk density, and grain density for the entire hole are shown in Figure 35. Porosity remains relatively constant, between $40 \%$ and $50 \%$ in the lower portion of the hole, with the exception of a very low porosity basalt core from the sample encountered at 162 mbsf. Grain densities are relatively constant, $\sim 2.8 \mathrm{~g} / \mathrm{cm}^{3}$ in the upper $100 \mathrm{~m}$ and lower $200 \mathrm{~m}$ from the hole, but show considerable scatter in the $50 \mathrm{~m}$ below the basalt.

MST records for the entire cored section of Hole 1038I are shown in Figure 36, along with magnetic susceptibility and natural gamma records for reference Hole 1037B. The high magnetic susceptibility peak at 162 mbsf in Hole 1038I is from measurements on a core containing basalt fragments (Section 169-1038I-18X-CC). The high magnetic susceptibilities at the bases of Holes 1037B and 1038I also correspond to basalts. Correlations in magnetic susceptibilities and natural gamma profiles between the two holes can be interpreted to indicate that they contain similar thicknesses of lithologic Unit VI, and that the sediments above the basalt at the base of Hole 1038I are part of lithologic Unit VII.

\section{Holes 1038A, 1038B, 1038E, and 1038H}

Figures 37-39 show the MST records for the holes that are located near relatively high-temperature vents to the northwest of Hole 1038I, that is, Holes 1038A, 1038B, 1038E, and 1038H. Limited re-

\begin{tabular}{|c|c|c|c|c|c|c|}
\hline $\begin{array}{l}\text { Core, section, } \\
\text { interval }(\mathrm{cm})\end{array}$ & $\begin{array}{l}\text { Depth } \\
\text { (mbsf) }\end{array}$ & $\begin{array}{c}\text { Porosity } \\
(\%)\end{array}$ & $\begin{array}{c}\text { Wet bulk } \\
\text { density } \\
\left(\mathrm{g} / \mathrm{cm}^{3}\right)\end{array}$ & $\begin{array}{l}\text { Grain density } \\
\left(\mathrm{g} / \mathrm{cm}^{3}\right)\end{array}$ & $\begin{array}{c}\text { Wet water } \\
\text { content } \\
(\%)\end{array}$ & $\begin{array}{l}\text { Void } \\
\text { ratio }\end{array}$ \\
\hline \multicolumn{7}{|l|}{ 169-1038A- } \\
\hline 2-CC, 4-6 & 8.54 & 62 & 1.76 & 2.97 & 36 & 1.66 \\
\hline $3-1,30-32$ & 18.50 & 78 & 1.55 & 3.37 & 52 & 3.50 \\
\hline $8-1,30-32$ & 66.90 & 49 & 1.90 & 2.74 & 27 & 0.97 \\
\hline $9-1,62-64$ & 76.82 & 47 & 2.07 & 3.01 & 23 & 0.90 \\
\hline \multicolumn{7}{|l|}{ 169-1038B- } \\
\hline $1-1,136-138$ & 1.36 & 75 & 1.52 & 2.99 & 32 & 2.95 \\
\hline $8-1,30-32$ & 63.10 & 57 & 1.82 & 2.86 & 32 & 1.31 \\
\hline $9-1,31-33$ & 72.71 & 45 & 2.06 & 2.92 & 23 & 0.83 \\
\hline $11-\mathrm{CC}, 5-7$ & 91.88 & 45 & 2.05 & 2.88 & 22 & 0.81 \\
\hline $12-1,17-19$ & 101.37 & 42 & 2.11 & 2.89 & 20 & 0.72 \\
\hline \multicolumn{7}{|l|}{ 169-1038C- } \\
\hline $1-1,26-28$ & 0.26 & 82 & 1.46 & 2.96 & 38 & 3.92 \\
\hline
\end{tabular}

Only part of this table is produced here. The entire table appears on CD-ROM.

Table 13. Thermal conductivity measurements, Site 1038.

\begin{tabular}{ccccccc}
\hline Hole & Core & Type & Section & $\begin{array}{c}\text { Position } \\
(\mathrm{cm})\end{array}$ & $\begin{array}{c}\text { Depth } \\
(\mathrm{mbsf})\end{array}$ & $\begin{array}{c}\text { Thermal conductivity } \\
(\mathrm{W} /[\mathrm{m} \cdot \mathrm{K}])\end{array}$ \\
\hline $\mathrm{C}$ & 3 & $\mathrm{R}$ & 1 & 60 & 23.20 & 1.12 \\
$\mathrm{E}$ & 4 & $\mathrm{R}$ & 2 & 25 & 32.75 & 1.02 \\
$\mathrm{E}$ & 4 & $\mathrm{R}$ & 1 & 130 & 32.30 & 1.21 \\
$\mathrm{E}$ & 4 & $\mathrm{R}$ & 2 & 30 & 32.80 & 1.10 \\
$\mathrm{G}$ & 3 & $\mathrm{H}$ & 2 & 39 & 22.69 & 0.96 \\
$\mathrm{G}$ & 3 & $\mathrm{H}$ & 5 & 60 & 27.40 & 1.06 \\
$\mathrm{G}$ & 3 & $\mathrm{H}$ & 6 & 40 & 28.70 & 1.17 \\
$\mathrm{G}$ & 4 & $\mathrm{H}$ & 3 & 56 & 35.06 & 0.96 \\
$\mathrm{G}$ & 4 & $\mathrm{H}$ & 4 & 67 & 36.67 & 1.17 \\
$\mathrm{G}$ & 4 & $\mathrm{H}$ & 6 & 58 & 38.30 & 1.03 \\
\hline
\end{tabular}

Only part of this table is produced here. The entire table appears on CD-ROM.

covery in all four holes made these records discontinuous. High magnetic susceptibilities were measured in cores from just below the seafloor in Holes 1038A and 1038H and slightly deeper in Hole 1038B within the zones from which sulfide was recovered. Natural gamma measurements exceeding 100 total counts per second in Cores 1691038H-1X, 2X, and 1038B-1R, are associated with sulfide clasts, presumably the result of associated barite, which incorporates ${ }^{226} \mathrm{Ra}$ into its structure. Beneath the sulfide zones, at $\sim 17 \mathrm{mbsf}$ in Hole $1038 \mathrm{H}$ and at $\sim 30 \mathrm{mbsf}$ in Hole 1038B, there appear to be magnetic "wipe-out" zones. Magnetic susceptibility peaks in the tops of cores from deeper in Hole $1038 \mathrm{H}$ are primarily caused by sulfide rubble that likely originated higher in the hole. Gamma density highs at these same depths are also the result of sulfide rubble. 


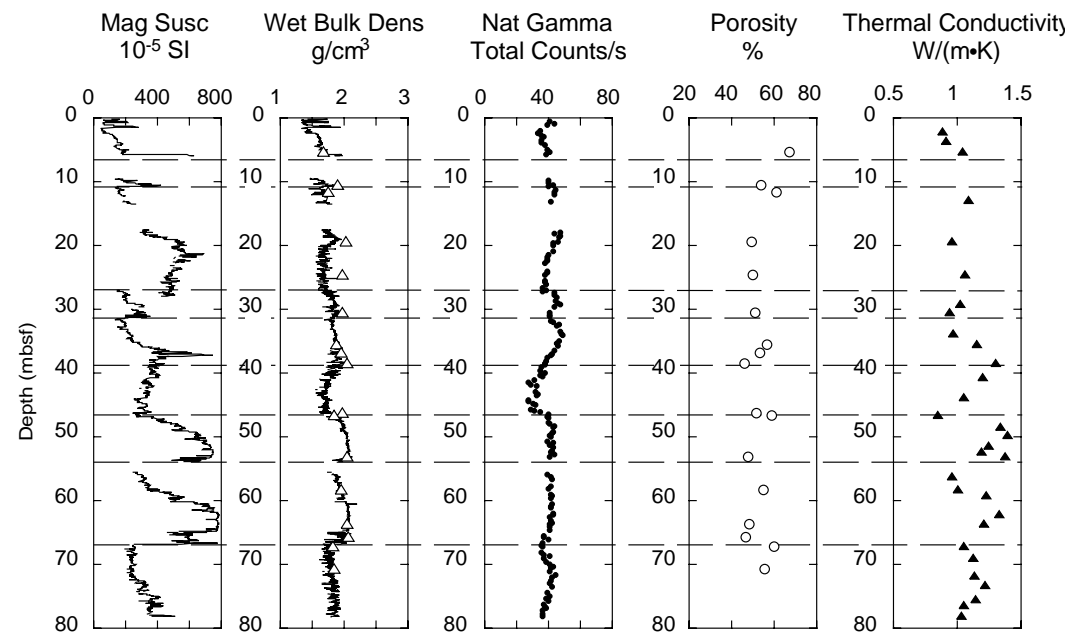

Figure 33. Physical properties measurements for the upper $80 \mathrm{mbsf}$ at Hole 1038I. Magnetic susceptibility, gamma density (solid lines on wet bulk density plot), and natural gamma were measured with the MST. Open triangles = index properties measurements of wet bulk density, open circles $=$ porosity, solid triangles $=$ thermal conductivity measurements that were made on unlithified sediment using a full-space needle probe, and dashed lines $=$ depths where changes in physical properties coincide with limits of turbidite beds identified based on visual core descriptions.

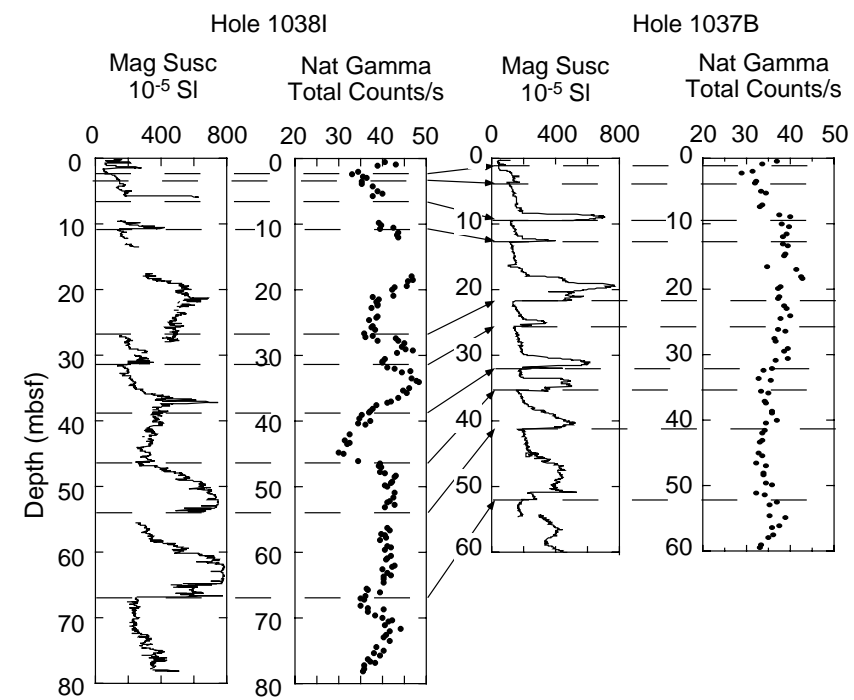

Figure 34. Correlations between magnetic susceptibility and natural gamma MST records for turbidites of lithologic Unit II in Holes 1038I and 1037B. Dashed lines on records for a given hole $=$ major breaks in the MST profiles. Arrows between records for the two holes = tentative correlations based on similarities in the profiles.

A limited number of index wet bulk density measurements made on samples from these holes compare quite well to gamma density records from the MST, as shown in Figure 38. With the exception of a sample from Hole 1038A (Sample 169-1038A-3R-1, 30-32 cm), which may have contained some sulfide, other index properties measurements (see Fig. 40) indicate decreases in porosity from $>60 \%$ near the seafloor to $\sim 40 \%$ at $80 \mathrm{mbsf}$ and relatively constant grain densities between 2.7 and $3.0 \mathrm{~g} / \mathrm{cm}^{3}$.

\section{Holes 1038C and 1038D}

Very limited recovery from these two holes, located to the north of Hole 1038A, precluded extensive physical properties measurements. MST measurements of magnetic susceptibility and natural gamma are shown in Figure 41. The most interesting feature of these records is the high natural gamma measured in Core 169-1038C-1R. Index properties measurements (see Fig. 42) were made only on three samples from Hole 1038C, and no index properties samples were collected from Hole 1038D. Index wet bulk densities are consistent with gamma densities measured by the MST for Hole 1038C.

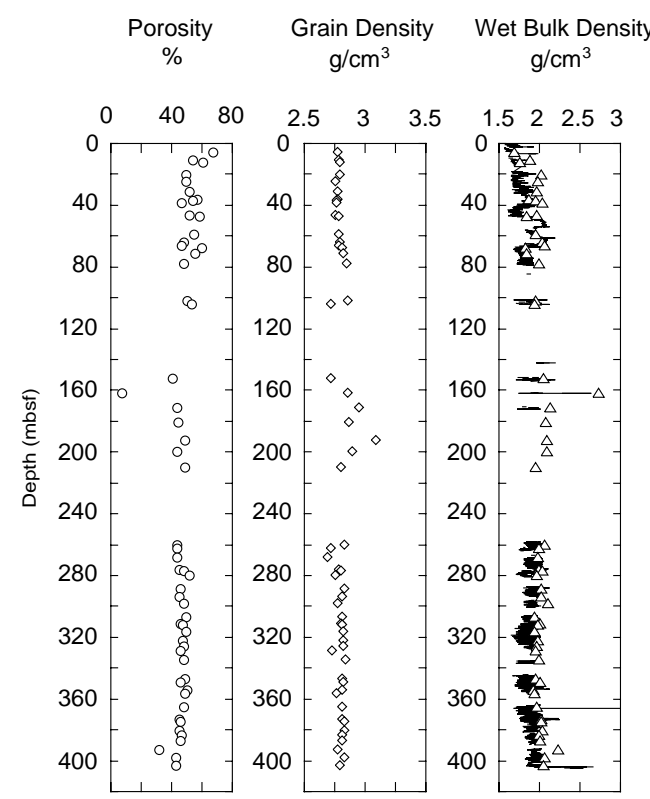

Figure 35. Index properties measurement profiles for Hole 1038I. Open circles $=$ porosity measurements, open diamonds $=$ grain density, and open triangles $=$ wet bulk density. Solid lines $=$ gamma densities measured with the MST as shown on the plot of wet bulk density.

\section{Holes 1038F and 1038G}

MST measurements for Holes $1038 \mathrm{~F}$ and $1038 \mathrm{G}$, both located near a zone of diffuse low-temperature venting, are summarized graphically in Figure 43. Low magnetic susceptibilities below $\sim 30$ mbsf in both holes may reflect a magnetic wipe-out similar to that observed at the Dead Dog sites. Variability in the gamma density records primarily reflects the biscuited nature of much of the recovered core. Density appears to increase, with maximum values above $2 \mathrm{~g} / \mathrm{cm}^{3}$, below $70 \mathrm{mbsf}$. Index properties wet bulk densities, plotted along with the gamma density, indicate that true densities are approximated by the upper limit of the measured gamma density in any interval, except in the basalt from the bottom of Hole 1038G, where gamma densities are significantly lower than the index properties wet bulk densities. This occurs because there is no correction applied to account for the fact that the diameter of the rock sections are significantly less than the inside liner diameter. Consequently, index properties values of density more accurately reflect the in situ values. Nat- 
Figure 36. MST profiles of magnetic susceptibility, gamma density, and natural gamma for Hole 1038I. Also shown for reference are MST profiles of magnetic susceptibility and natural gamma for Hole 1037B. Dashed lines $=$ tentatively identified upper and lower boundaries of lithologic Unit VI.
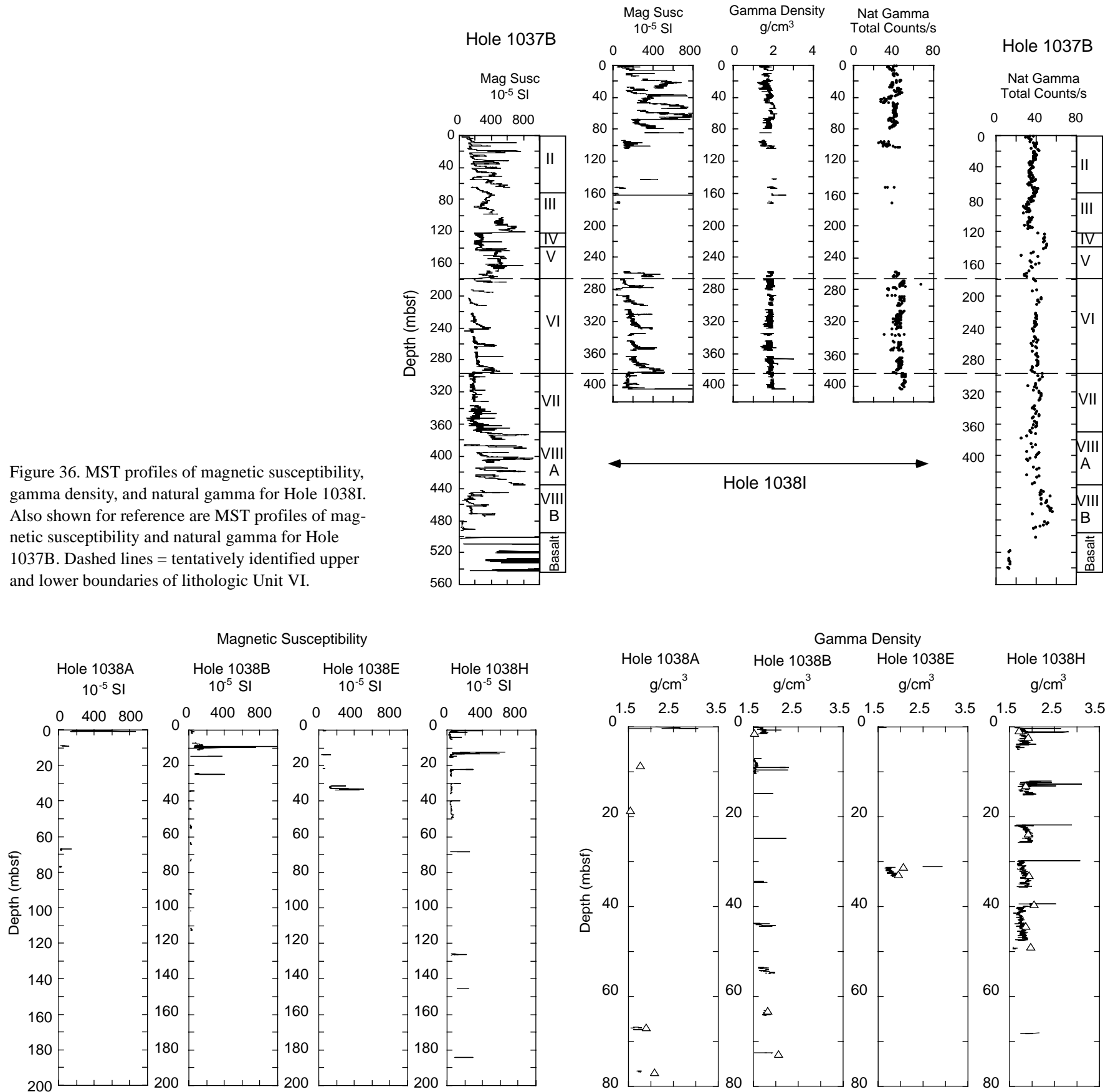

Figure 37. MST measurements of magnetic susceptibility measurements for Holes 1038A, 1038B, 1038E, and 1038H.

ural gamma appears to be relatively constant with depth in the upper $70 \mathrm{mbsf}$, at $\sim 40$ total counts per second, then drops to $\sim 20$ total counts per second in the lower portion of Hole 1038G.

Porosities and grain densities for these two holes are shown graphically in Figure 44. Grain densities are fairly constant, $\sim 2.8 \mathrm{~g} /$ $\mathrm{cm}^{3}$ in the sediments, but increase slightly in the basalt. Porosity is $\sim 70 \%$ in the shallowest samples from Hole $1038 \mathrm{~F}$ and remains near $50 \%$ in the upper 90 mbsf. An abrupt decrease in porosity can be seen in the altered sediment and basalt from the base of Hole 1038G. Ther-

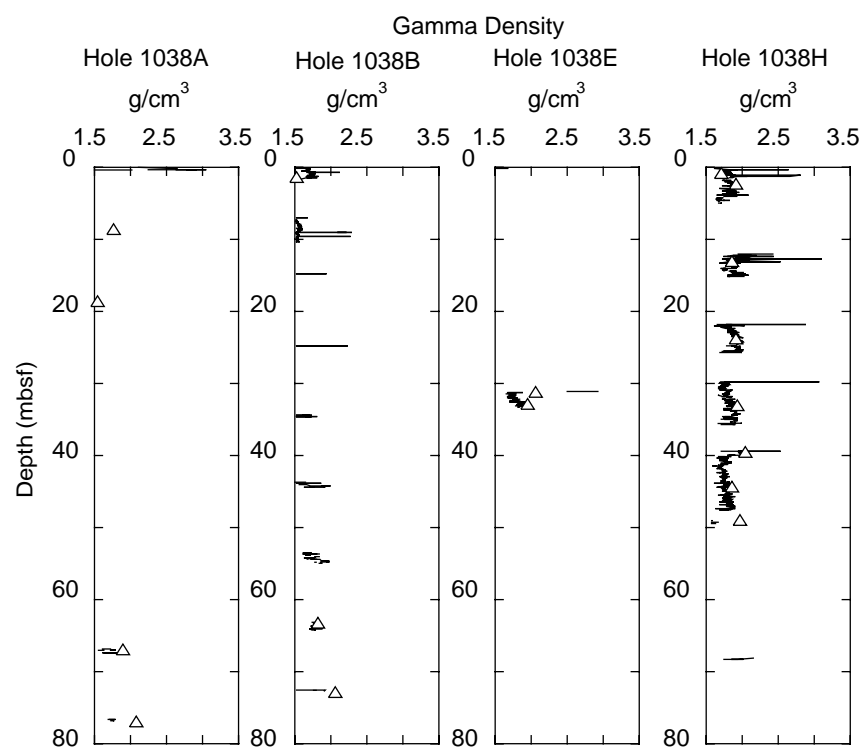

Figure 38 . Wet bulk density measurements for Holes 1038A, 1038B, 1038E, and $1038 \mathrm{H}$. Solid lines = MST measurements of gamma density, and open triangles $=$ index properties measurements.

mal conductivities for Hole $1038 \mathrm{G}$ (see Fig. 45 ) are $\sim 1 \mathrm{~W} /(\mathrm{m} \cdot \mathrm{K}$ ) with no obvious trends with depth.

Time constraints and an inappropriate bottom-hole assembly precluded implementation of the original logging plan, and the only downhole measurements made over the Central Hill area were two

\section{DOWNHOLE MEASUREMENTS}




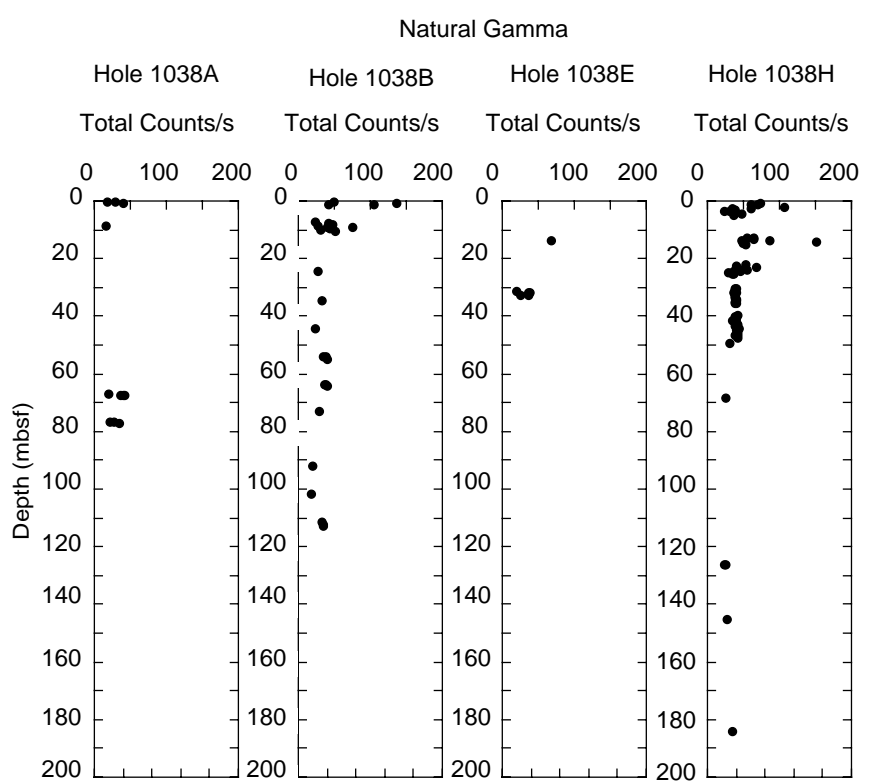

Figure 39. MST measurements of natural gamma for Holes 1038A, 1038B, $1038 \mathrm{E}$, and $1038 \mathrm{H}$.

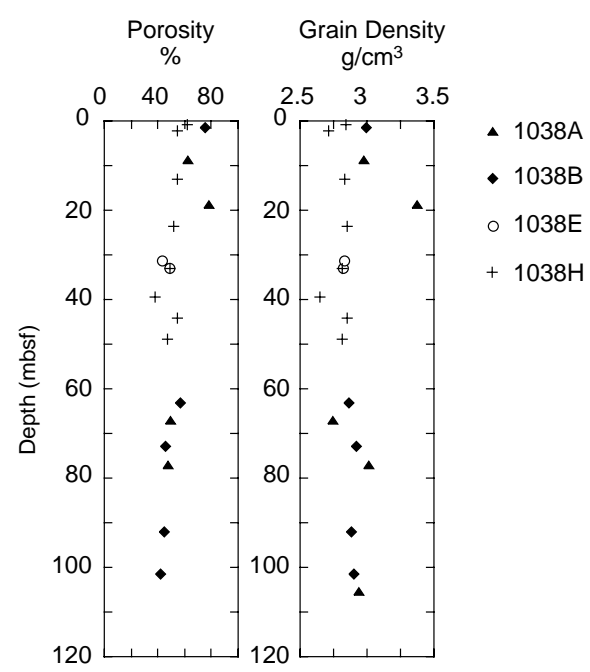

Figure 40. Index properties measurements of porosity and grain density for Holes 1038A (solid triangles), 1038B (solid diamonds), 1038E (open circles), and $1038 \mathrm{H}$ (+ symbols).

temperature measurements in Hole 1038I with the Adara and DavisVillinger temperature probes (DVTP; see "Explanatory Notes" chapter, this volume). The temperature records of these two deployments are displayed in Figure 46. The extrapolated formation temperatures, summarized in Table 14 and Figure 47, show a temperature gradient of $2.0^{\circ} \mathrm{C} / \mathrm{m}$.

To estimate the nature of the thermal regime at this site, we also examined the relationship between the temperature and the thermal resistance of the formation. The thermal resistance over an interval can be calculated by a discrete integration of the thermal conductivities measured on core samples over this interval (Davis, Mottl, Fisher, et al., 1992). In a purely conductive regime, a plot of temperature vs. thermal resistance would be linear, with the heat flow given by the slope of the line, and any fluctuation around this line would be indicative of the presence of other modes of heat transfer. Figure 47B

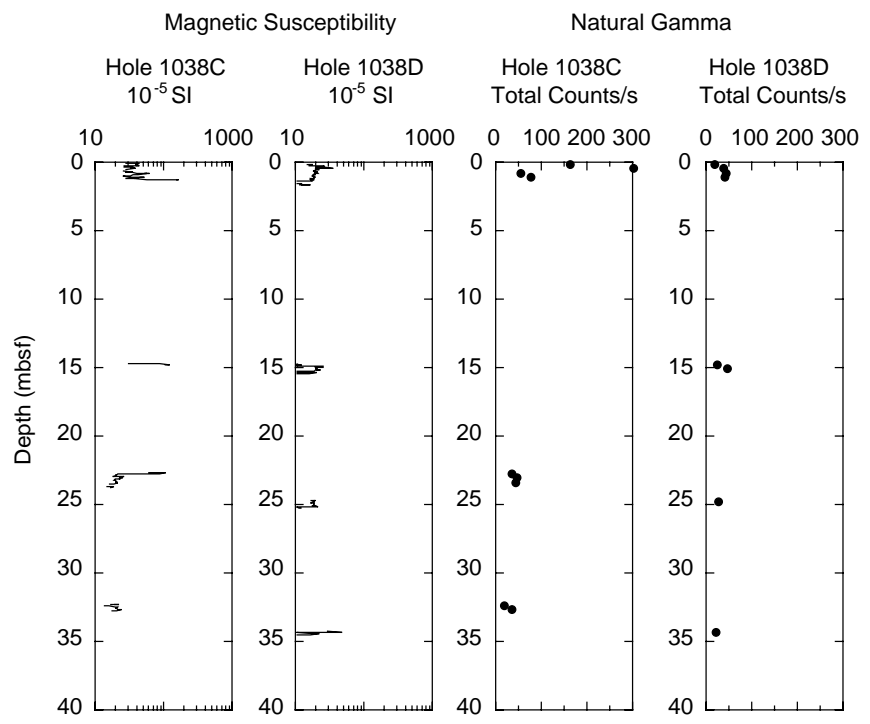

Figure 41. MST measurements of magnetic susceptibility (solid lines) and natural gamma (solid circles) for Holes 1038C and 1038D.

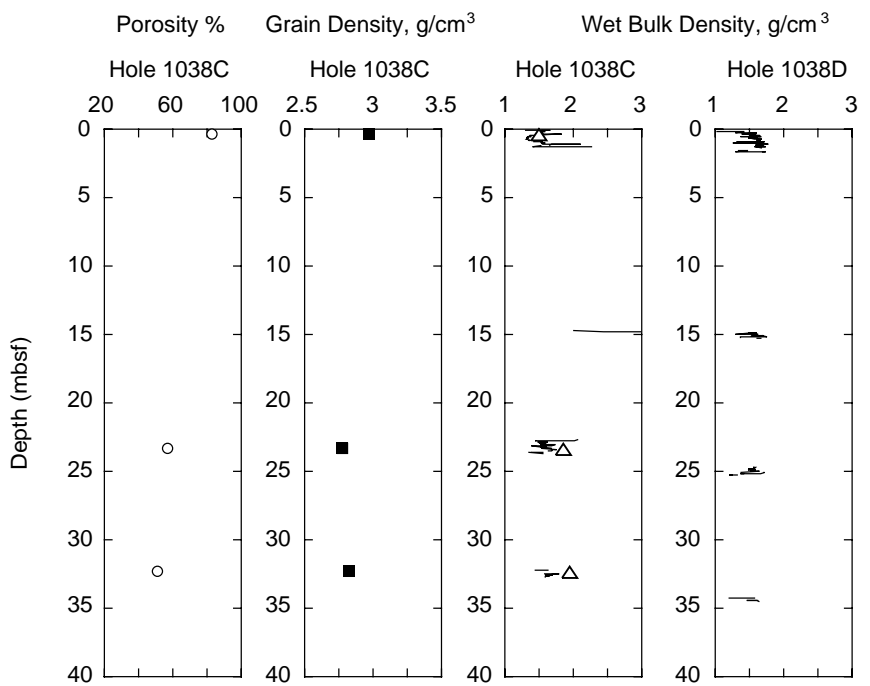

Figure 42. Index properties measurements of porosity (open circles), grain density (solid squares), and wet bulk density (open triangles) for Hole 1038C. Solid lines $=$ MST measurements of gamma density for Holes $1038 \mathrm{C}$ and 1038D.

shows the relationship between temperature and thermal resistance in Hole 1038I, and the slope of the linear fit gives a value for the conductive heat flow of $2.16 \mathrm{~W} / \mathrm{m}^{2}$. Despite the limited amount of data, the closeness of the linear fit suggests that the regime could be entirely conductive.

\section{PALEOMAGNETISM}

Recovery in Hole $1038 \mathrm{G}$ permitted measurements on the passthrough magnetometer for whole sections of split core only over several intervals from 22 to 62 mbsf. Rejection criteria included drillinginduced core disturbances as well as disturbances of the sedimentary fabric because of extensive gas expansion throughout Hole 1038G. Sections $169-1038 \mathrm{G}-5 \mathrm{H}-3$ through $5 \mathrm{H}-6$ had to be pumped from the 


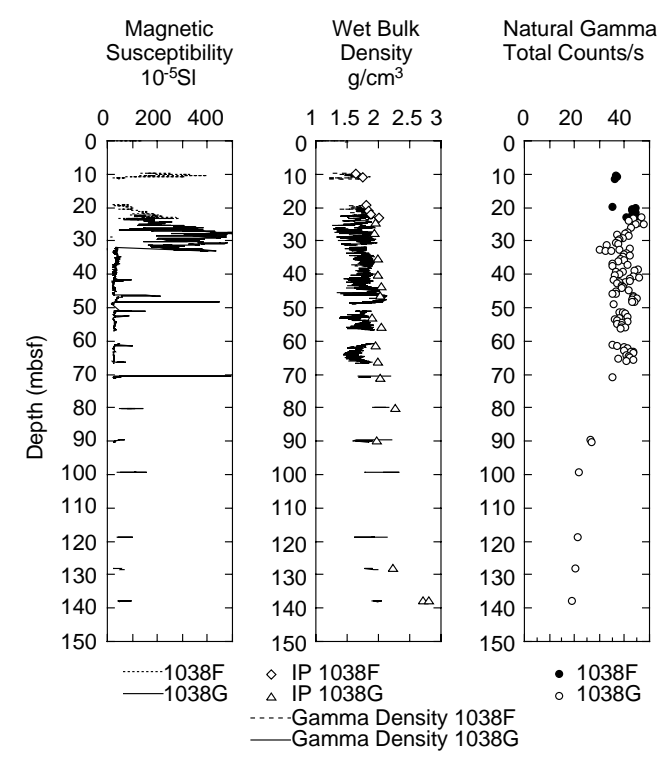

Figure 43. MST measurements of magnetic susceptibility, wet bulk density, and natural gamma for Holes 1038F and 1038G. Index properties measurements of wet bulk density (open diamonds and open triangles) are shown along with gamma density records.

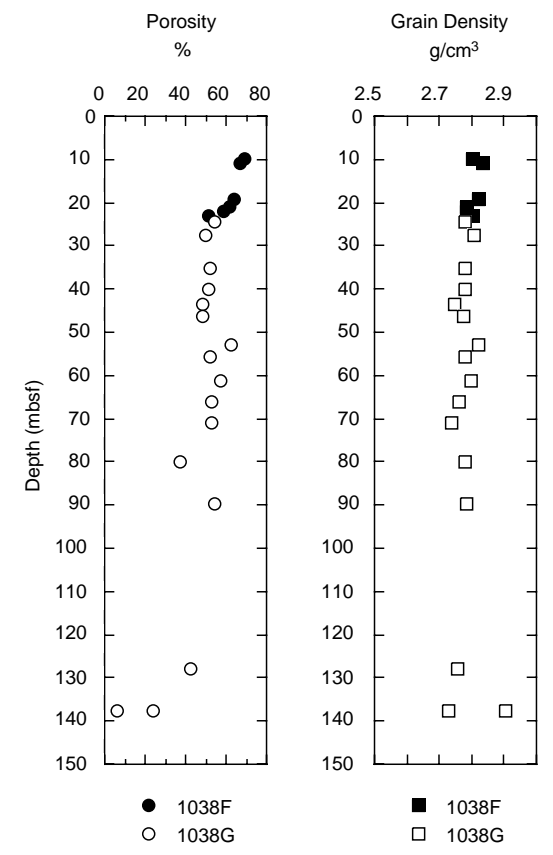

Figure 44. Index properties measurements of porosity and grain density for Holes 1038F (solid circles and squares) and 1038G (open circles and squares).

core barrel, thus rendering paleomagnetic measurements impossible. The paleomagnetic signal at Hole 1038I could only be measured for Cores 169-1038I-1X through 9X, as well as for a short interval at the bottom of Core 169-1038I-11X. Patches of the natural remanent magnetization were also recorded for Sections 169-1038H-5X-1 through 5X-5 and Sections 169-1038B-13X-1 through 13X-CC.

\section{Hole 1038G}

The magnetic intensity of Hole $1038 \mathrm{G}$ cores demagnetized with an alternating field (AF) of $20 \mathrm{mT}$ is on the order of several hundred $\mathrm{mA} / \mathrm{m}$ in the upper part of the hole between 20 and $40 \mathrm{mbsf}$ (Fig. 48). The paleomagnetic signal at Hole $1038 \mathrm{G}$ is characterized by a dis-

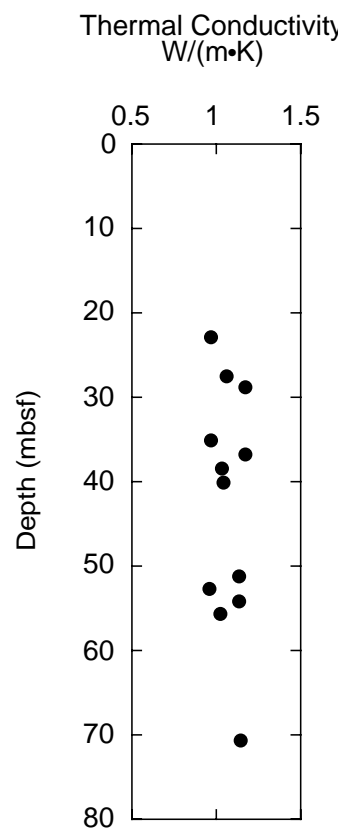

Figure 45. Thermal conductivity measurements for Hole 1038G.

tinct drop in magnetization intensity (almost 1 order of magnitude) below 40 mbsf. The signal decreases continuously between 40 and 42 mbsf, and then the intensity remains weak below this depth to 62 mbsf. Interestingly, a distinct drop in magnetic susceptibility is recorded at $\sim 30$ mbsf, preceding the drop in intensity by $\sim 10 \mathrm{~m}$ (see "Physical Properties" section, this chapter). This could point to an authigenic component with a higher alignment efficiency as the carrier of the remanent magnetic signal between 30 and 40 mbsf. Despite an effective demagnetization by the 20-mT step, the intensities on the $\mathrm{z}$-axis remain almost 1 order of magnitude higher when compared to the $\mathrm{x}$ - and $\mathrm{y}$-axes, resulting in steep positive inclinations downhole. Whether gas expansion or hydrothermal alteration of the sediments contributes to these spurious magnetization directions cannot be determined presently. The entire interval covered by paleomagnetic measurements at Hole $1038 \mathrm{G}$ is composed of moderately altered sediments of lithologic Unit II, with carbonate concretions and cements of alteration Facies $b$ (see "Lithostratigraphy and Sedimentology" section, this chapter; Fig. 48). Declinations shown in Figure 48 are not oriented with respect to geographic north and only display the relative rotation of continuous core sections.

\section{Hole 1038I}

Lithologically, the upper part of Hole $1038 \mathrm{I}(0-75 \mathrm{mbsf})$ is composed of unaltered to moderately altered, hemipelagic to turbiditic sediments of Unit II (see "Lithostratigraphy and Sedimentology" section, this chapter). The magnetic inclination, after AF demagnetization at $20 \mathrm{mT}$, throughout this interval indicates a normal polarity of the Earth's magnetic field and generally suggests a magnetization of the sediments during the Brunhes Chron (Fig. 48). The paleomagnetic signal at Hole 1038I yields meter-scale intervals, displaying relatively homogeneous directions (largely scattered around the expected mean value of $67^{\circ}$ for this site) and is comparable to the magnetic inclination pattern recorded in cores from the Escanaba Trough Reference Site (Hole 1037B; see "Paleomagnetism" section, "Escanaba Trough Reference Site" chapter, this volume). Distinct offsets in inclination between these intervals may reflect alternation of turbiditic and hemipelagic sediments. Despite these similarities, no significant correlation can be made between the sediments of Hole 1038I and the Escanaba Trough Reference Site. 
A
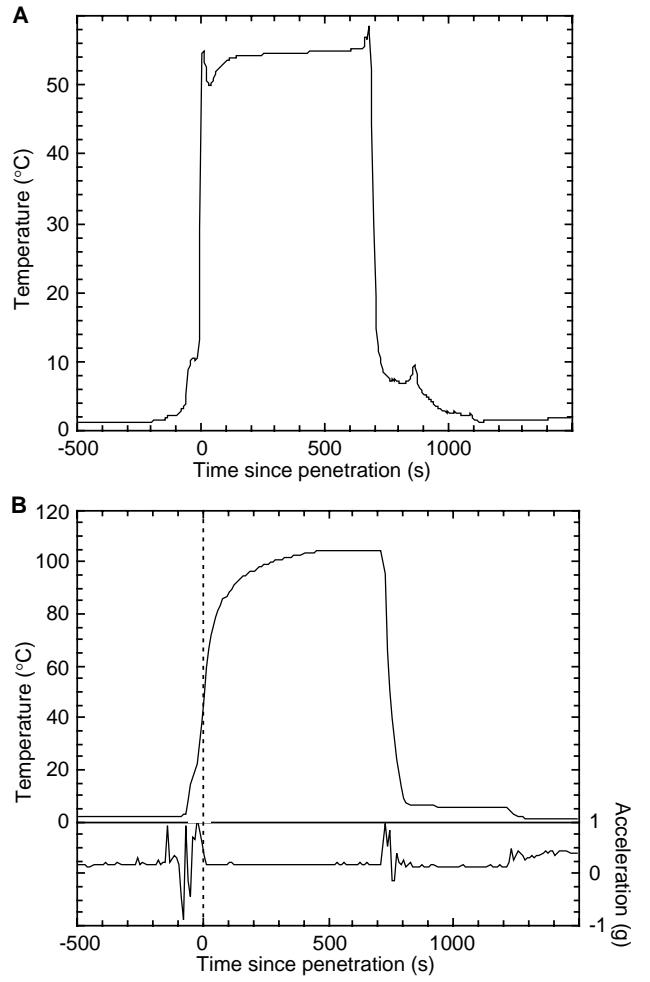

Figure 46. Temperature records of the (A) Adara and (B) DVTP tools in Hole 1038I. A synthetic theoretical decay curve fit is applied to the portion of these curves corresponding to the time spent by the probe in the sediments to extrapolate the equilibrium temperature. The exact time of penetration of the DVTP probe is picked using the tool's accelerometer record, displayed in the same figure.

Table 14. Summary of temperature measurements, Hole 1038 I.

\begin{tabular}{ccc}
\hline Type of tool & $\begin{array}{c}\text { Depth } \\
(\mathrm{mbsf})\end{array}$ & $\begin{array}{c}\text { Temperature } \\
\left({ }^{\circ} \mathrm{C}\right)\end{array}$ \\
\hline Adara & 28.3 & 55.7 \\
DVTP & 56.8 & 115.9 \\
\hline
\end{tabular}

Note: DVTP = Davis-Villinger temperature probe.

The magnetic intensity after 20-mT demagnetization of cores from Hole $1038 \mathrm{I}$ is on the order of several hundred $\mathrm{mA} / \mathrm{m}$. A distinct drop in magnetization intensity between 36 and $42 \mathrm{mbsf}$ is recorded at about the same depth as a similar decrease in intensities measured in Hole 1038G. Unlike Hole 1038G, magnetization intensities at Hole 1038I remain on the order of several hundred $\mathrm{mA} / \mathrm{m}$ below 42 mbsf (Fig. 48). A second distinct drop in magnetization intensities in cores from Hole 1038I is recorded at $\sim 74$ mbsf. Unfortunately, recovery did not permit further continuous pass-through measurements below this depth, so that it is unknown whether the intensities remain low. A relationship between major downhole changes of magnetization intensities and the hydrothermal alteration of the sediments is not evident. For example, correlating the concomitant intensity drops at $40 \mathrm{mbsf}$ in cores from Holes $1038 \mathrm{G}$ and $1038 \mathrm{I}$ more likely suggests a change in the primary detrital input as a cause of the magnetic signal at this depth. Whether hydrothermal decomposition of the carriers of the remanent magnetization caused any alteration of the paleomagnetic signal needs to be addressed in a post-cruise study.
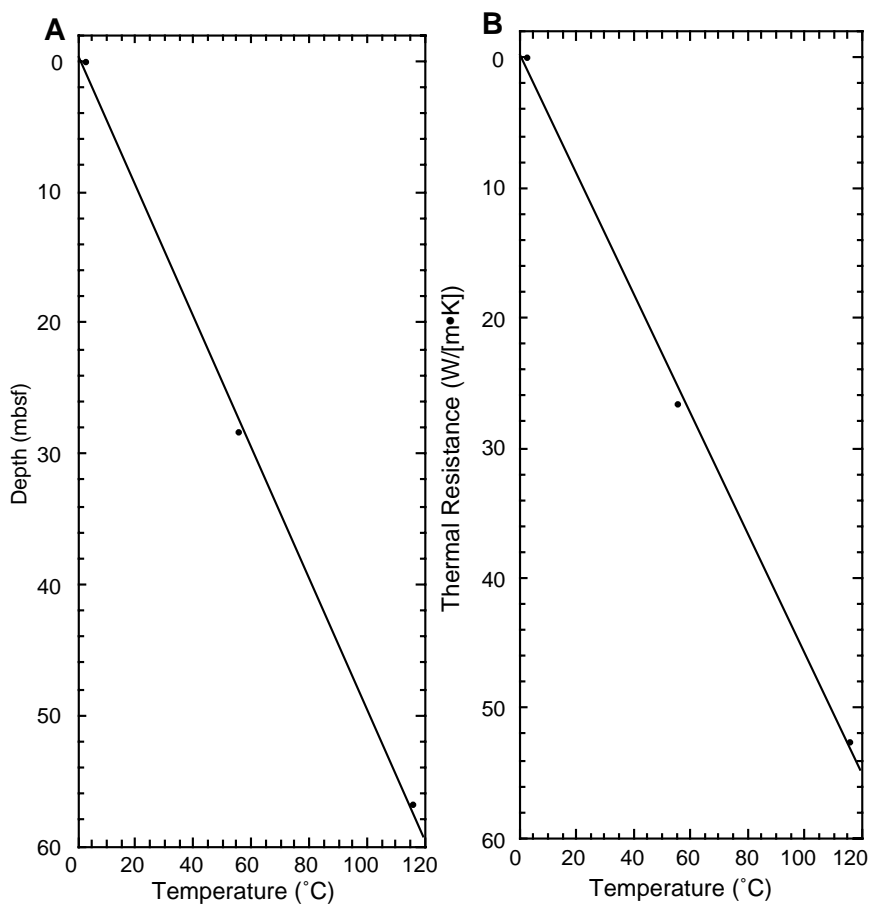

Figure 47. Temperature measurements in Hole 1038I vs. (A) depth and (B) thermal resistance. The average gradient in (A) is $2.0^{\circ} \mathrm{C} / \mathrm{m}$. The least-squares linear fit in (B) suggests a purely conductive regime with a vertical flux of $2.16 \mathrm{~W} / \mathrm{m}^{2}$.

\section{Conclusions}

Holes 1038G, 1038I, and 1037B (Reference Site) have been sampled for a post-cruise high-resolution rock magnetic study. Diagenetic and magneto-mineralogical aspects of the downhole variations of the magnetic signal will be addressed, thus providing a sound basis for interpretation of the magnetic signal that will aid in a site-to-site correlation.

\section{REFERENCES}

Abbott, D.H., Morton, J.L., and Holmes, M.L., 1986. Heat-flow measurements on a hydrothermally active, slow-spreading ridge: the Escanaba Trough. Geophys. Res. Lett., 13:678-680.

Atwater, T., and Mudie, J.D., 1973. Detailed near-bottom geophysical study of the Gorda Ridge. J. Geophys. Res., 78:8665-8683.

Baross, J.A., 1993. Isolation and cultivation of hyperthermophilic bacteria from marine and freshwater habitats. In Kemp, P.F., Sherr, B.F., and Sherr, E.B, and Cole, J.J. (Eds.), Handbook of Methods in Aquatic Microbial Ecology: New York (Academic Press), 21-30.

Baross, J.A., and Deming, J.W., 1995. Growth at high temperatures: isolation and taxonomy, physiology, ecology. In Karl, D.M. (Ed.), The Microbiology of Deep-sea Hydrothermal Vent Environments: Boca Raton, FL (CRC Press), 169-217.

Bernard, B.B., Brooks, J.M., and Sackett, W.M., 1976. Natural gas seepage in the Gulf of Mexico. Earth Planet. Sci. Lett., 31:48-54.

Bischoff, J.L., and Dickson, F.W., 1975. Seawater-basalt interaction at $200^{\circ} \mathrm{C}$ and 500 bars: implications for origin of seafloor heavy metal deposits and regulation of seawater chemistry. Earth Planet. Sci. Lett., 25:385-397.

Böhlke, J.K., and Shanks, W.C., III., 1994. Stable isotope study of hydrothermal vents at Escanaba Trough: observed and calculated effects of sediment-seawater interaction. In Morton, J.L., Zierenberg, R.A., and Reiss, C.A. (Eds.), Geologic, Hydrothermal and Biologic Studies at Escanaba Trough, Gorda Ridge, Offshore Northern California. U.S. Geol. Surv. Bull., 2022:223-239. 
Bowers, T.S., Von Damm, K.L., and Edmond, J.M., 1985. Chemical evolution of mid-ocean ridge hot springs. Geochim. Cosmochim. Acta, 49:2239-2252.

Campbell, A.C., German, C.R., Palmer, M.R., Gamo, T., and Edmond, J.M., 1994. Chemistry of hydrothermal fluids from the Escanaba Trough, Gorda Ridge. In Morton, J.L., Zierenberg, R.A., Reiss, C.A. (Eds.), Geologic, hydrothermal, and biologic studies at Escanaba Trough, Gorda Ridge, offshore Northern California. U.S. Geol. Surv. Bull., 2022:201221.

Chan, L.H., Gieskes, J.M., You, C.F. and Edmond, J.M., 1994. Lithium isotope geochemistry of sediments and hydrothermal fluids of the Guaymas Basin, Gulf of California, Geochim. Cosmochim. Acta, 58:4443-4454.

Clague, D.A., and Holmes, M.L., 1987. Geology, petrology, and mineral potential of the Gorda Ridge: U.S. Geol. In Scholl, D.W., Grantz, A., and Vedder, J.G. (Eds.), Geology and Resources Potential of the Continental Margin of Western North American Adjacent Ocean Basins-Beaufort Sea to Baja California. Circum-Pac. Counc. Energy Miner. Res., Earth Sci. Ser., 6:563-580.

Davis, E.E., and Becker, K., 1994. Thermal and tectonic structure of the Escanaba Trough: new heat-flow measurements and seismic-reflection profiles. In Moreton, J., Zierenberg, R.A., and Reiss, C.A. (Eds.), Geologic, Hydrothermal, and Biologic Studies at Escanaba Trough, Gorda Ridge, Offshore Northern California. U.S. Geol. Surv. Bull., 2022:4564.

Davis, E.E., Mottl, M.J., Fisher, A.T., et al., 1992. Proc. ODP, Init. Repts., 139: College Station, TX (Ocean Drilling Program).

Denlinger, P., and Holmes, M.L., 1994. A thermal and mechanical model for sediment hills and associated sulfide deposits along Escanaba Trough. In Morton, J.L., Zierenberg, R.A., and Reiss, C.A. (Eds.), Geologic, Hydrothermal, and Biologic Studies at Escanaba Trough, Gorda Ridge, Offshore Northern California. U.S. Geol. Surv. Bull., 2022:65-75.

Didyk, B.M., Simoneit, B.R.T., Brassell, S.C., and Eglinton, G., 1978. Organic geochemical indicators of palaeoenvironmental conditions of sedimentation. Nature, 272:216-222.

Einsele, G., Gieskes, J.M., Curray, J., Moore, D.M., Aguago, E., Aubry, M.P., Fornari, D., Guerrero, J., Kastner, M., Kelts, K., Lyle, M., Matoba, Y., Molina-Cruz, A., Niemitz, J., Rueda, J., Saunders, A., Schrader, H., Simoneit, B., and Vacquier, V., 1980. Intrusion of basaltic sills into highly porous sediments and resulting hydrothermal activity. Nature, 283:441-445.

Gieskes, J.M., Gamo, T., and Brumsack, H., 1991. Chemical methods for interstitial water analysis aboard JOIDES Resolution. ODP Tech. Note, 15.

German, C.R., Barreiro, B.A., Higgs, N.C., Nelsen, T.A., Ludford, E.M., and Palmer, M.R., 1995. Seawater-metasomatism in hydrothermal sediments (Escanaba Trough, northeast Pacific). Chem. Geol., 119:175-190.

Grassle, J.F., and Petrecca, R., 1994. Soft-sediment hydrothermal vent communities of Escanaba Trough. In Morton, J.L., Zierenberg, R.A., and Reiss, C.A. (Eds.), Geologic, Hydrothermal, and Biological Studies at Escanaba Trough, Gorda Ridge, Offshore Northern California. U.S. Geol. Surv. Bull., 2022:327-335.

Grimalt, J., and Albaiges, J., 1987. Sources and occurrence of $\mathrm{C}_{12}-\mathrm{C}_{22} n$ alkane distributions with even carbon-number preference in sedimentary environments. Geochim. Cosmochim. Acta, 51:1379-1384.

Hunt, J.M., 1996. Petroleum Geochemistry and Geology (2nd. ed): New York (W.H. Freeman and Company).

Karlin, R.E., and Morton, J.L., 1994. Crustal magnetization and basement structure of Escanaba Trough. In Morton, J.L., Zierenberg, R.A., and Reiss, C.A. (Eds.), Geologic, Hydrothermal, and Biologic Studies at Escanaba Trough, Gorda Ridge, Offshore Northern California. U.S. Geol. Surv. Bull., 2022:77-90.

Karlin, R.E., and Zierenberg, R.A., 1994. Sedimentation and neotectonism in the SESCA area, Escanaba Trough, southern Gorda Ridge. In Morton, J.L., Zierenberg, R.A., and Reiss, C.A. (Eds.), Geologic, Hydrothermal, and Biologic Studies at Escanaba Trough, Gorda Ridge, Offshore Northern California. U.S. Geol. Surv. Bull. 2022:131-142.

Kawka, O.E., and Simoneit, B.R.T., 1990. Polycyclic aromatic hydrocarbons in hydrothermal petroleums from the Guaymas Basin spreading center. In Simoneit, B.R.T. (Ed.), Organic Matter in Hydrothermal SystemsPetroleum Generation, Migration and Biogeochemistry. Appl. Geochem., 5:17-27.

Koski, R.A., Benninger, L.M., Zierenberg, R.A., and Jonasson, I.R., 1994. Composition and growth history of hydrothermal deposits in Escanaba Trough, Southern Gorda Ridge. In Morton, J.L., Zierenberg, R.A., and
Reiss, C.A. (Eds.), Geologic, Hydrothermal, and Biologic Studies at Escanaba Trough, Gorda Ridge, Offshore Northern California. U.S. Geol. Surv. Bull., 2022:293-324.

Koski, R.A., Shanks, W.C., III, Bohrson, W.A., and Oscarson, R.L., 1988. The composition of massive sulfide deposits from the sediment-covered floor of Escanaba Trough, Gorda Ridge: implications for depositional processes. Can. Mineral., 26:655-673.

Kvenvolden, K.A., Rapp, J.B., and Hostettler, F.D., 1994. Hydrocarbons in sediment from Escanaba Trough. In Morton, J.L., Zierenberg, R.A., and Reiss, C.A. (Eds.), Geologic, Hydrothermal, and Biologic Studies at Escanaba Trough, Gorda Ridge, Offshore Northern California, U.S. Geol. Surv. Bull., 2022:279-292.

Kvenvolden, K.A., Rapp, J.B., Hostettler, F.D., Morton, J.L., King, J.D., and Claypool, G.E., 1986. Petroleum associated with polymetallic sulfide in sediment from the Gorda Ridge. Science, 243:1231-1234.

Kvenvolden, K.A., and Simoneit, B.R.T., 1990. Hydrothermally derived petroleum: examples from Guaymas Basin, Gulf of California and Escanaba Trough, Northeast Pacific Ocean. AAPG Bull., 74:223-237.

Magenheim, A.J., and Gieskes, J.M., 1994. Evidence for hydrothermal flow through surficial sediments in the Guaymas basin, Gulf of California and the Escanaba Trough. In Morton, J.L., Zierenberg, R.A., and Reiss, C.A. (Eds.), Geologic, Hydrothermal, and Biologic Studies at Escanaba Trough, Gorda Ridge, Offshore Northern California. U.S. Geol. Surv. Bull., 2022:241-256.

McCollom, T.M., Simoneit, B.R.T., and Shock, E.L., in press. Reactivity of monocyclic aromatic compounds in hydrothermal experiments and geologic fluids. Geochim. Cosmochim. Acta.

Morton, J.L., Holmes, M.L., and Koski, R.A., 1987. Volcanism and massive sulfide formation at a sedimented spreading center, Escanaba Trough, Gorda Ridge, northeast Pacific Ocean. Geophys. Res. Lett., 14:769-772.

Morton, J.L., Zierenberg, R.A., and Reiss, C.A., 1994. Geologic, hydrothermal, and biologic studies at Escanaba Trough: an introduction. In Morton, J.L., Zierenberg, R.A., and Reiss, C.A. (Eds.), Geologic, Hydrothermal, and Biologic Studies at Escanaba Trough, Gorda Ridge, Offshore Northern California. U.S. Geol. Surv. Bull., 2022:1-18.

Niemitz, J.W., 1982. Geochemistry of sediments, Leg, 64, Gulf of California. In Curray, J.R., Moore, D.G., et al., Init. Repts. DSDP, 64 (Pt. 2): Washington (U.S. Govt. Printing Office), 695-713.

Normark, W.R., Gutmacher, C.E., Zierenberg, R.A., Wong, F.L., and Rosenbauer, R.J., 1994. Sediment fill of Escanaba Trough. In Morton, J.L., Zierenberg, R.A., and Reiss, C.A. (Eds.), Geologic, Hydrothermal, and Biologic Studies at Escanaba Trough, Gorda Ridge, Offshore Northern California. U.S. Geol. Surv. Bull., 2022:91-130.

Peter, J.M., and Scott, S.D., 1988. Mineralogy, composition, and fluid-inclusion microthermometry of seafloor hydrothermal deposits in the southern trough of Guaymas Basin, Gulf of California. Can. Mineral., 26:567587.

Ross, S.L., Klitgord, K.D., Reid, J.A., and Zierenberg, R.A., 1996. Recent sidescan imagery of NESCA site at Escanaba Trough, southern Gorda Ridge. Eos, 77:F316.

Ross, S.L., and Zierenberg, R., 1994. Volcanic geomorphology of SESCA and NESCA sites, Escanaba Trough. In Morton, J.L., Zierenberg, R.A., and Reiss, C.A. (Eds.), Geologic, Hydrothermal, and Biologic Studies at Escanaba Trough, Gorda Ridge, Offshore Northern California. U.S. Geol. Surv. Bull., 2022:143-152.

Shipboard Scientific Party, 1992. Site 858. In Davis, E.E., Mottl, M.J., Fisher, A.T., et al., Proc. ODP, Init. Repts., 139: College Station, TX (Ocean Drilling Program), 431-569.

Simoneit, B.R.T., 1977. Diterpenoid compounds and other lipids in deep-sea sediments and their geochemical significance. Geochim. Cosmochim. Acta, 41:463-476.

1978. The organic chemistry of marine sediments. In Riley, J.P., and Chester, R. (Eds.), Chemical Oceanography (2nd ed.) (Vol. 7): New York (Academic Press), 233-311.

, 1984. Hydrothermal effects on organic matter-high versus low temperature components. In Schenck, P.A., deLeeuw, J.W., and Lijmbach, G.W.M. (Eds.), Advances in Organic Geochemistry 1983: Oxford (Pergamon Press), 857-864.

, 1985. Hydrothermal petroleum: genesis, migration and deposition in Guaymas Basin, Gulf of California. Can. J. Earth Sci., 22:1919-1929.

(Ed.), 1990. Organic matter in hydrothermal systems-maturation, migration and biogeochemistry. Appl. Geochem., 5:1-248.

, 1994. Lipid/bitumen maturation by hydrothermal activity in sediments of Middle Valley, Leg 139. In Mottl, M.J., Davis, E.E., Fisher, 
A.T., and Slack, J.F. (Eds.), Proc. ODP, Sci. Results, 139: College Station, TX (Ocean Drilling Program), 447-465.

Simoneit, B.R.T., Brenner, S., Peters, K.E., and Kaplan, I.R., 1981. Thermal alteration of Cretaceous black shale by basaltic intrusions in the eastern Atlantic. II: Effects on bitumen and kerogen. Geochim. Cosmochim. Acta, 45:1581-1602.

Simoneit, B.R.T., and Fetzer, J.C., 1996. High molecular weight polycyclic aromatic hydrocarbons in hydrothermal petroleums from the Gulf of California and Northeast Pacific Ocean. Org. Geochem., 24:1065-1077.

Simoneit, B.R.T., Goodfellow, W.D., and Franklin, J.M., 1992. Hydrothermal petroleum at the seafloor and organic matter alteration in sediments of Middle Valley, northern Juan de Fuca Ridge. Appl. Geochem., 7:257264.

Simoneit, B.R.T., Kawka, O.E., and Brault, M., 1988. Origin of gases and condensates in the Guaymas Basin hydrothermal system (Gulf of California). Chem. Geol., 71:169-182.

Simoneit, B.R.T., Prahl, F.G., Leif, R.N., and Mao, S.-Z., 1994. Alkenones in sediments of Middle Valley, Leg 139: application as thermal sensors. In Mottl, M.J., Davis, E.E., Fisher, A.T., and Slack, J.F. (Eds.), Proc. ODP, Sci. Results, 139: College Station, TX (Ocean Drilling Program), 479484.

Spivack, A.J., Palmer, M.R., and Edmond, J.M., 1987. The sedimentary cycle of the boron isotopes. Geochim. Cosmochim. Acta, 51:1939-1949.
Tissot, B.P., and Welte, D.H., 1984. Petroleum Formation and Occurrence (2nd ed.): Heidelberg (Springer-Verlag).

Vallier, T.L., Harold, P.J., and Girdley, W.A., 1973. Provenances and dispersal patterns of turbidite sand in Escanaba Trough, northeastern Pacific Ocean. Mar. Geol., 1:67-87.

Zierenberg, R.A., Koski, R.A., Morton, J.L., Bouse, R.M., and Shanks, W.C., III, 1993. Genesis of massive sulfide deposits on a sediment-covered spreading center, Escanaba Trough, $41^{\circ} \mathrm{N}$, Gorda Ridge. Econ. Geol., 88:2069-2098

Zierenberg, R.A., Morton, J.L., Koski, R.A., and Ross, S.L., 1994. Geologic setting of massive sulfide mineralization in the Escanaba Trough. In Morton, J.L., Zierenberg, R.A., and Reiss, C.A. (Eds.), Geologic, Hydrothermal, and Biologic Studies at Escanaba Trough, Gorda Ridge, Offshore Northern California. U.S. Geol. Surv. Bull., 2022:171-197.

Zierenberg, R.A., and Shanks, W.C., III, 1994. Sediment alteration associated with massive sulfide formation in Escanaba Trough, Gorda Ridge: the importance of seawater mixing and magnesium metasomatism. In Morton, J.L., Zierenberg, R.A., and Reiss, C.A. (Eds.), Geologic, Hydrothermal, and Biologic Studies at Escanaba Trough, Gorda Ridge, Offshore Northern California. U.S. Geol. Surv. Bull., 2022:257-278.

Ms 169IR-106

NOTE: For all sites drilled, core-description forms ("barrel sheets") and core photographs can be found in Section 3, beginning on page 299. Smear-slide data and thin-section data can be found on CD-ROM. See Table of Contents for material contained on CD-ROM. 


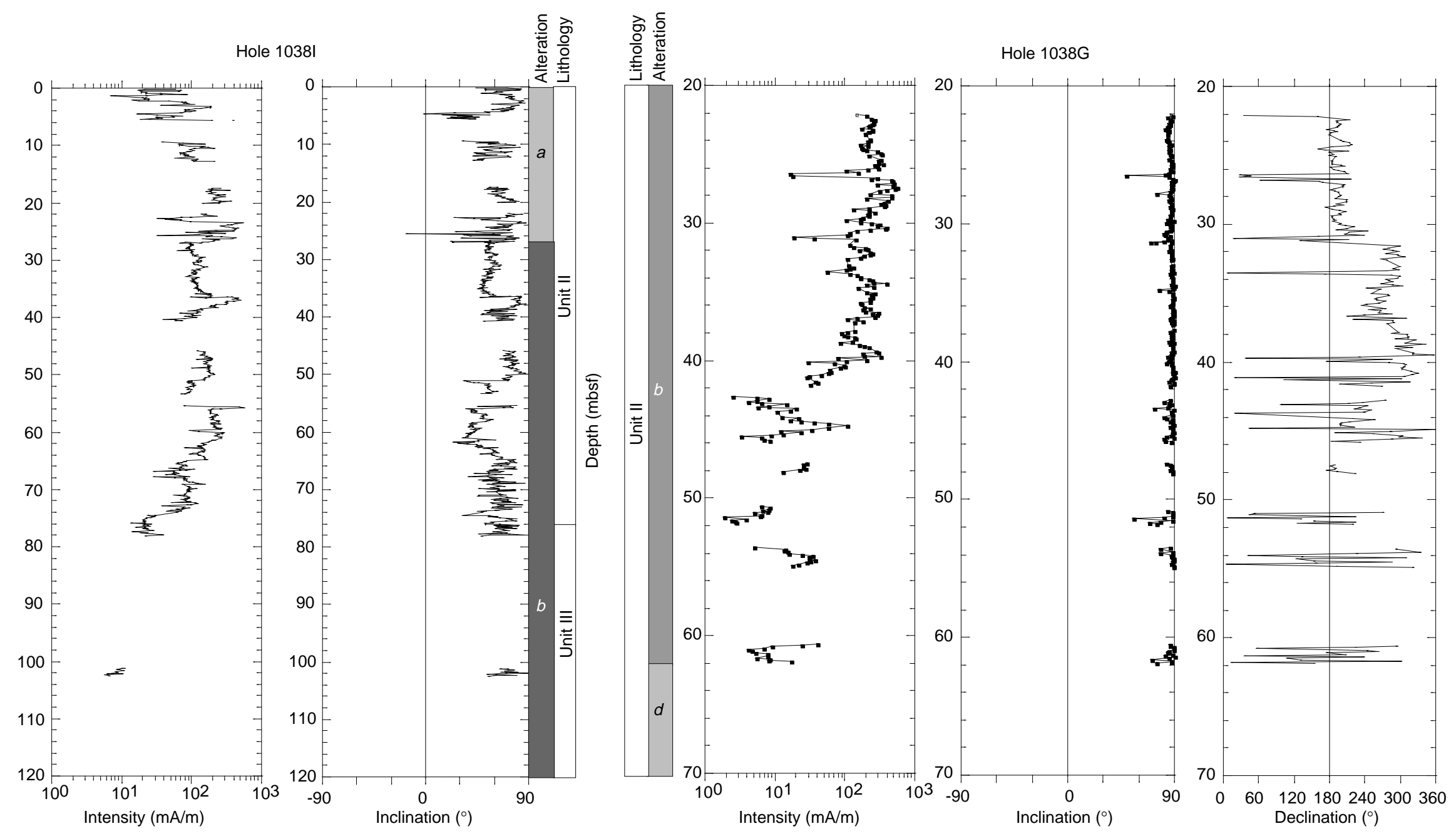

Figure 48. Magnetic intensity, inclination, and declination after 20-mT demagnetization of cores from Holes 1038G and 1038I. Declinations are not oriented with respect to geographic north, and only reflect relative rotations among continuous intervals of core. Columns in the center summarize general lithological characteristics and assigned alteration facies of cores from Holes $1038 \mathrm{I}$ and $1038 \mathrm{G}$ (see "Lithostratigraphy and Sedimentology" section, this chapter). Also note the different depth scales.

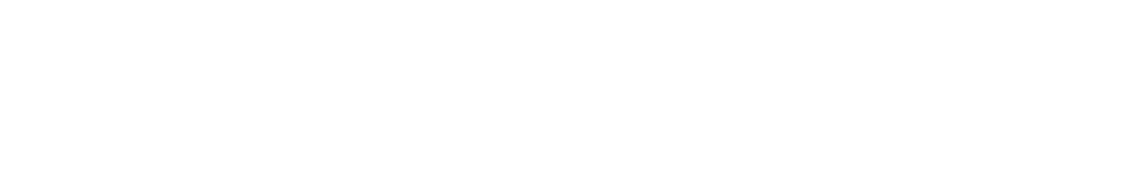

